\title{
فعالية برنامج تدريبي قائم على استفدام الفيديو التفاعلى في تنمية بعض مهارات القراءة والكتابة لدى ذوي صعوبات التعلم
}

الدكتورة/ أميرة السيل مسعود السيل

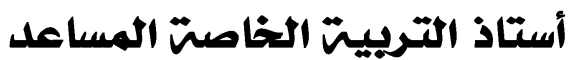
جامعت القصيه - المملكت العربيت السعوديت 


$$
\text { ملخص البحث }
$$

هدف البحث الحالى إلى تنميتت مهارات القـراءة والكتابتَّ باستختد اهر الفيـديو

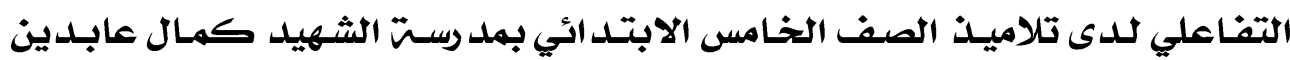

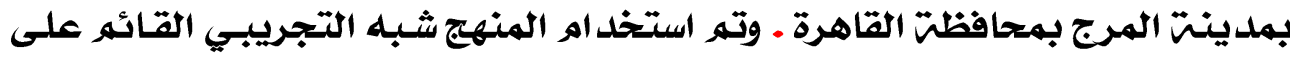

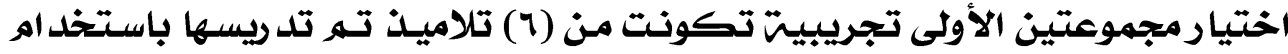

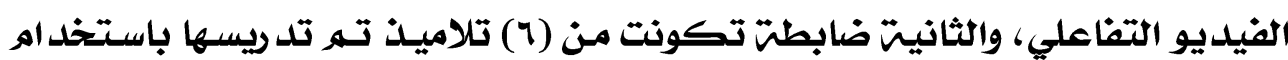

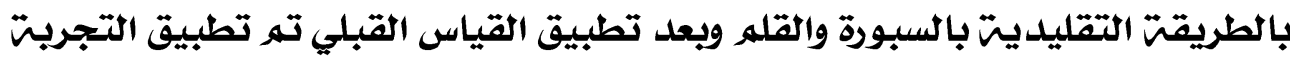

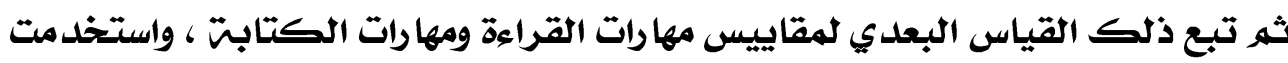

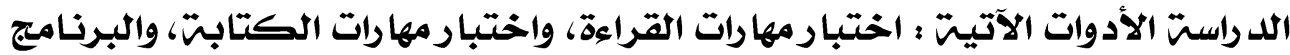

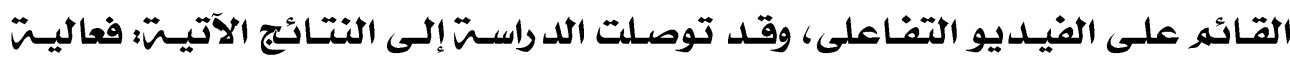

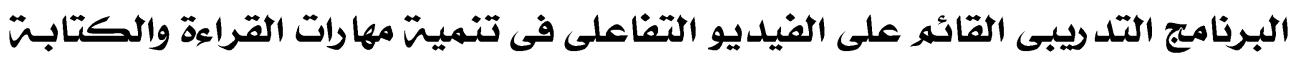

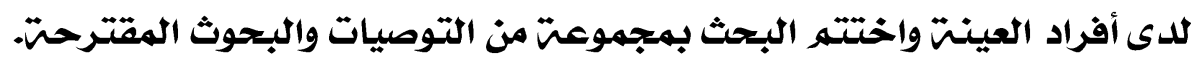

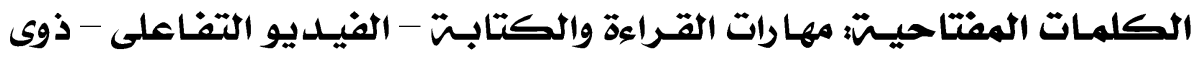

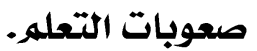




\begin{abstract}
The aim of the current research is to develop reading and writing skills using the interactive video of fifth grade primary pupils at Al-Shahid Kamal Abdin School in a school in Cairo governorate. Two groups of two groups of two experimental groups of (6) students were taught using the interactive video, and the second was a control that consisted of (6) students who were taught using the traditional method with a blackboard and pen. After applying the measurement, the experiment was applied and then the measurement followed that measurement. The study used the following skills: a reading skills test, a writing skills test, and an interactive video-based program, and the study reached the following results: The effectiveness of the interactive video-based training program in reading and writing development is effective.
\end{abstract}

.Keywords: Reading and Writing Skills - Interactive video People with Learning Disabilities 
مقدمتر:

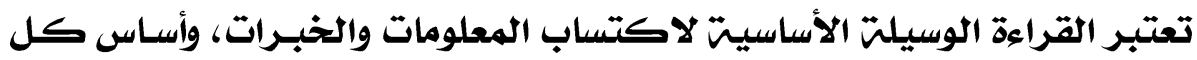

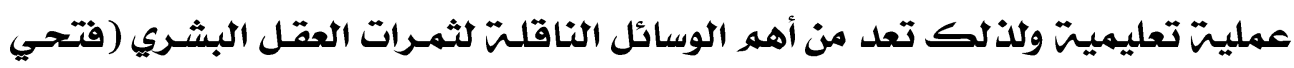

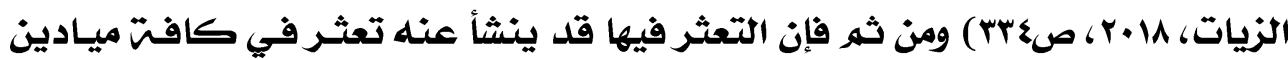

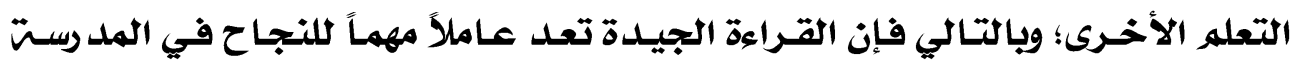

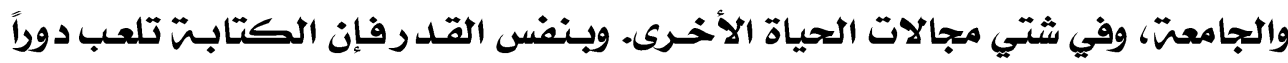

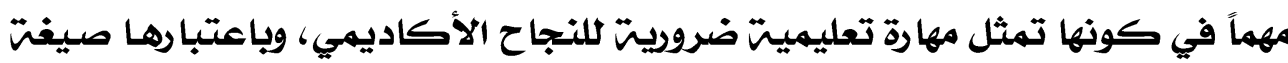

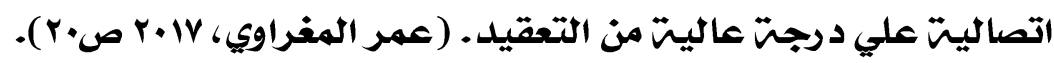

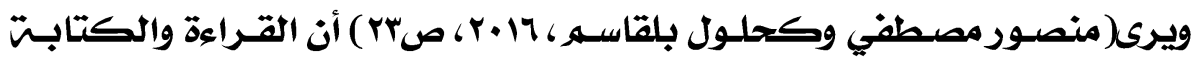
تتجاوزان حلدود الإدراك البصري للرموز المكتوبتت إلى حلها وفهـه معانيها ، والنطق

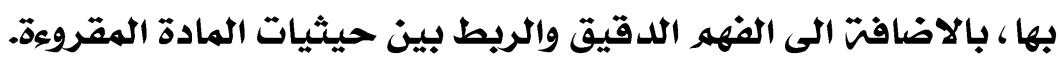

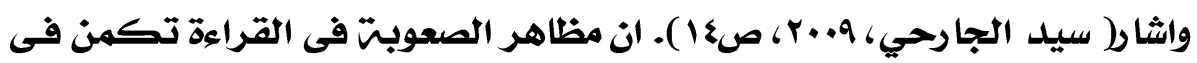

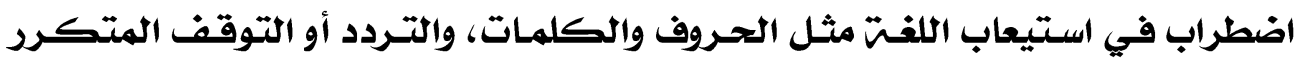

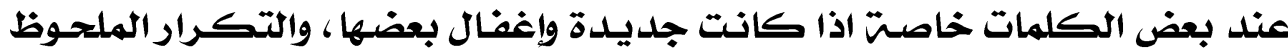

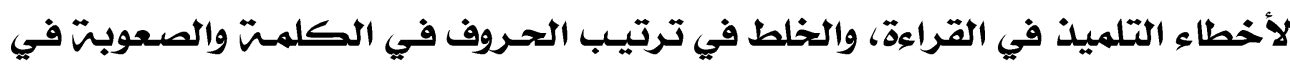

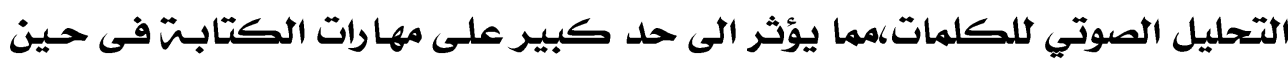

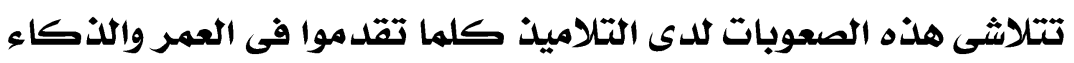

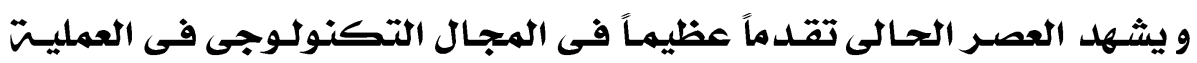

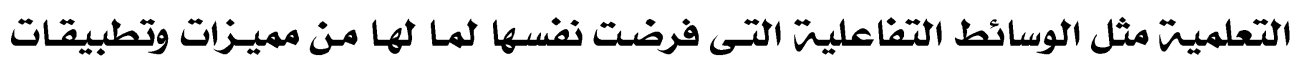

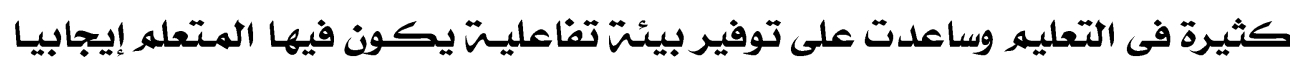

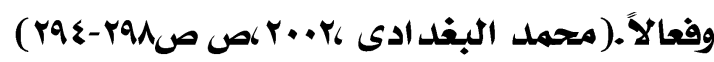

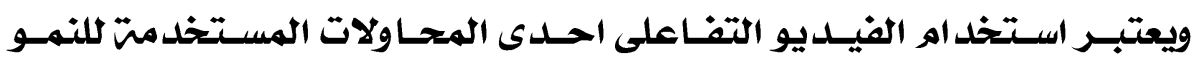

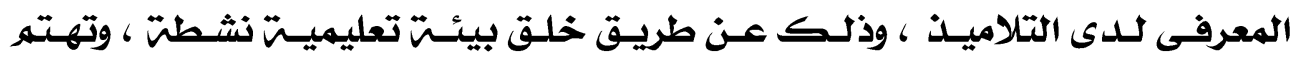

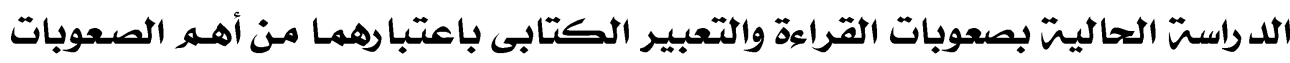

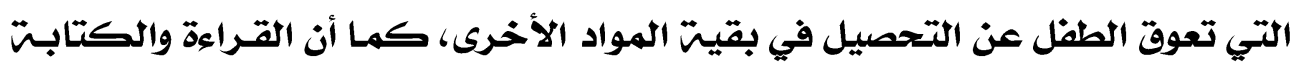

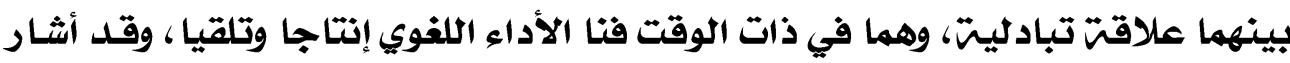

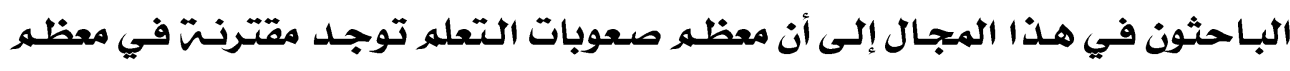

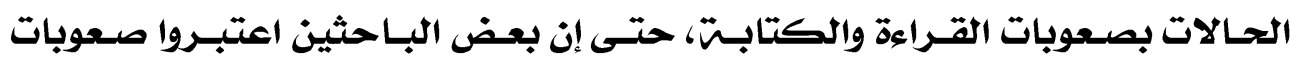

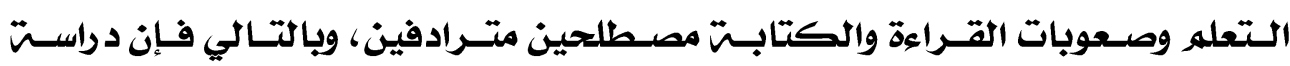

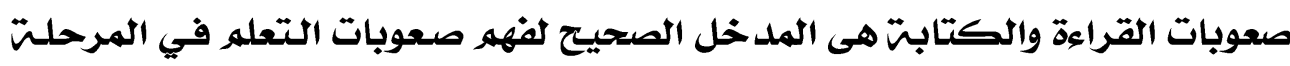

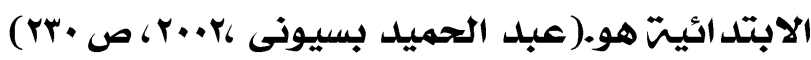


مشكلت البحث:

إن التلاميذ ذوى صعوبات التعله فى حاجت شديلدة الى استخداهر التكنولوجيا

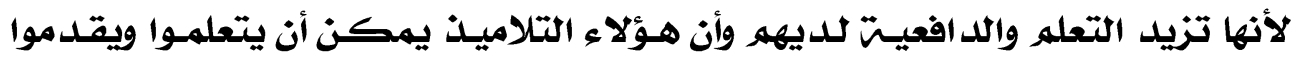

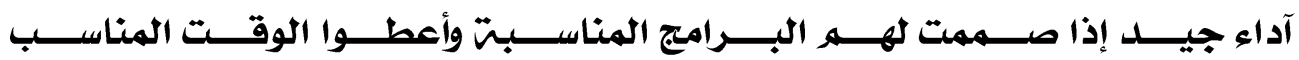
(Badian,2005,P30)

كـذلك أكـد البـاحثثون على اهميـت الإسـراع فى تنميـت قـد رات الأطفنال

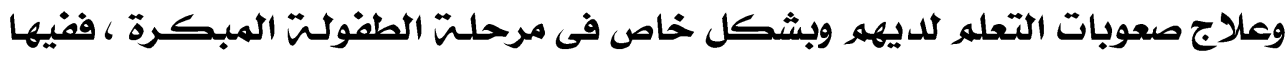

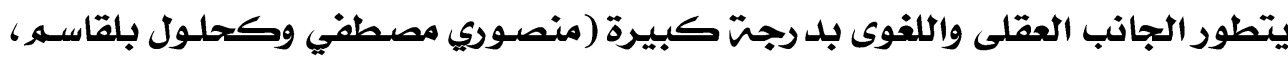

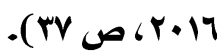

ومن المهارات الأساسيتيت التـي تهته بها منـاهج اللغتت العربيـت مهارات القـراءة

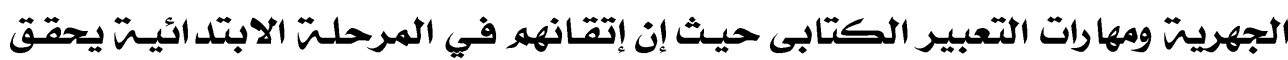

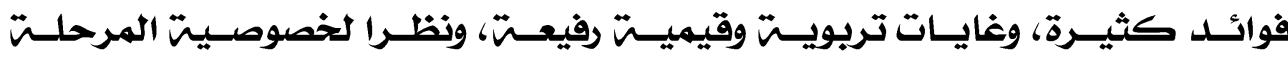

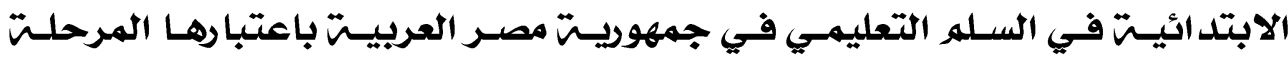

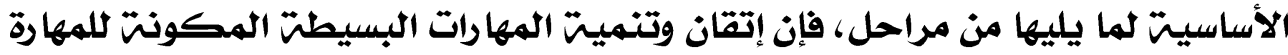

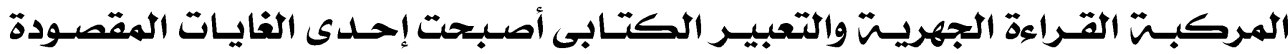

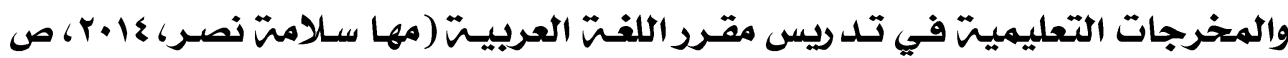

ولتحقيـق الأهــــاف المنشــودة والغايـات المقصــودة بمجــال مهـارات القــراءة والكتابـت تـه توظيف التقنيـت الحديثت وأبرزهـا بمجـال القـراءة الجهريـت الفيـديو

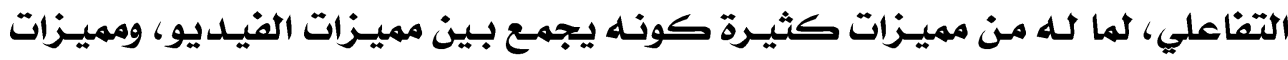

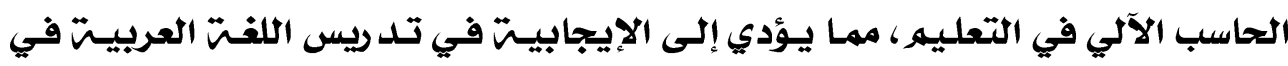

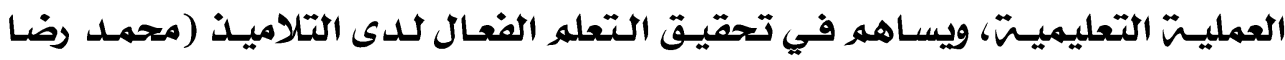

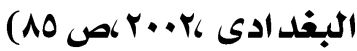
وتري الباحثت عده وجود برامج وسائط متعددة تفاعليت قائمت على استخد اهو

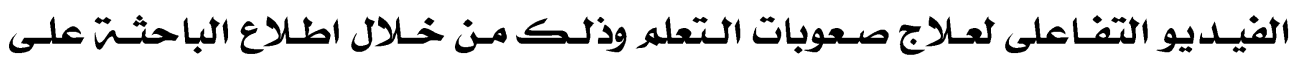

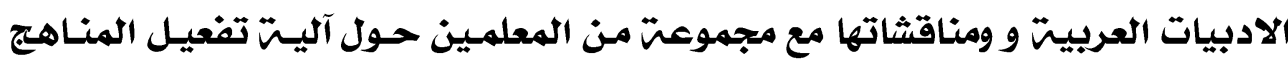

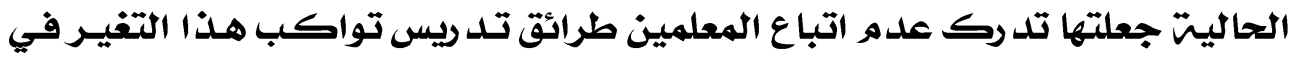

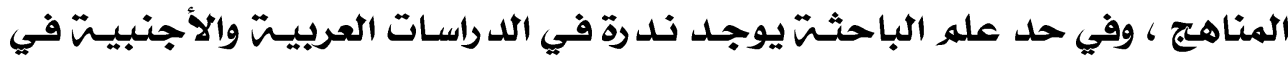

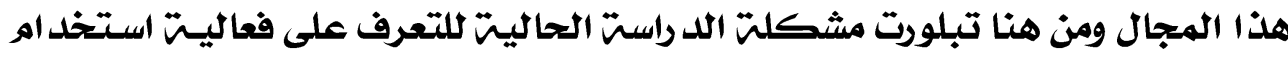

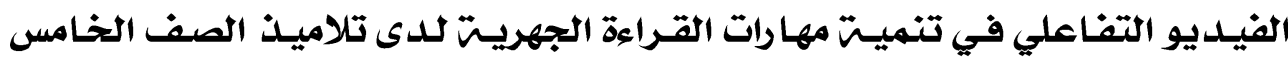

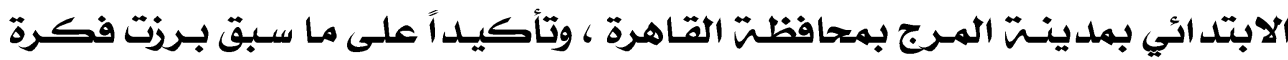

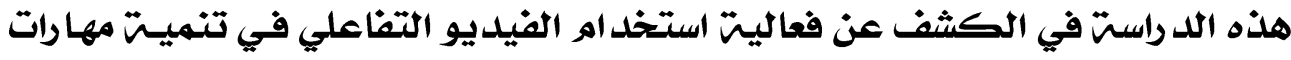


القـراءة والكتابـت للدى تلاميـذ الصف الخـامس الابتـد ائي بمل رستـت الشهيد كمهال

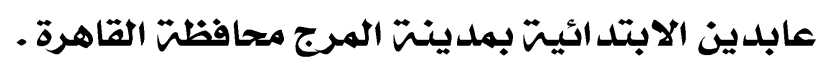

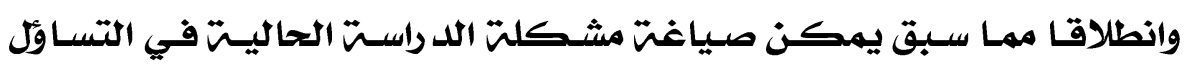

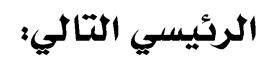

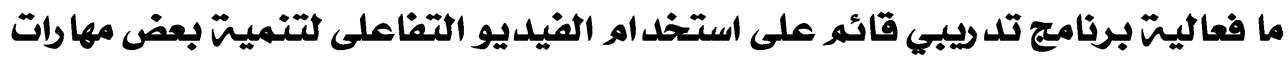

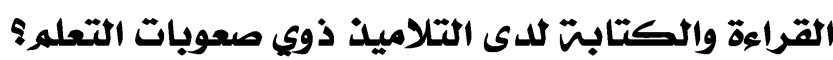

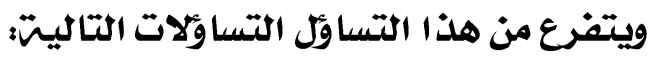

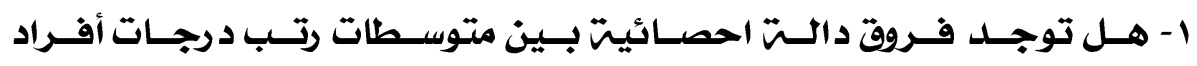

المجموعتين التجريبيتت والضابطت في الاختبار البعدي على مقياس مهارات القراءة ؟

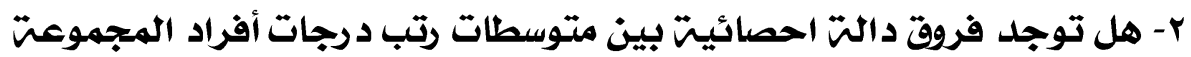

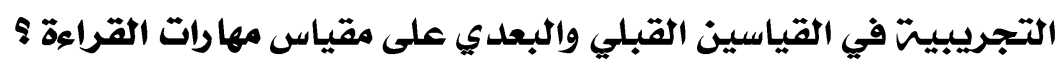

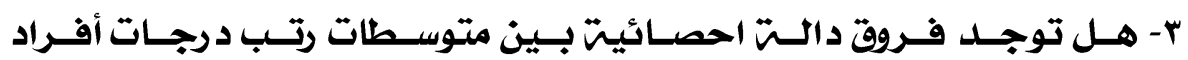

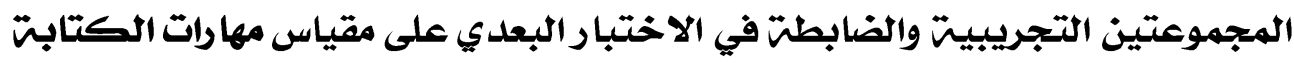

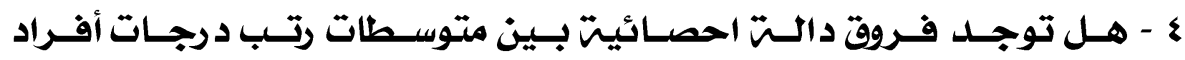

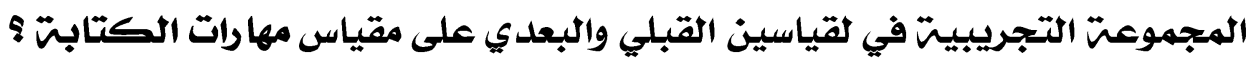

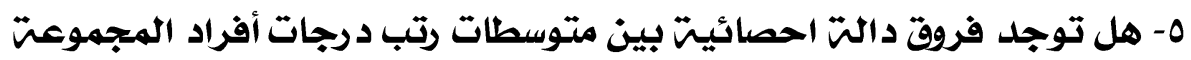

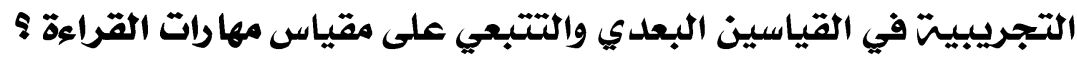

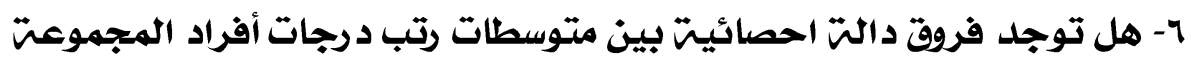

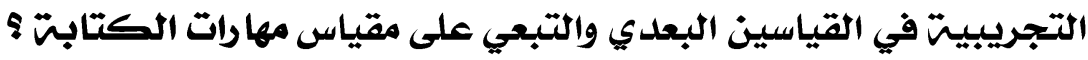

$$
\text { أهد اف البحث: }
$$

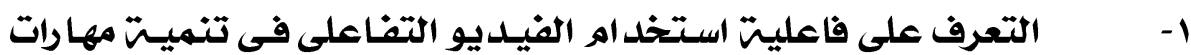

القراءة والكتابت لدى تلاميذ ذوي صعوبات التعله

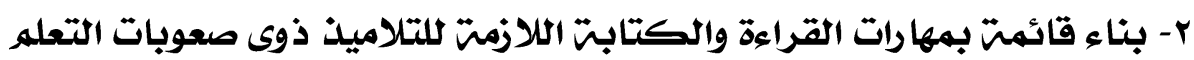

$$
\text { في مادة اللغت العربيتُ }
$$

r- الكشف عن تنميت مهارات القراءة والكتابت باستخد اهر الفيـديو التفناعلى

$$
\text { لدى التالاميذ ذوى صعوبات التعله في مادة اللغت العربيته. }
$$

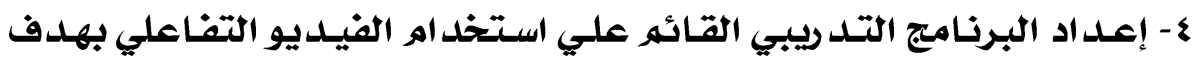

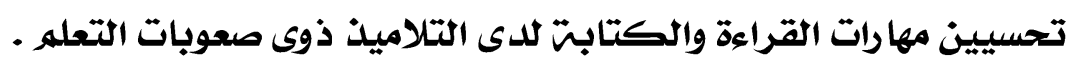




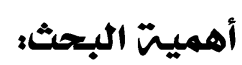

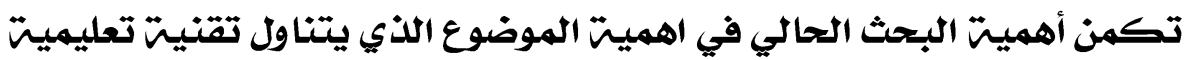

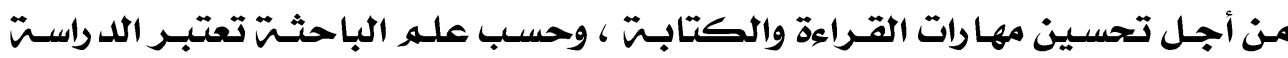

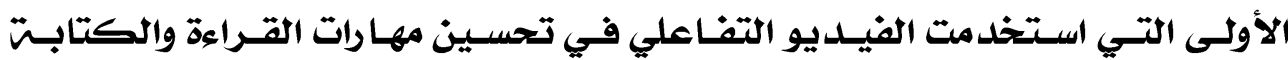
بالمرحلت الابتد ائيتة، وتحديد ا تكمن أهميت الد راست الحاليت فيما يلي:

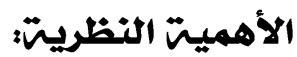

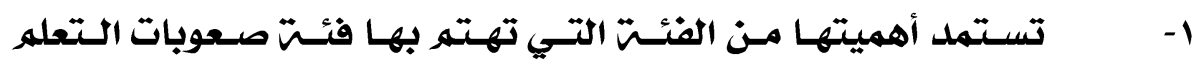

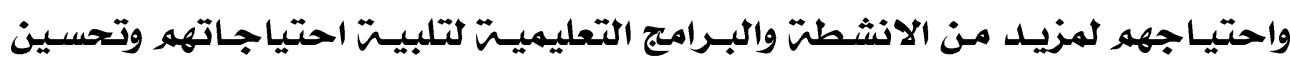
قد راتهه على التعله بشكل فعال.

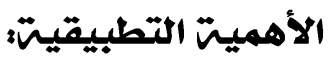

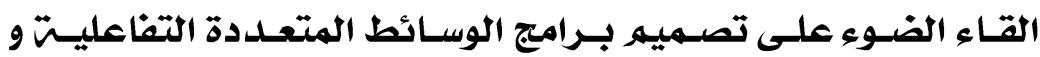
$-1$

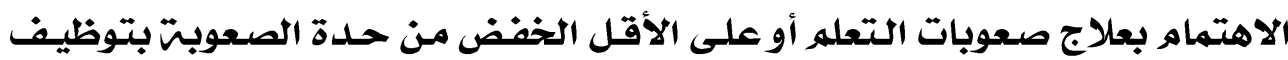
تكنولوجيا التعله

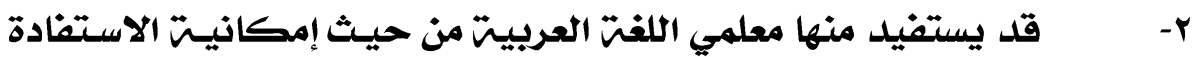
منها وتطبيقات الفيديو التفاعلي بالتد ريس.

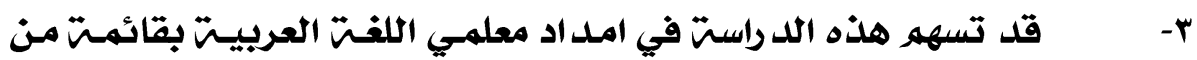

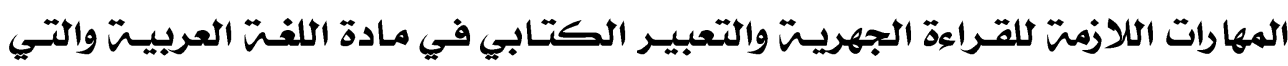

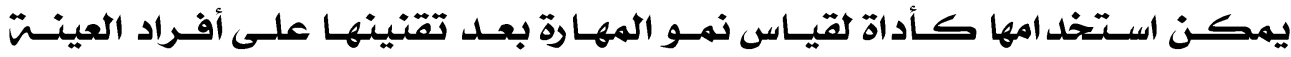

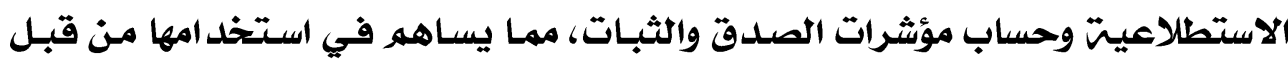
المعلمين أثناء التلد ريس. وحسئ.

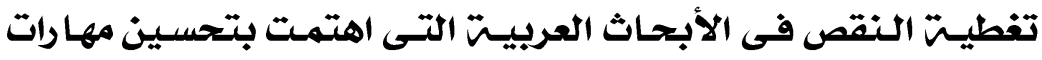
- ₹

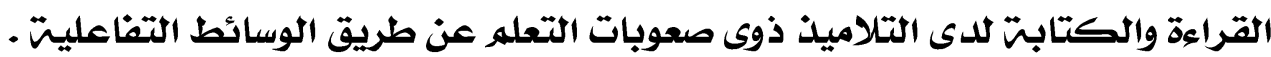

$$
\text { مفاهيمر البحث: }
$$

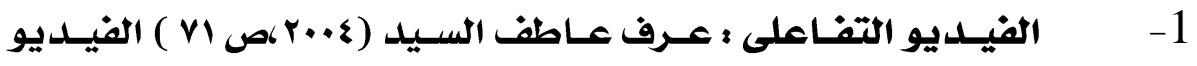

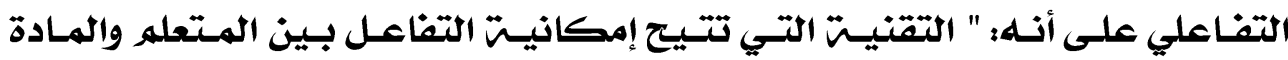

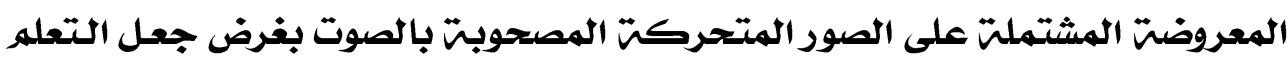

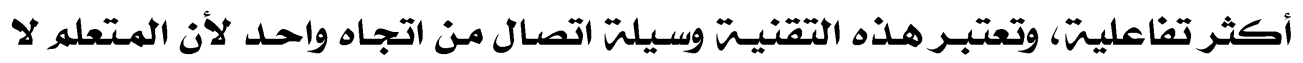

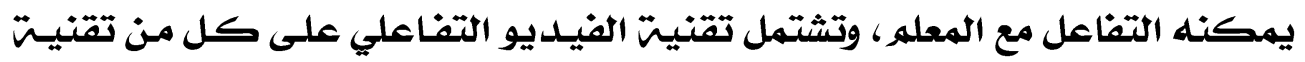

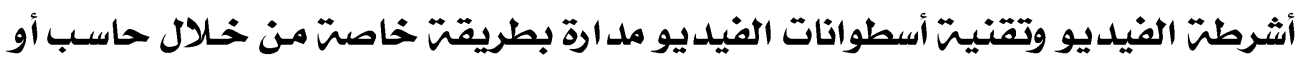

$$
\text { مستجل فيديو ". }
$$

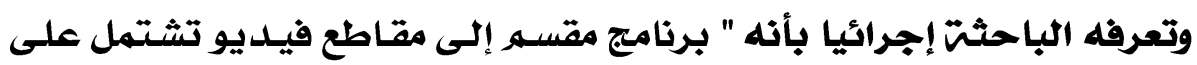

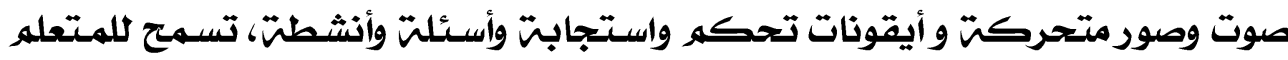
بالتحرك في البرنامج وفقا لسرعته وخطته وأهد اف البرنامجا. 


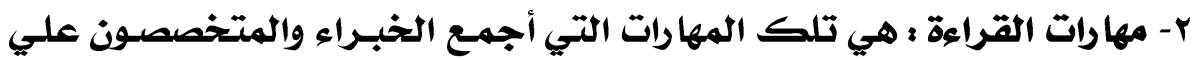

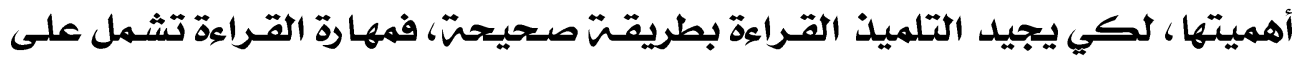

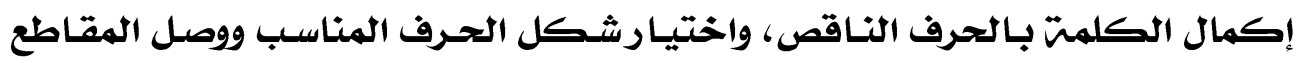

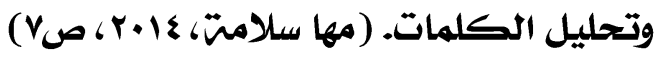

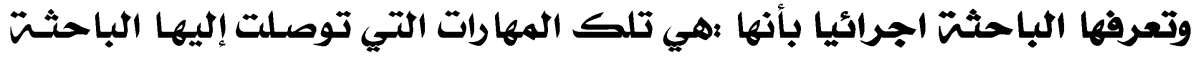

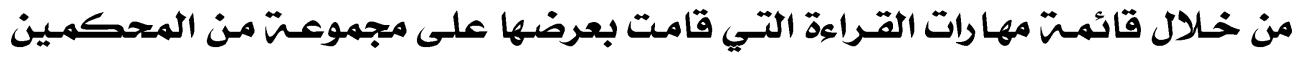

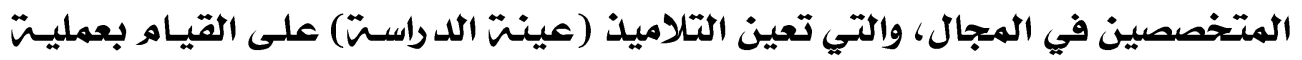

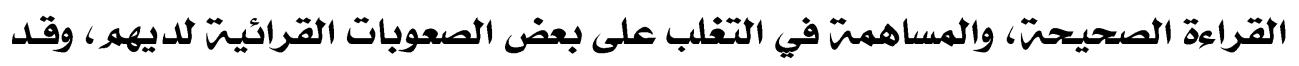

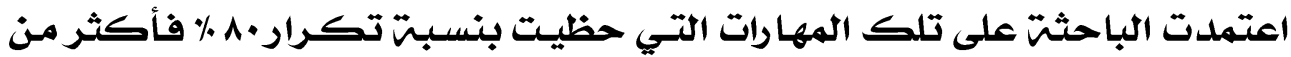

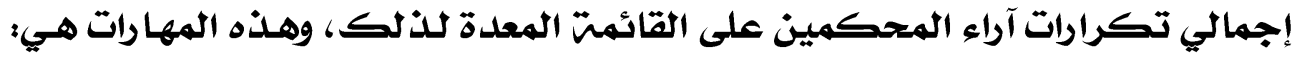

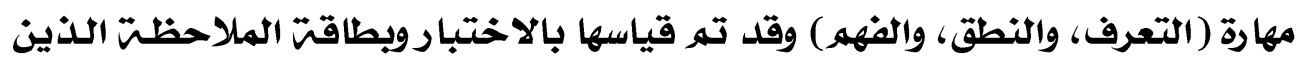

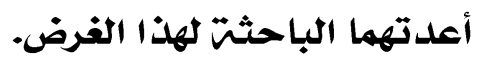

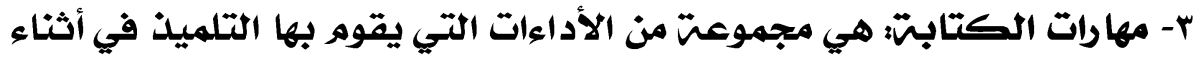

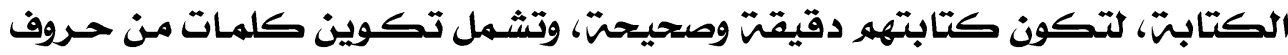
وإكمال العبارات وترتيـب الكلمـات والجمل وكتابـت ما يملـي عليـه. (محمدل فايز، .) $(\xi \cdot \pi+17$

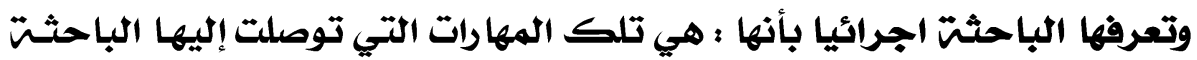

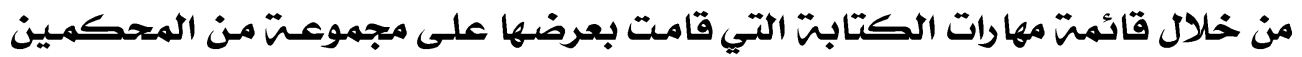
المتخصصين في المجال، والتي تعين التلاميذ (عينت الدراسـتة) على القيـاهر بعمليـته

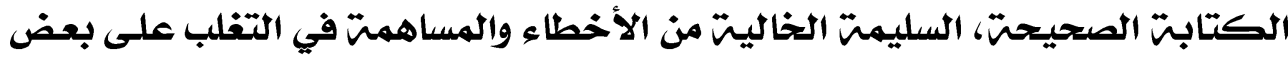

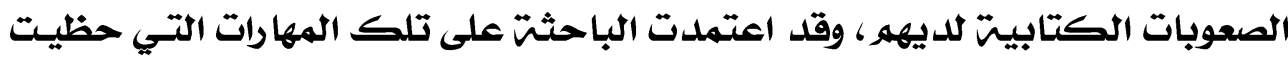

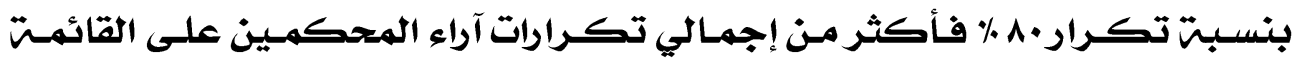

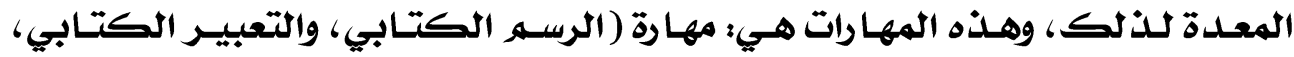
وجودة الكتابت) وقد ته قياسها بالاختبار الذي أعدته الباحثت لهذا الغرض.

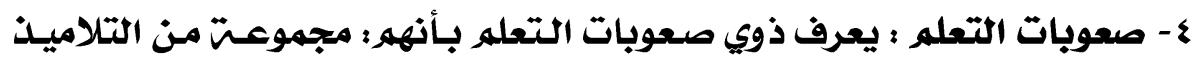

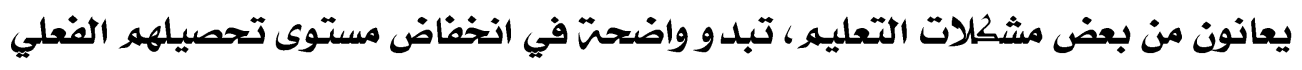

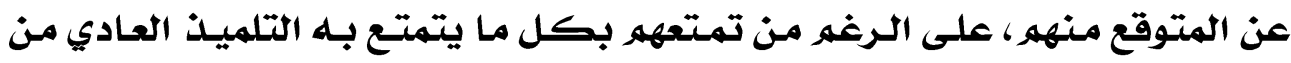
صفات، إلا أن لديهه صعوبت في بعض عمليات التعله في القراءة والكتابتت والحسـاب

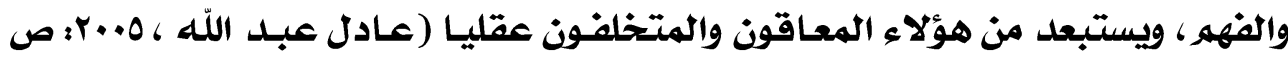

وتعرفها الباحثت اجرائيا بأنها : مصطلح يشير إلى مجموعت من التلاميذ داخل

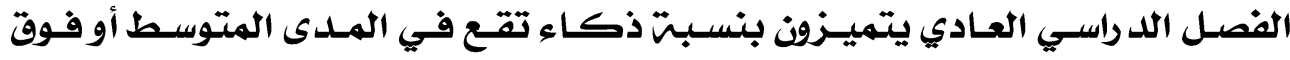
المتوسط، إلا أنهر يظهرون انخفاضـا دالا في الأداء الفعلي لمهارات القـراءة والتعبيـر 


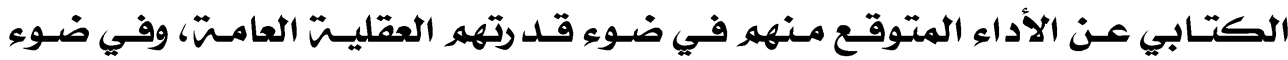

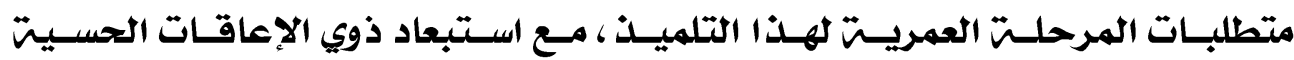

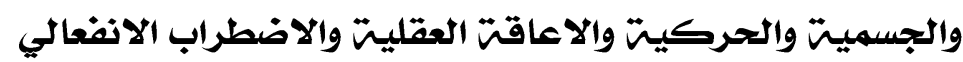

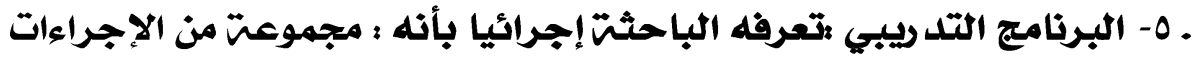

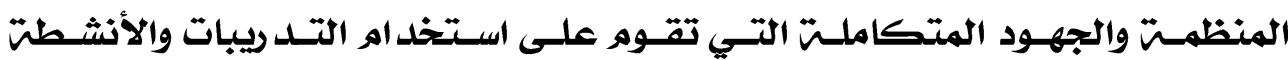

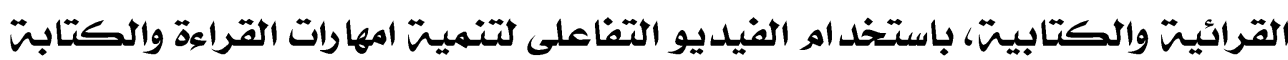
لدى اللتلاميذ ذوي صعوبات التعله محدد ات البحث:

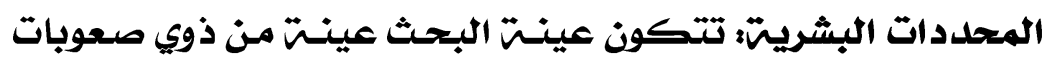

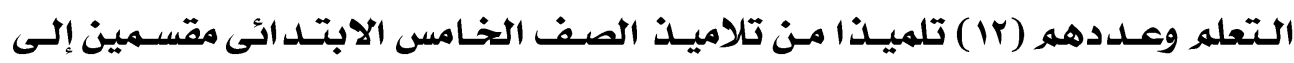
مجموعتين تجريبيت وضابطن وفئر

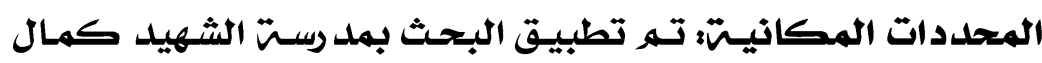

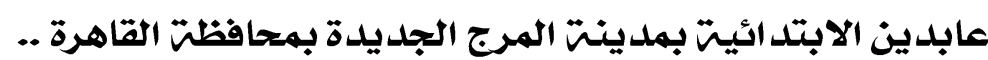

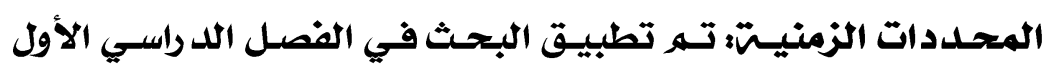

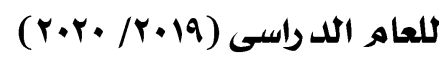

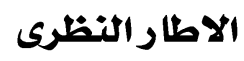

المحور الاول صعوبات القراءة :

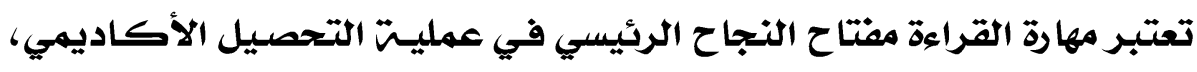

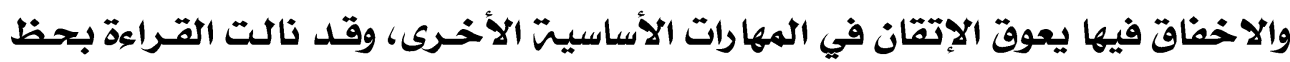

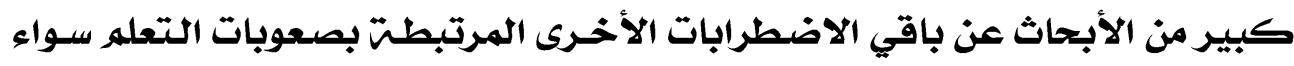

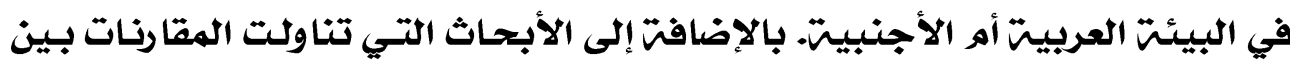

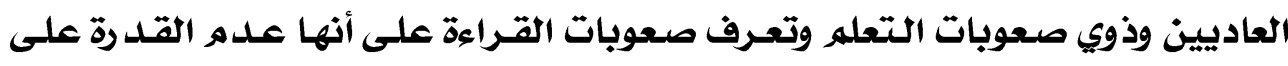

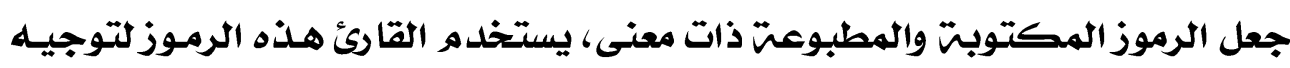

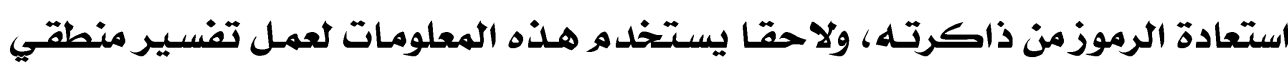
الرسالت الكاتب (Chard. D \& Dickson. 1999p265).

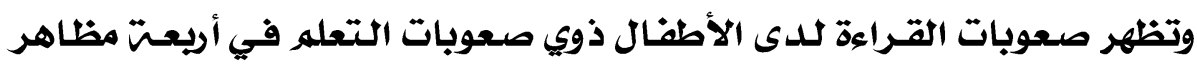

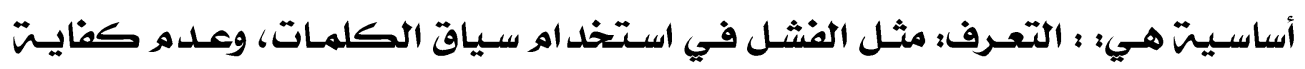

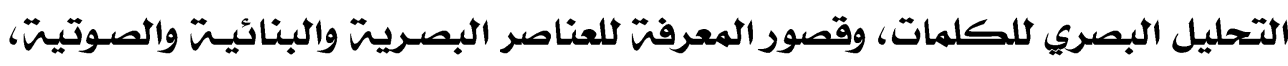

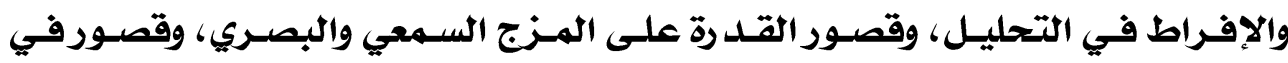

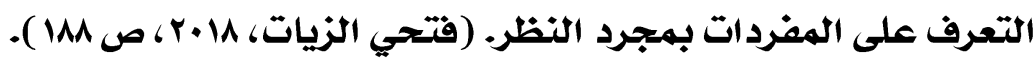


بالإضافت إلى أن الد راسات التي تقوه على صعوبات القراءة تمكن القـارئ مـن

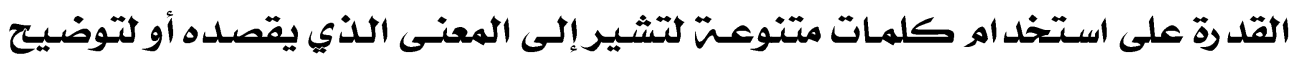

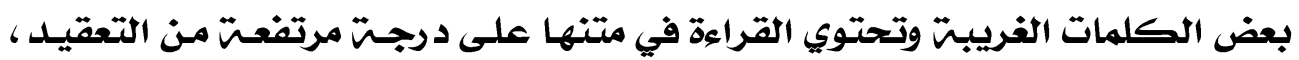

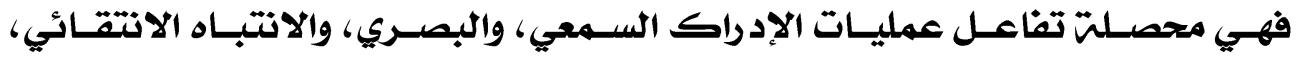

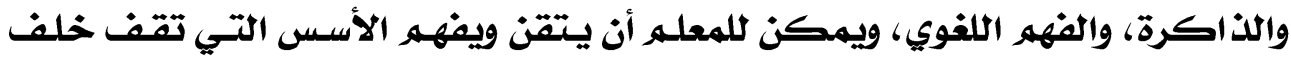

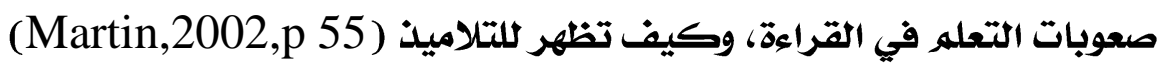

\section{المحور الثانى صعوبات الكتابتء:}

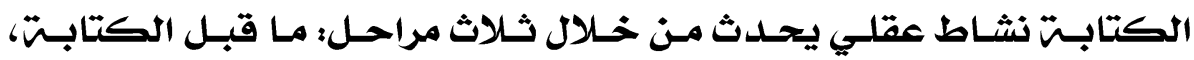

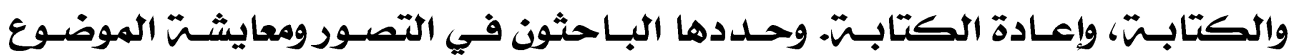

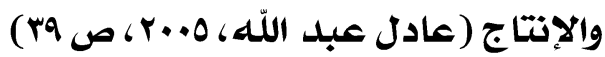

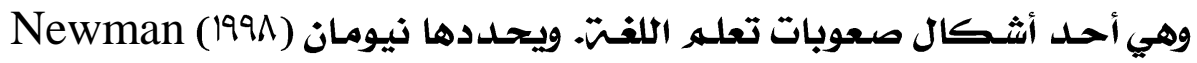

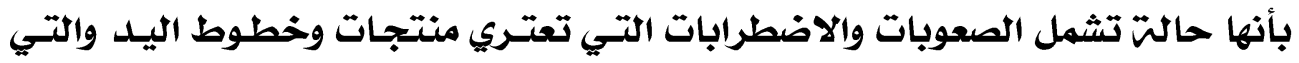

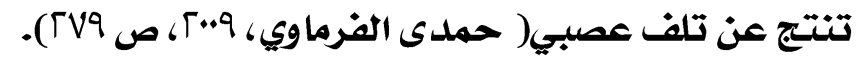

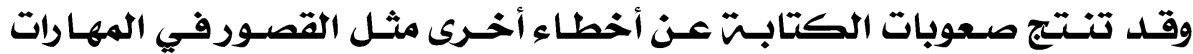

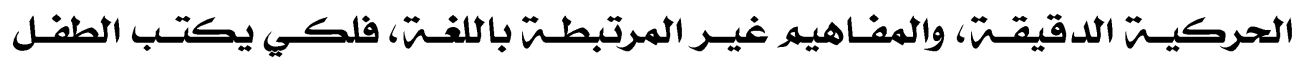

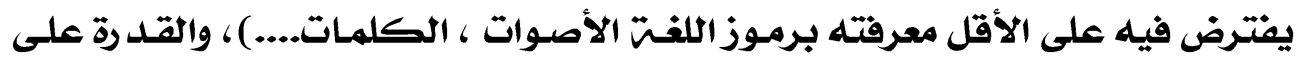

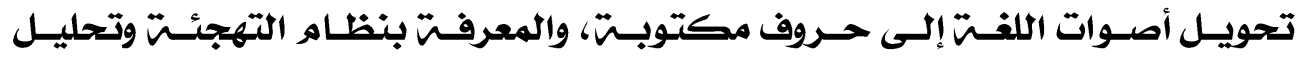

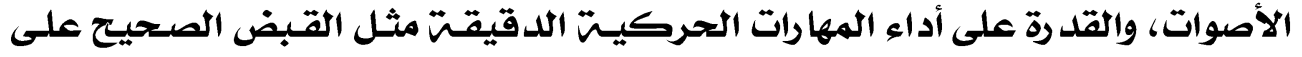

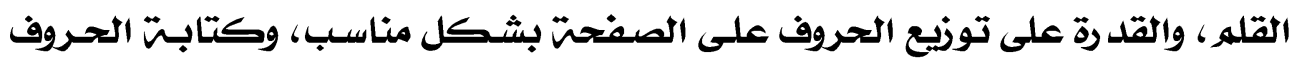

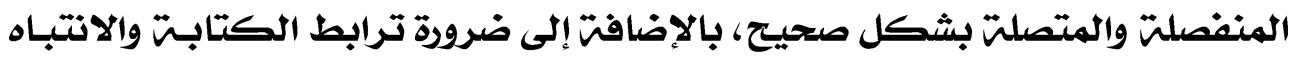

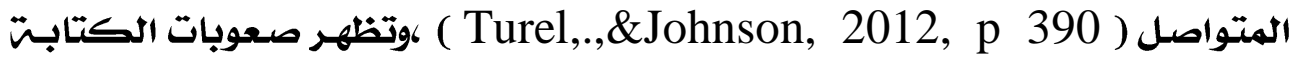
لدى الأطفال ذوبي صعوبات التعله في العديل من المظاهر التاليت:

مجهود كبير وبطء شليد يبذله الطفل أثناء الكتابتة، وكتابت الكلمات الكرات

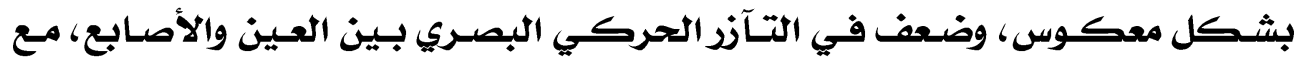

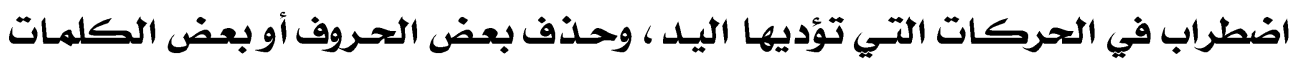

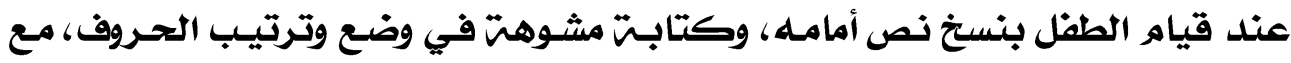

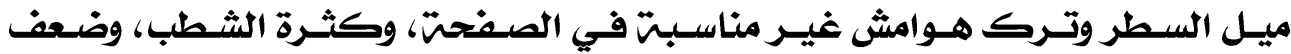

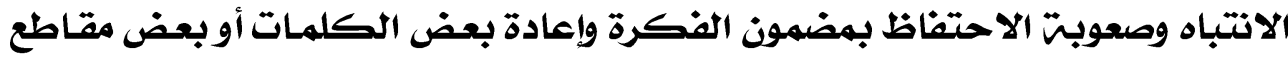

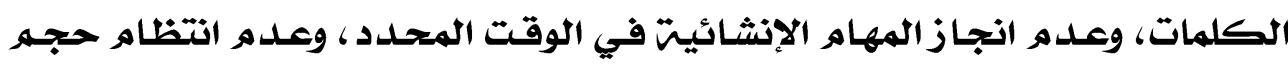

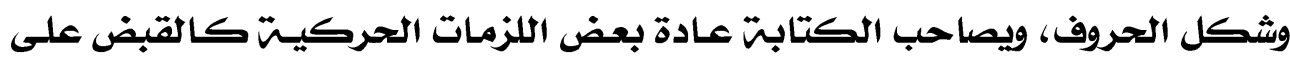

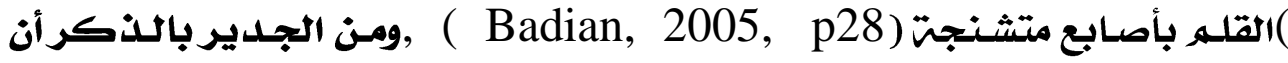

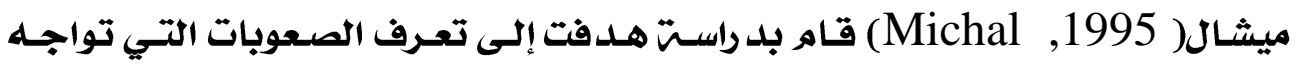




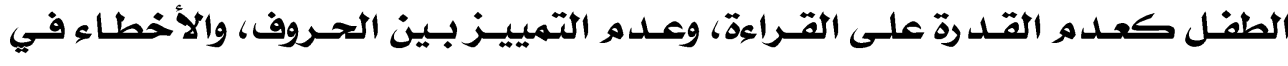

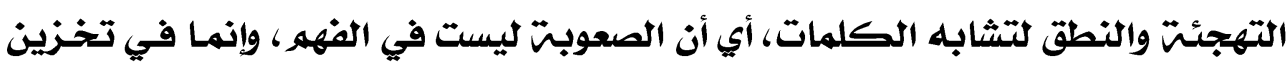

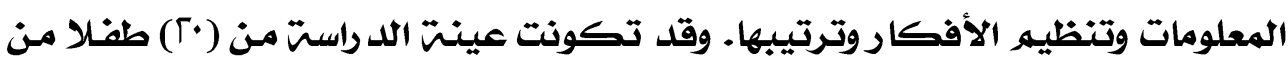

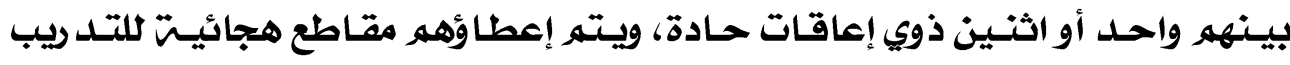

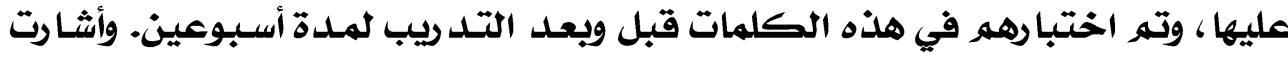

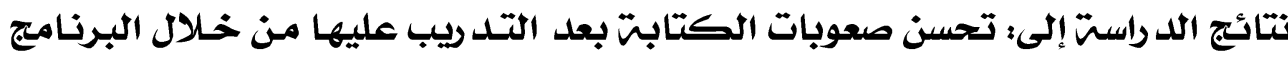

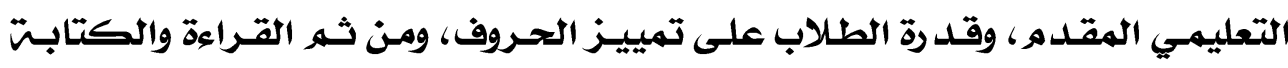
الجيدة.

وقد ذكر (Elizabeth. Nelson,E,2009,p 29)العديد من الأخطاء التي

يقع فيها الأطفال الذين يعانون من صعوبات تعلـه الكتابت بصـورة أكثر تفصيلا

كما يلي:

1- الحذف: ويتمثل في ترك كلمت في جملتش، أوحرف أو مقطع في كلمتة.

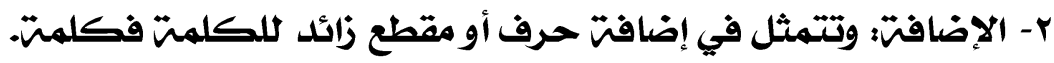

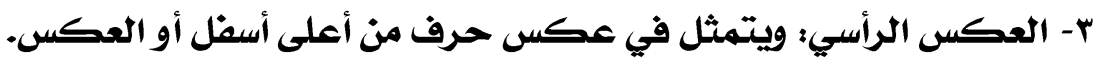

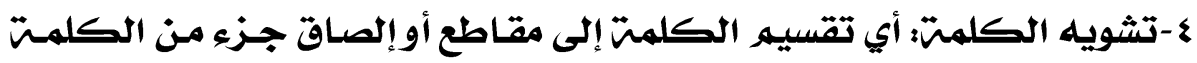
بالكلمت التاليته.

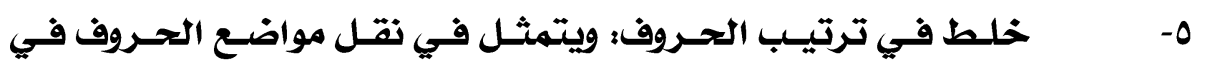

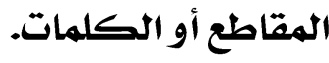

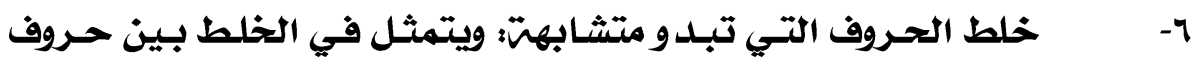

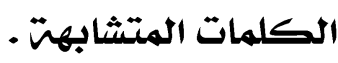

خلط الحروف التي تبدو أصواتها متشابهت: الخلط بـين الحـروف التـي $-v$ لها نفس النطق.

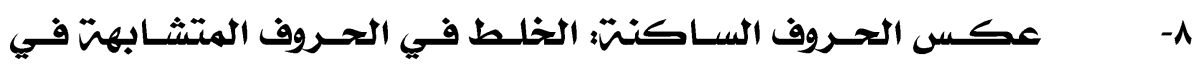
الشكل من حيث الاتجاه .

التلاحمات: وصل الكلمات وعلده ترك مسافت الكات بينها. $-9$ المحور الثالث الفيلديو التفاعلى :

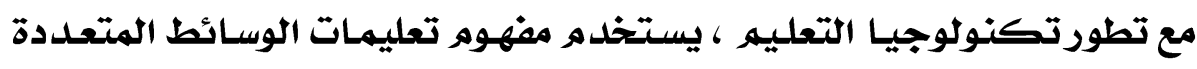

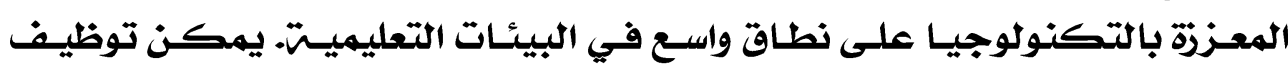

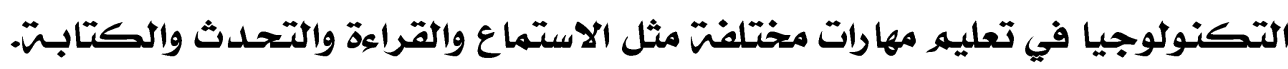

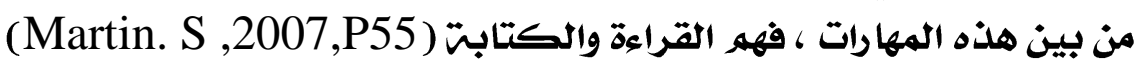

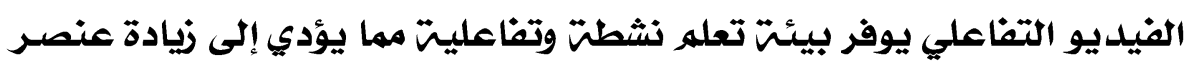

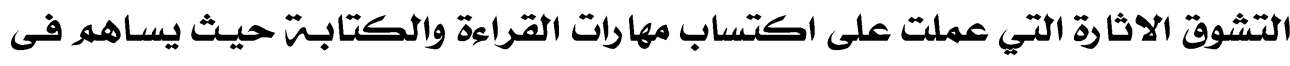

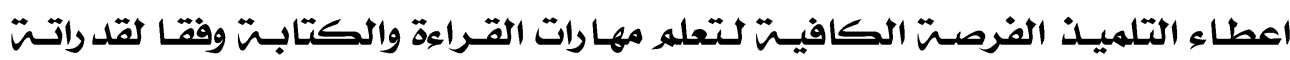




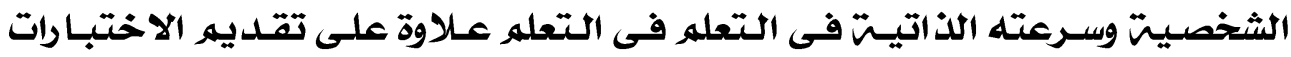

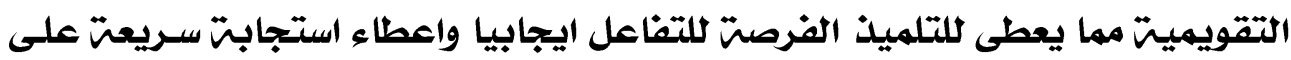

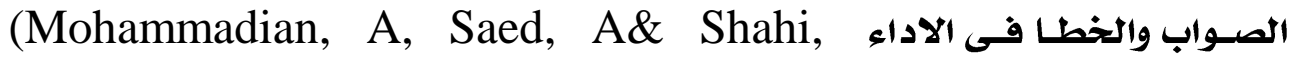

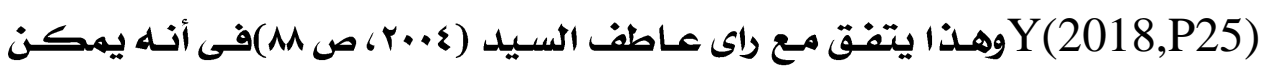

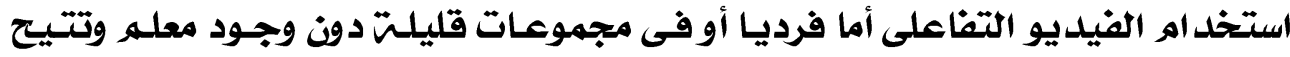

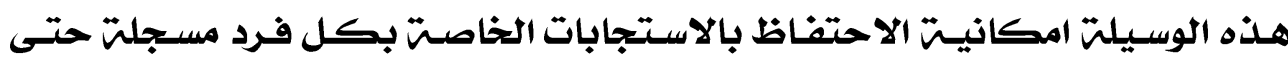

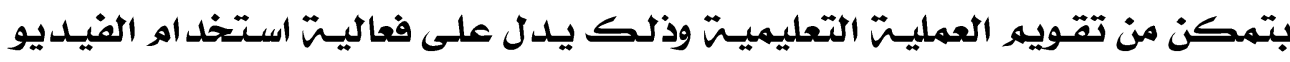

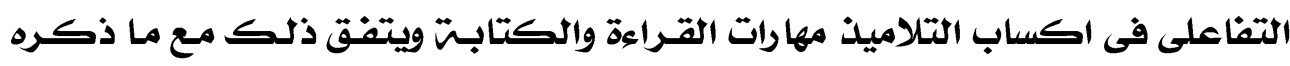

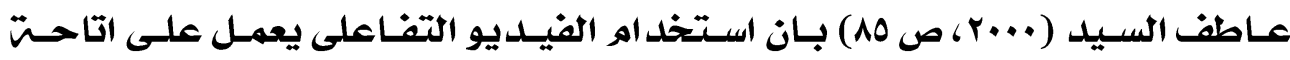

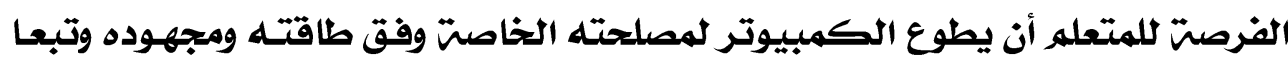

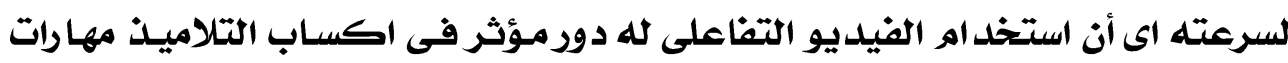

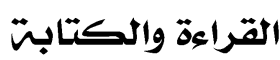

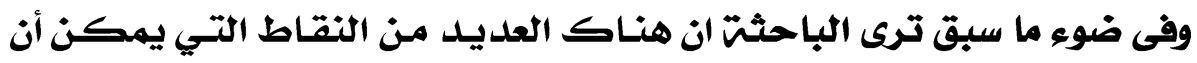

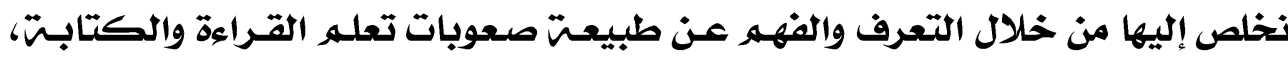

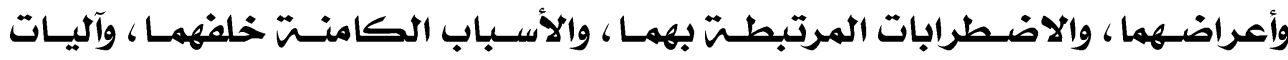

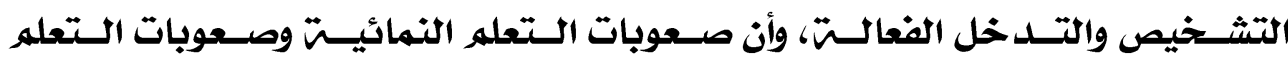

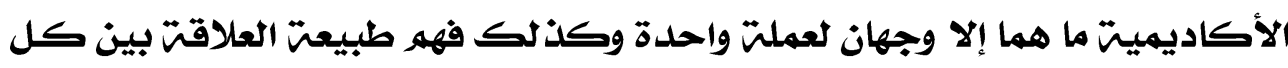

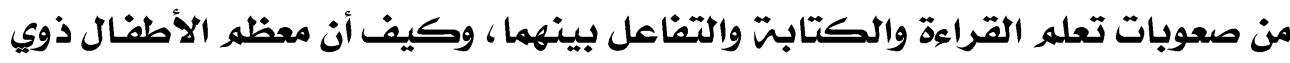

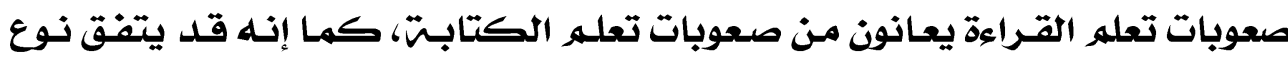

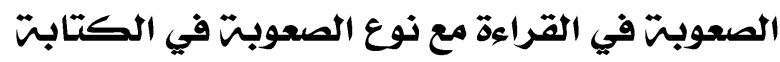

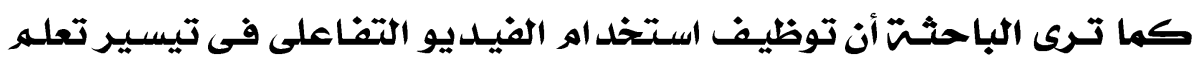

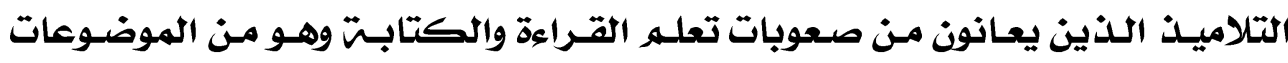

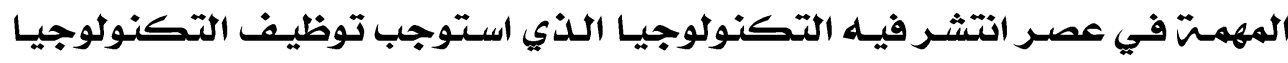

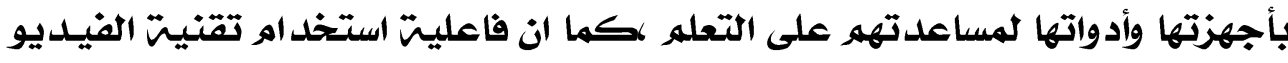

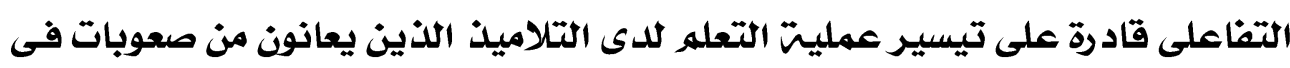

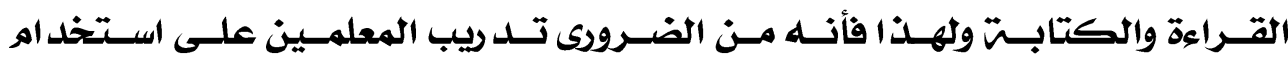

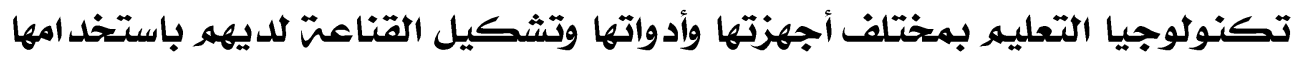

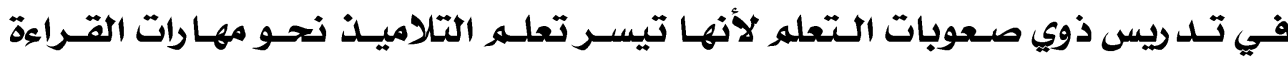

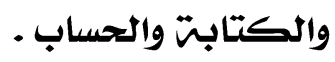

دراسات سابقن

تعرض الباحثت فى هذا المحور الد راسات والبحوث السابقت المتعلقت بمتغيرات

الد راست حيث تهو تصنيفهما الى محورين رئيسسين وهما 
المحسور الاول: دراسـات وبحـوث تناولت مهارات القـراءة والكتابـت لـلى ذوى

صعوبات التعلم

هدفت الد راستت التـي قاه بها ( Sucena , Castro \& Seymour 2009)

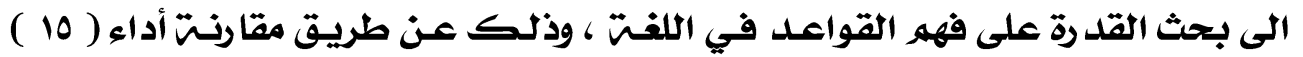

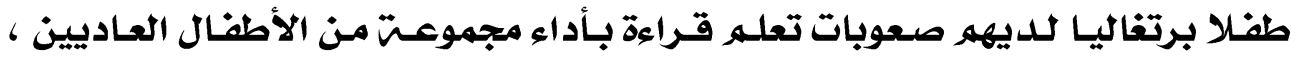

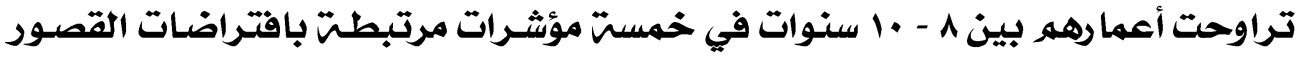

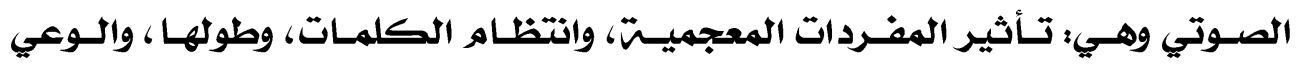

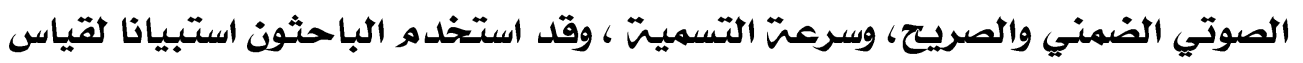

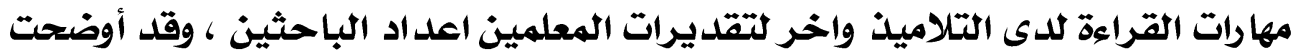

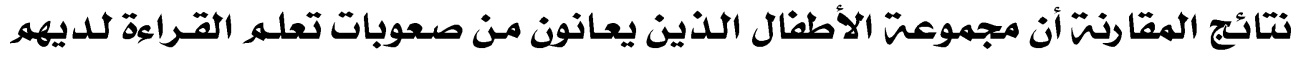

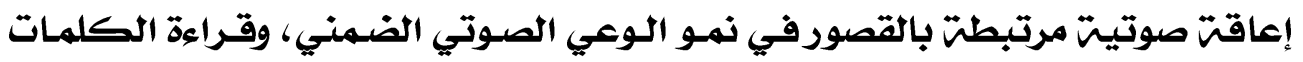

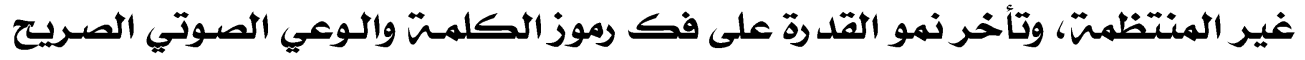
مقارنت بهجموعت القراء العاديين .

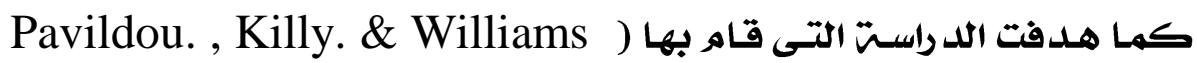

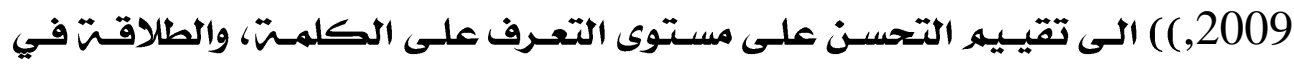

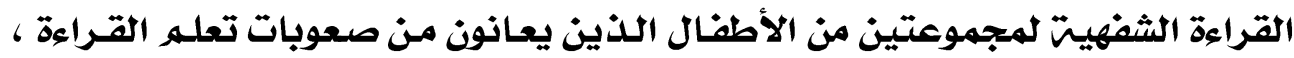

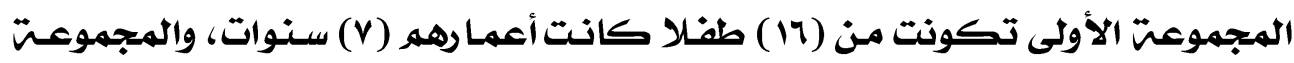

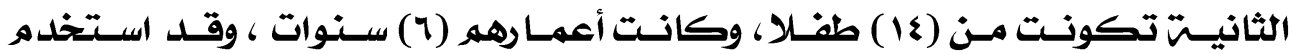
الباحثون بطاريت تقييهر الإدراك الصـوتي للتعرف على الطلاب ذوي صعوبات تعلـه

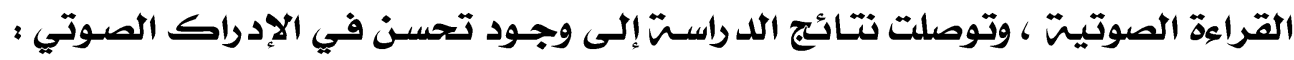

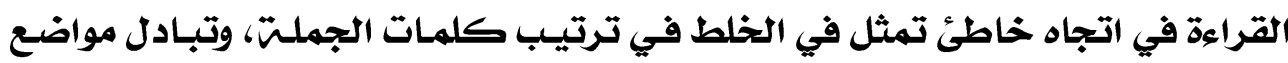

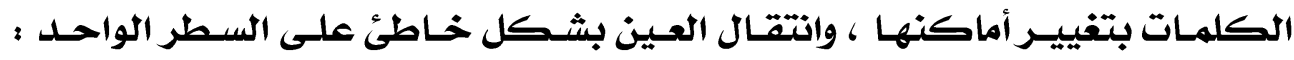

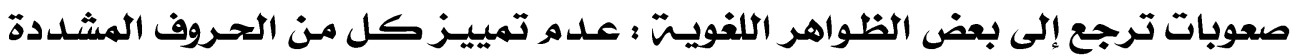

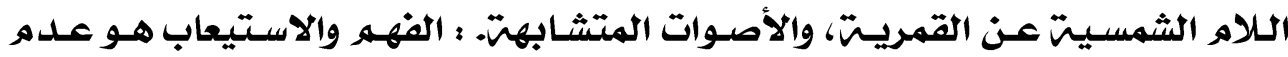

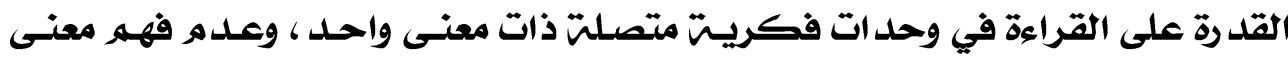

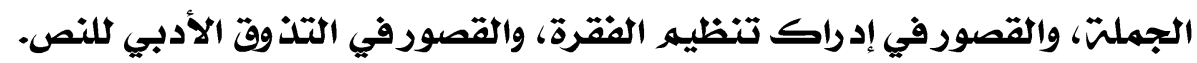

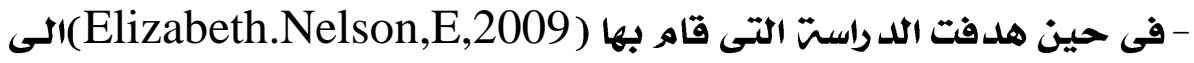

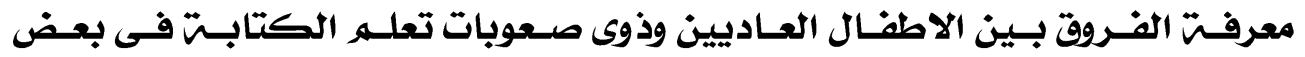

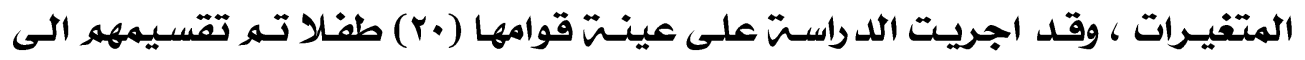

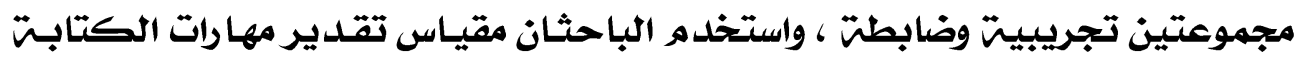

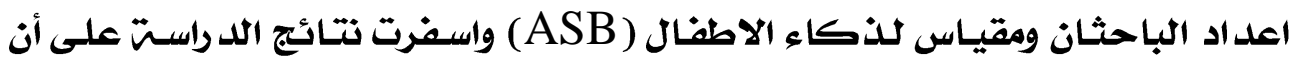

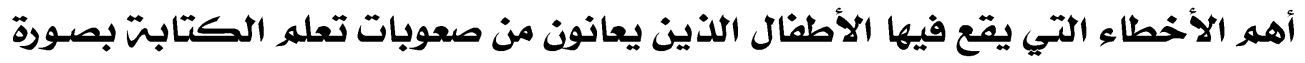
أكثر تفصيلا كما يلي: 
1- الحذف: ويتمثل في ترك كلمت في جملتة، أوحرف أو مقطع في كلمتة.

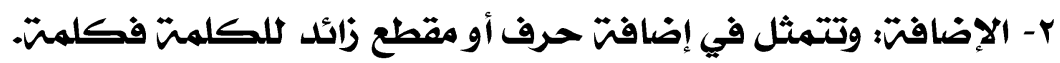

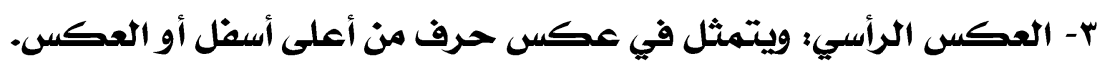

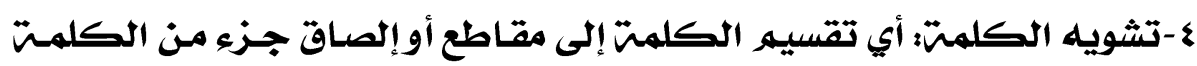
بالكلمت التاليتش.

ه- خلط في ترتيـب الحـروف: ويتمثل في نقل مواضع الحـروف في المقاطع أو الكلمات.

7-خلط الحروف التي تبدو متثابهت: ويتمثل في الخلط بين حـروف الكلمـات المتشابهن V-خلط الحروف التي تبلدو أصواتها متثابهت: الخلط بين الحروف التي لها نفس النطق. ^-عكس الحروف الساكنتّ: الخلط في الحروف المتشابهت في الشكل من

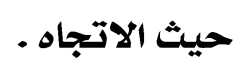

9- التلاحمات: وصل الكلمات و وعلده ترك مسافتّ بينها.

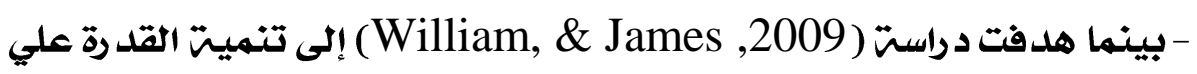

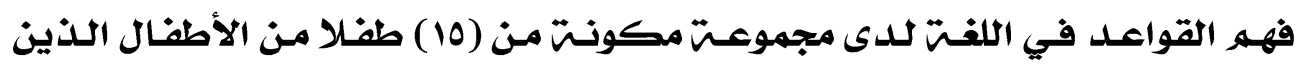

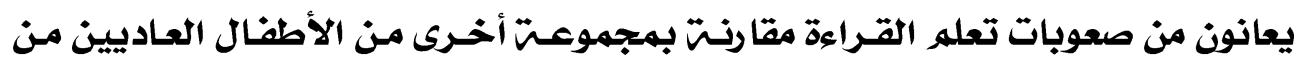

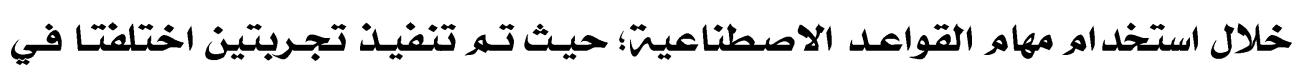

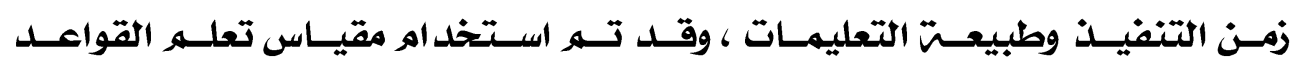

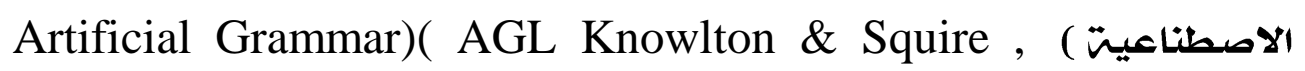

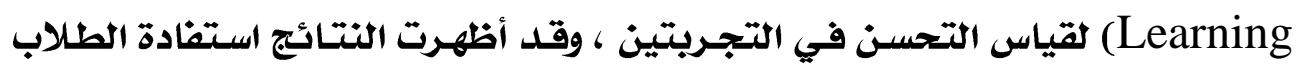

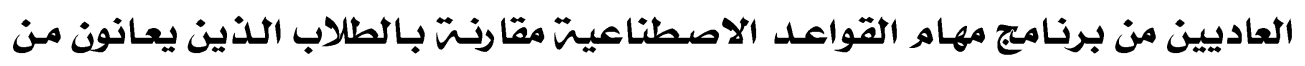

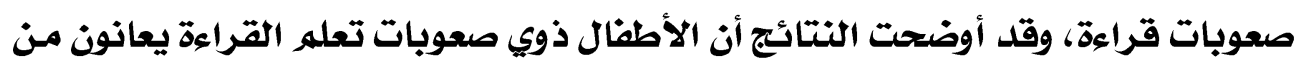

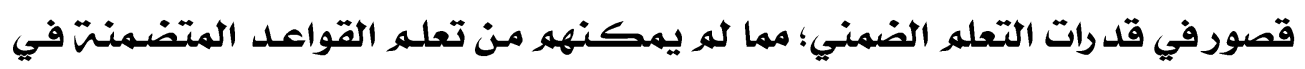

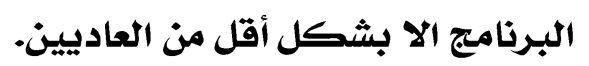

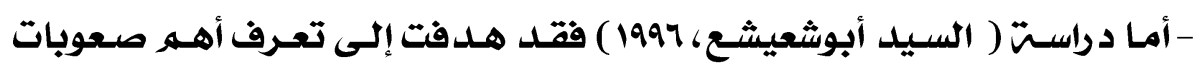

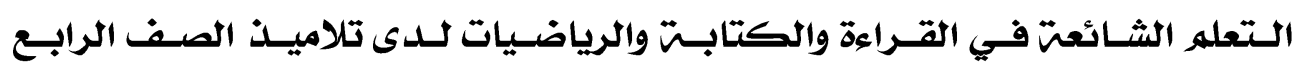

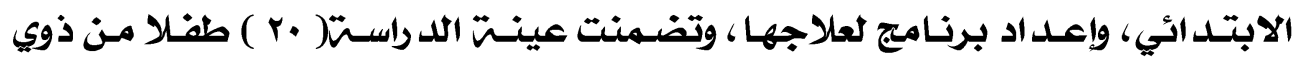

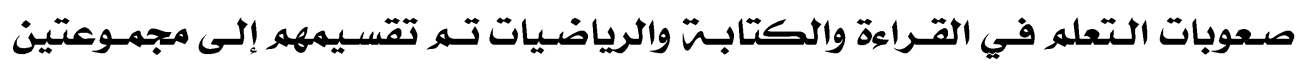

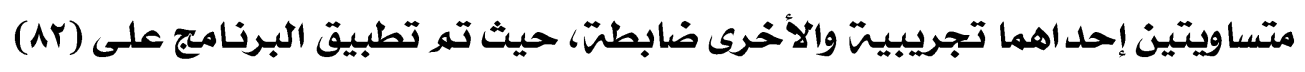

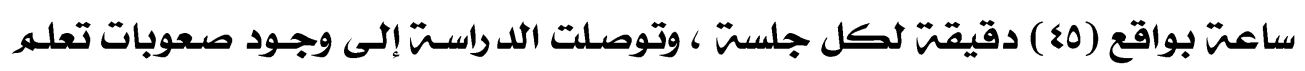

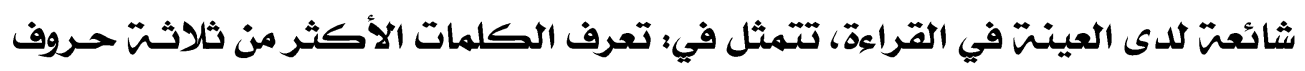

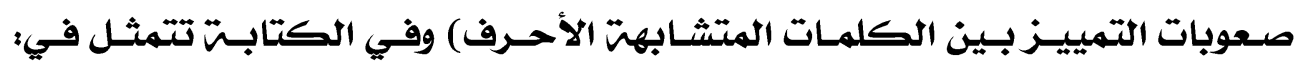




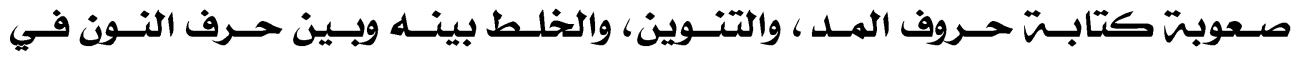

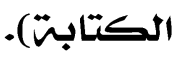

المحور الثانى :دراسات وبحوث تناولت فعاليت استخد اهو الفيديو التفاعلى مـع ذوى صعوبات تعلم القراءة والكتابت

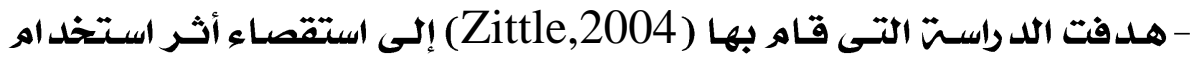

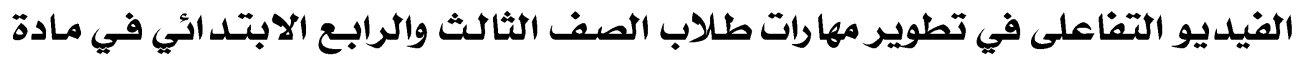

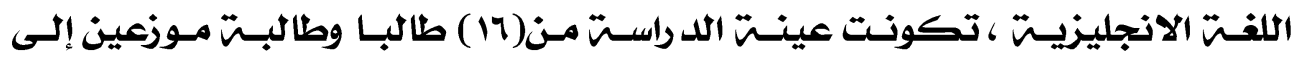

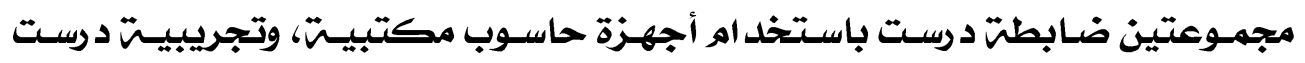

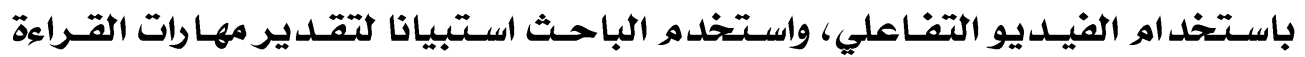

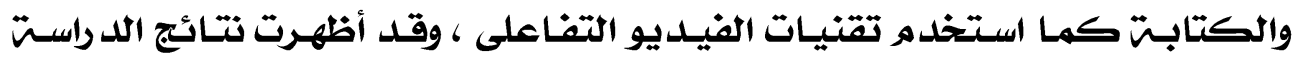

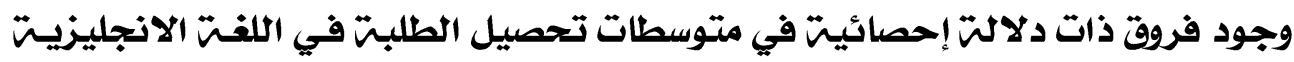

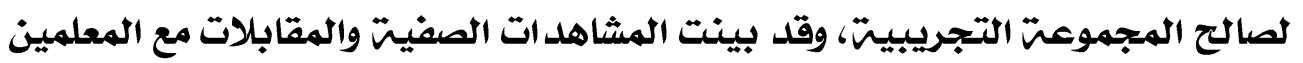

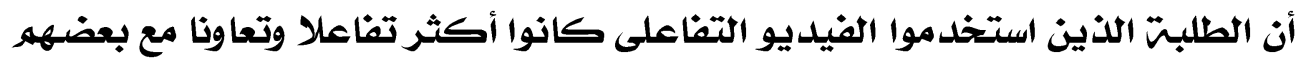
مقارنت بالطلبت الذين تعلموا باستخد اهر الحاسوب المكتئ المتبي.

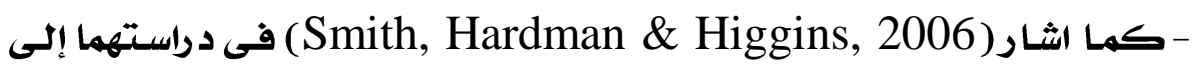

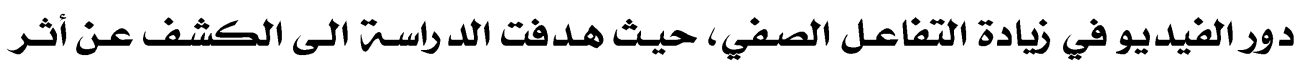

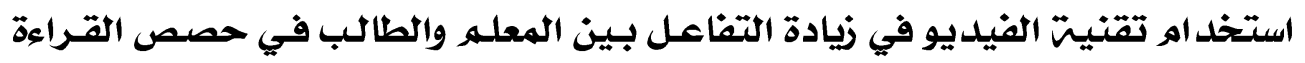

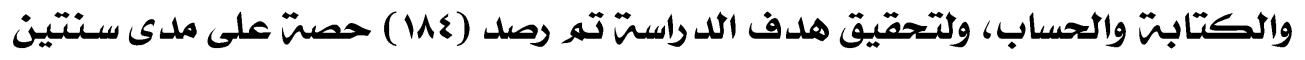

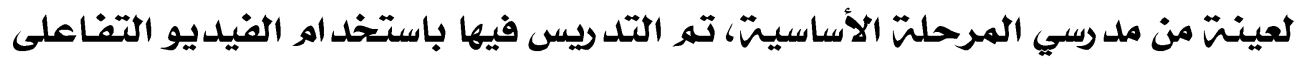

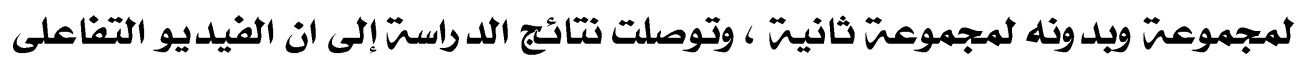

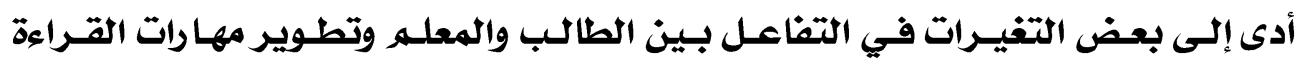

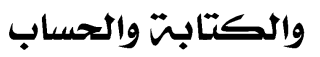

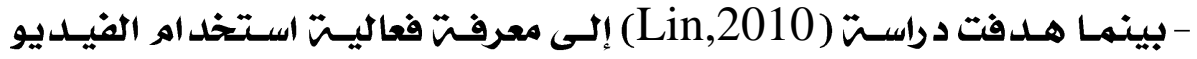

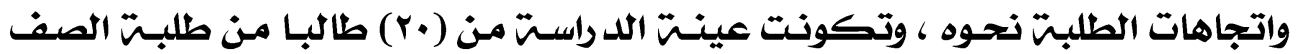

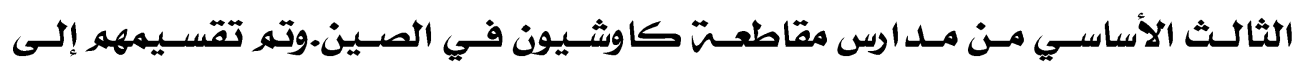

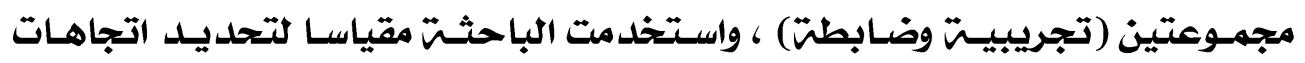

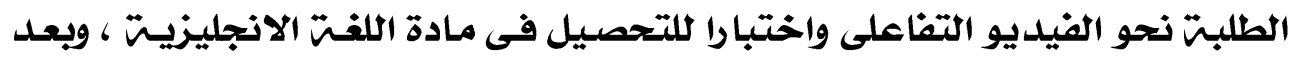

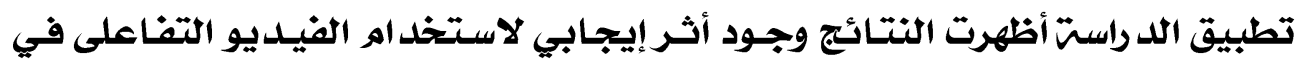

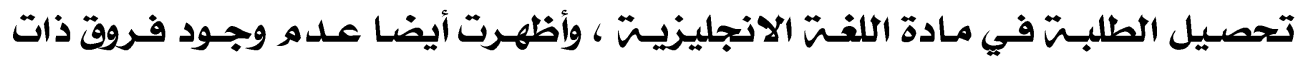

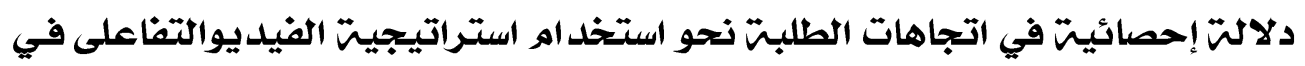
التد ريس.

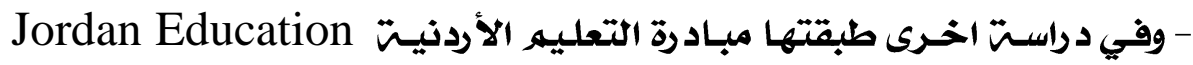

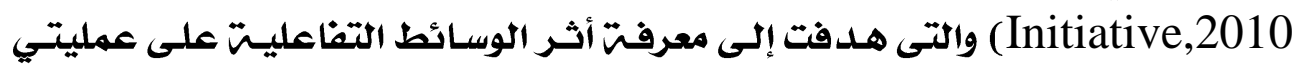


التعليهو والتعله في المد ارس الاستكشـافيت في عمان. شـملت الد راسـت (IVO ) طالبـاً

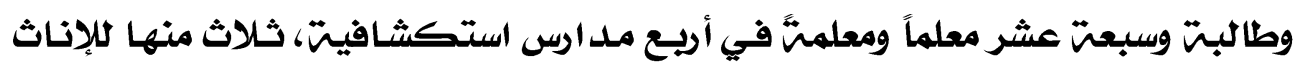

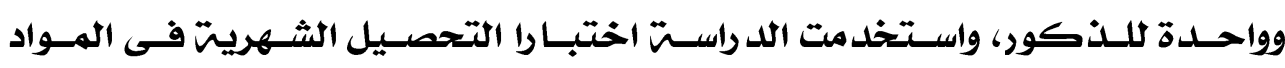

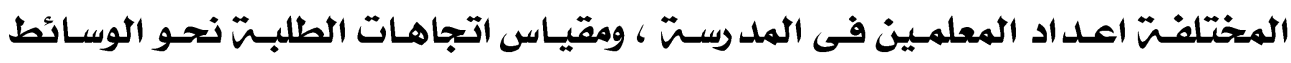

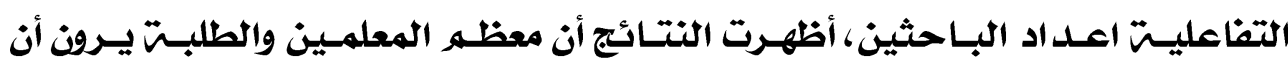

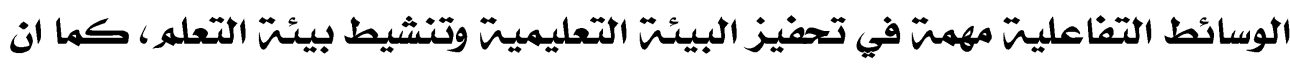

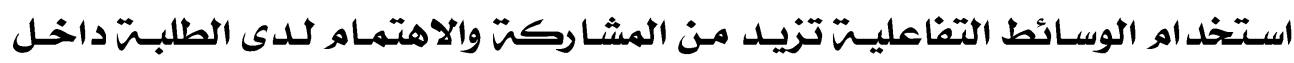
الفصول الد راسيته.

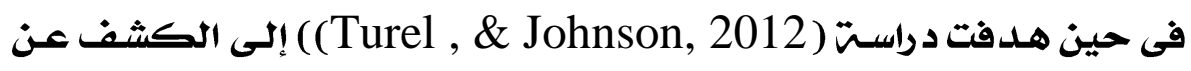

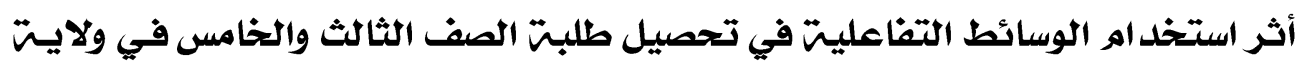

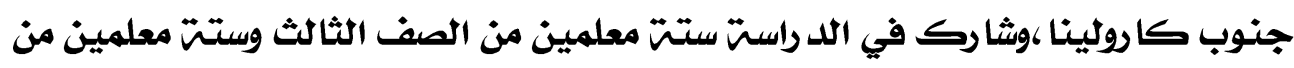

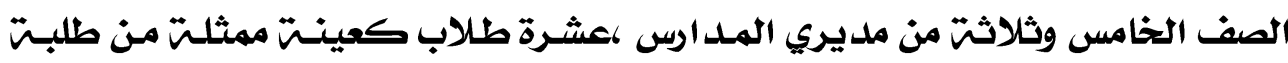

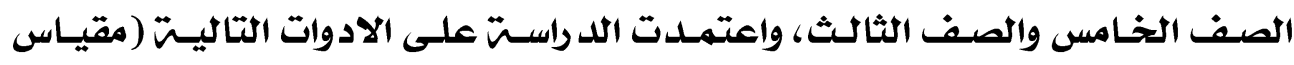

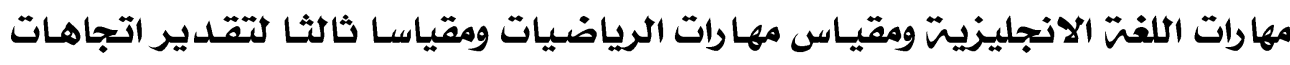

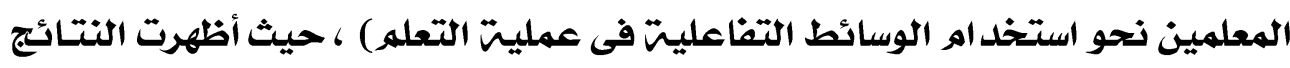

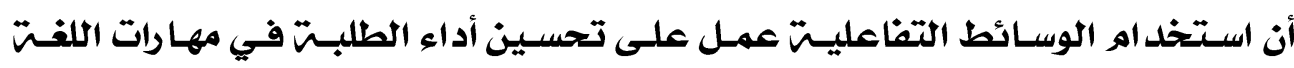

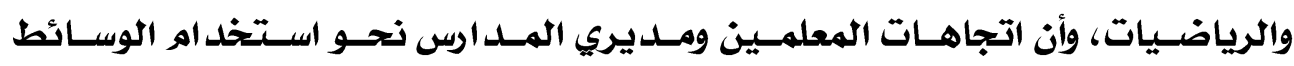

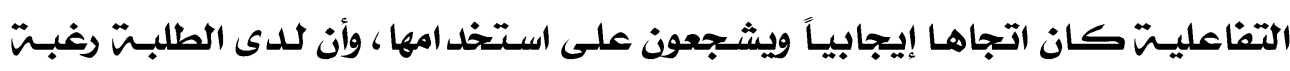

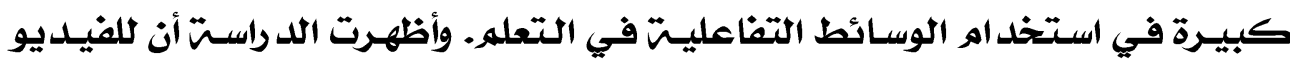

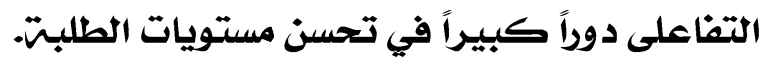

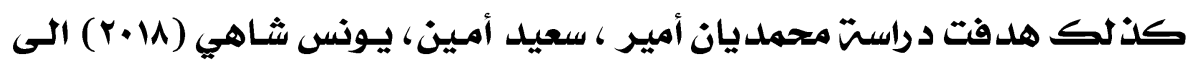

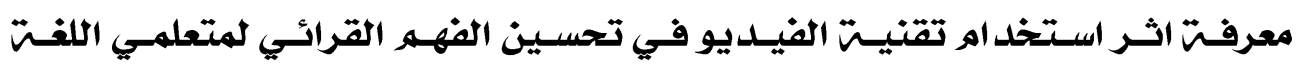

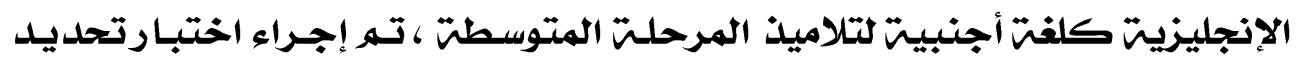

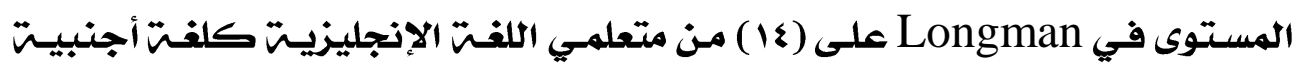

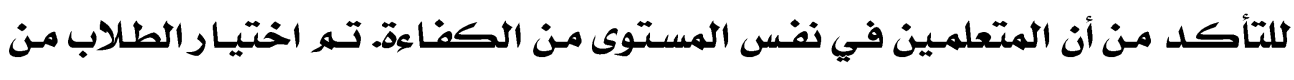

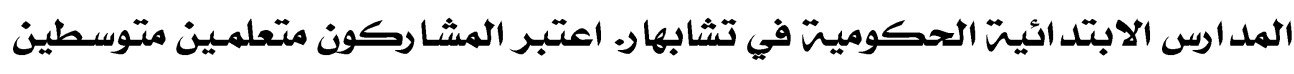

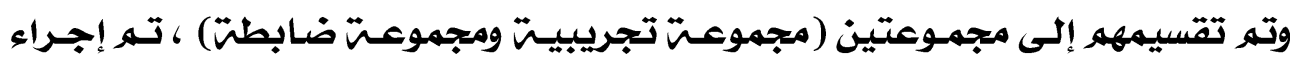

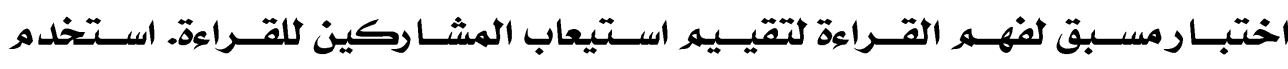

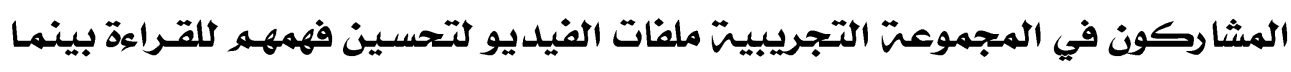

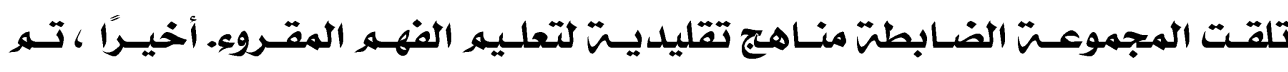

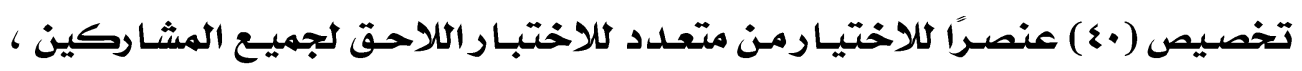

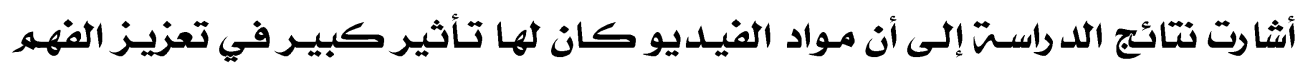

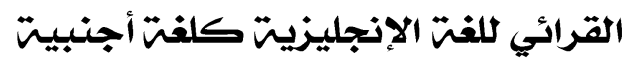




\section{التعقيب على الد راسات السابقن}

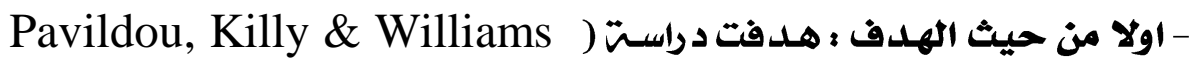

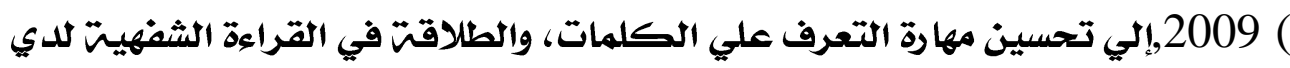

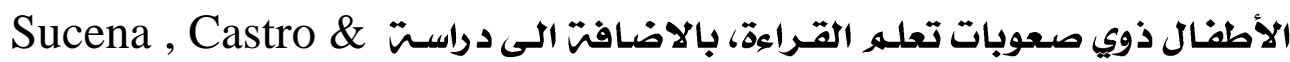

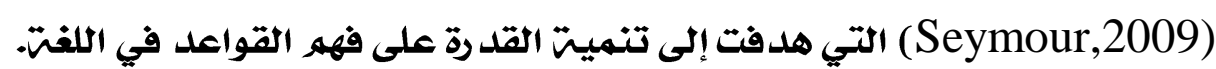

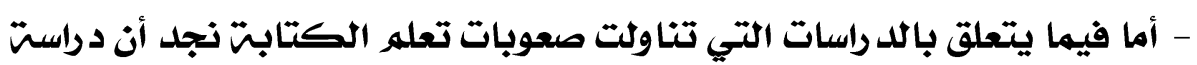

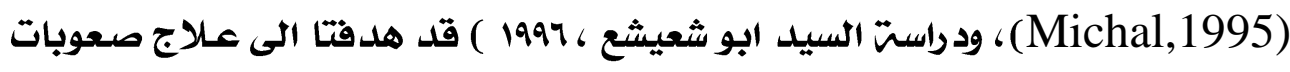

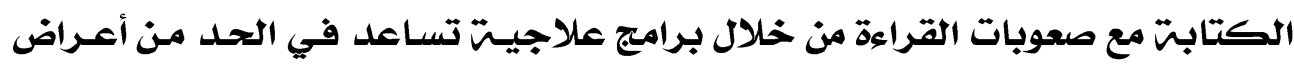

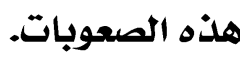

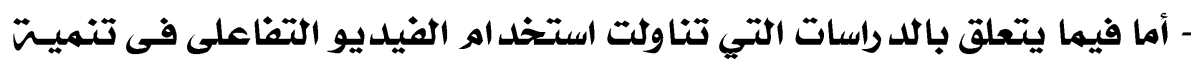

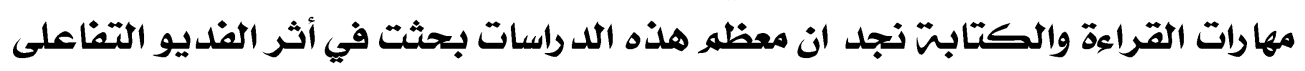

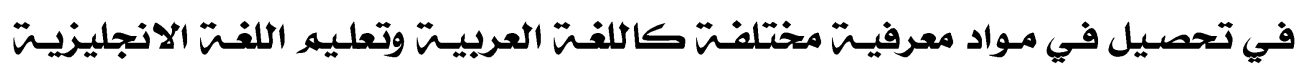

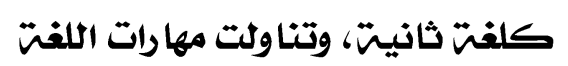

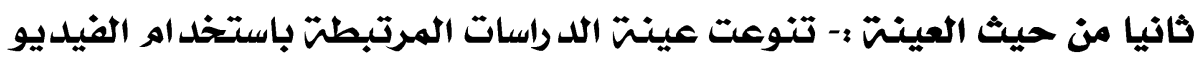

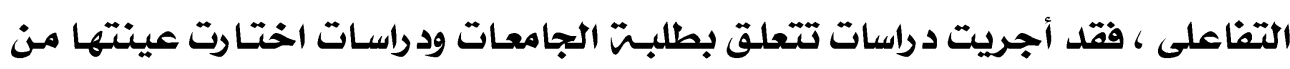

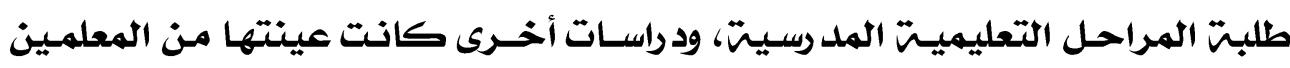
ومديري المدارس كلد راست ( Jordan Education Initiative,2010)

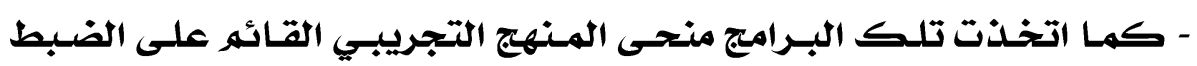

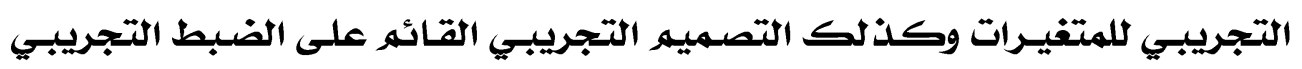

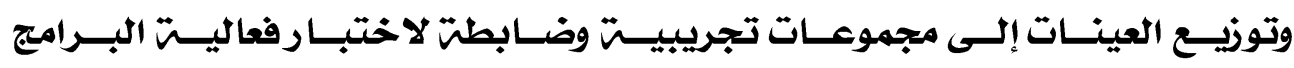

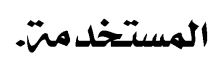

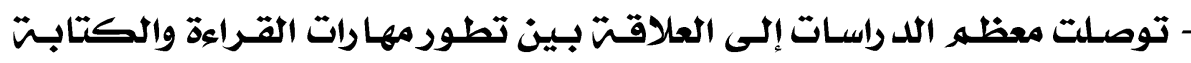

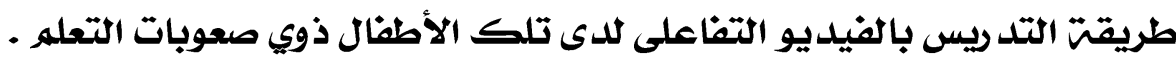

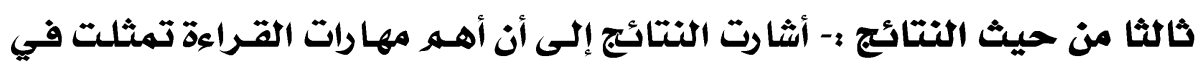

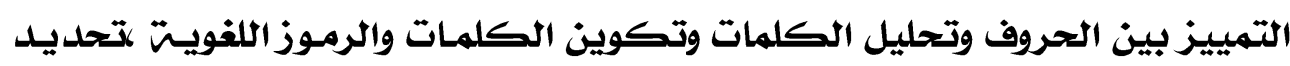

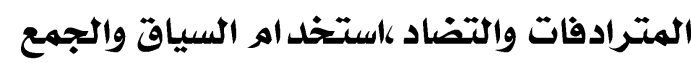

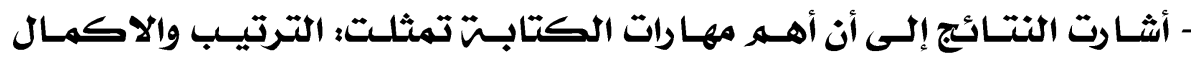

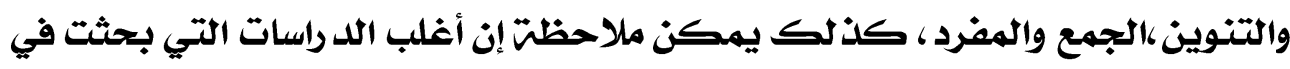

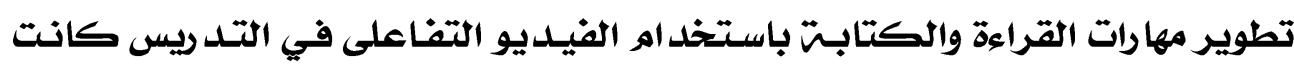

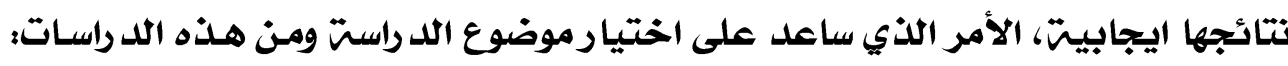

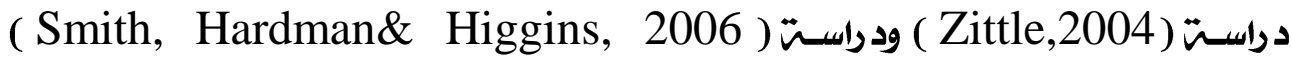

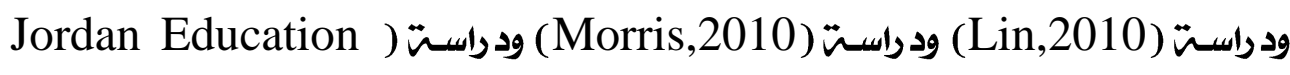

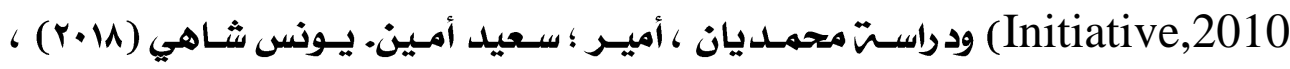




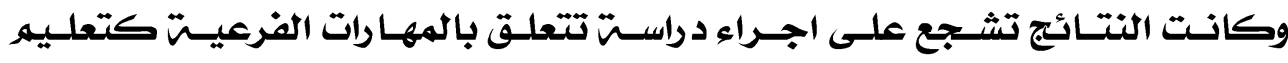

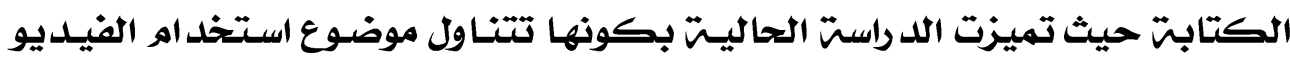

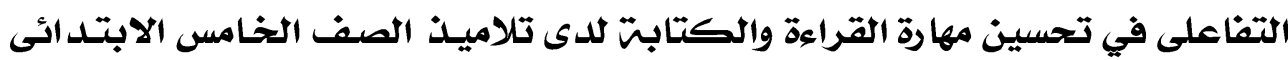

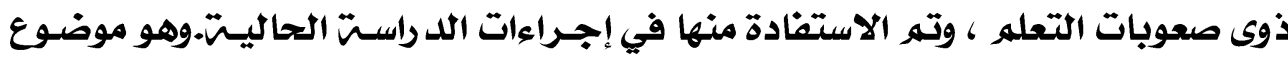
له يته دراسته حتى لحظت إعد اد هذه الد راست وحسب عله الباحثت.

فروض البحث:

في ضوء ما سبق من إطار نظري ودراسات سابقت يمكن صبياغت الفروض كما يلي:

ا - - توجد فروق دالت احصائيت بين متوسطات رتب درجات أفراد المجمـوعتين

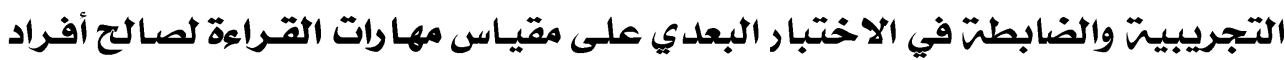
المجموعت التجريبيتة.

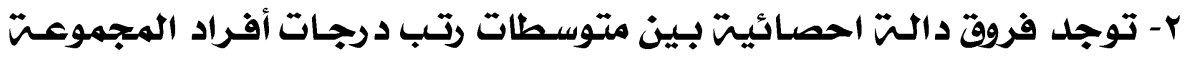

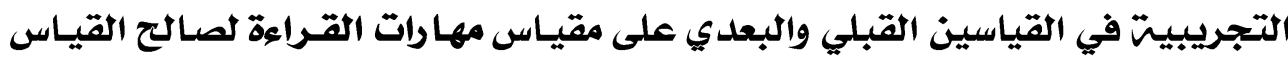

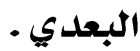

r- توجد فروق دالت احصائيت بين متوسطات رتب درجـات أفراد المجمـوعتين

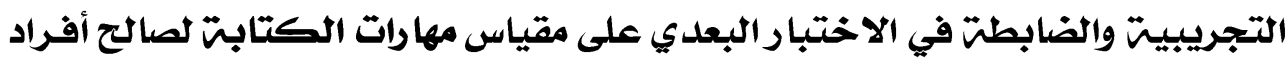
المجموعت التجريبيتة.

ع - - توجد فروق دالت احصائيت بين متوسطات رتب درجـات أفراد المجموعـت

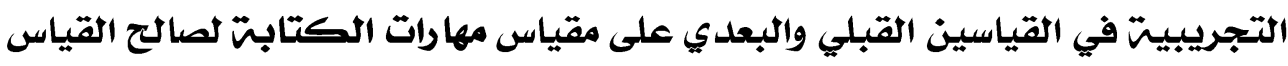

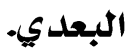

ـ - لا توجد فروق دالت احصائيت بين متوسطات رتب درجات أفراد المجموعت

التجريبيت في القياسين البعدي والتتبعي على مقياس مهارات القراءة

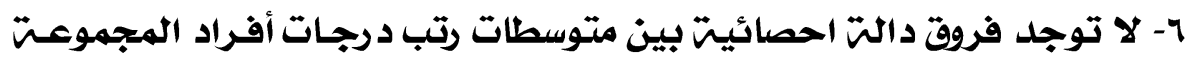

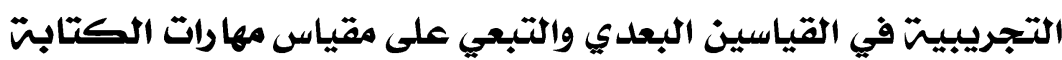

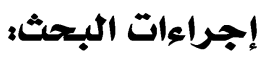

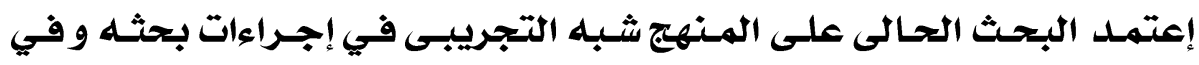

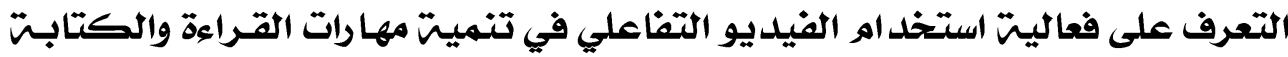

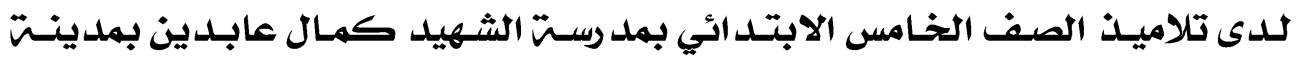
المرج بممحافظت القاهرة . اولا :عينت البحث

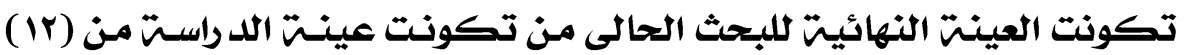
تلميذا من تلاميذ الصف الخامس الابتد ائي مما يعانون مـن ضعف في مهارات القـراءة 


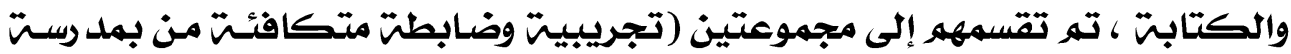

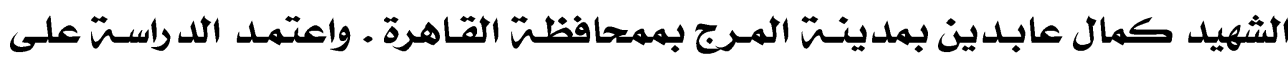

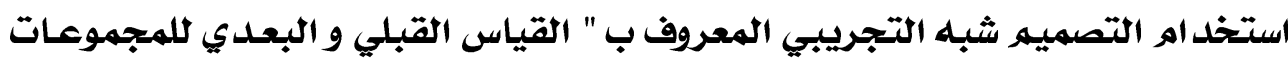

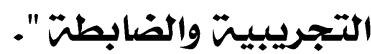
ثانياء أدوات البحث البحث

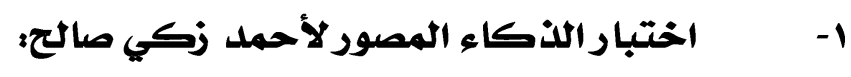

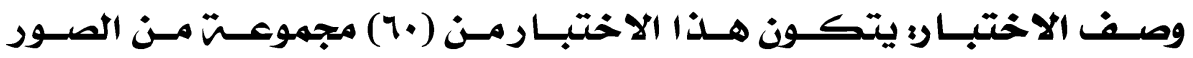

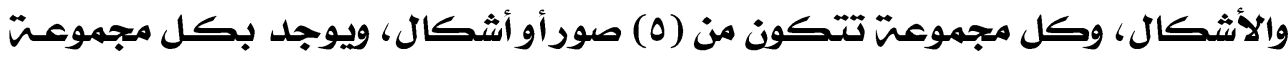

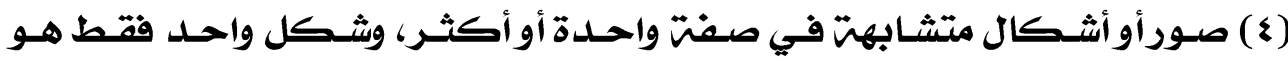
المختلف عن باقي أشكال المجموعترة

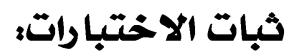

لقد حسبت معاملات ثبات هذا الاختبار في كثي كثير من الأبحاث التي استعمل

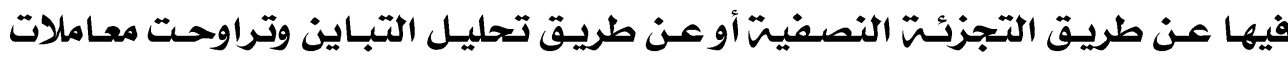

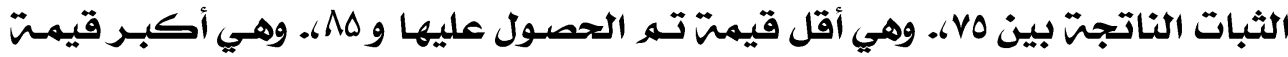

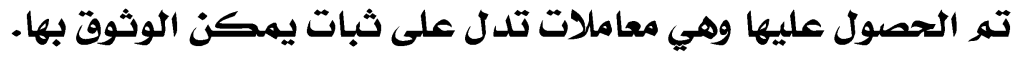

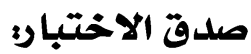

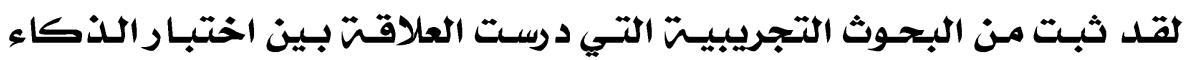

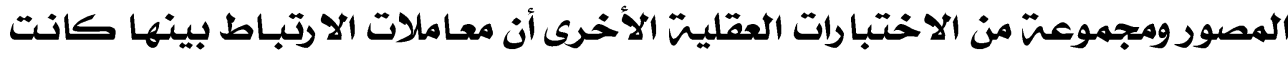

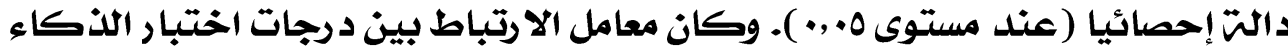

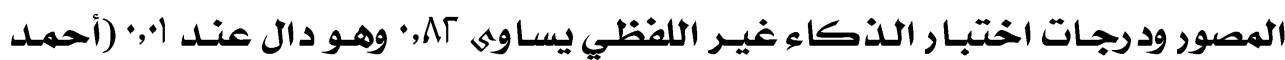

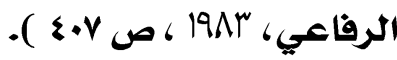

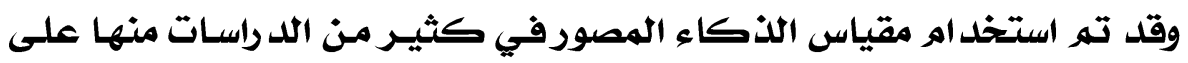

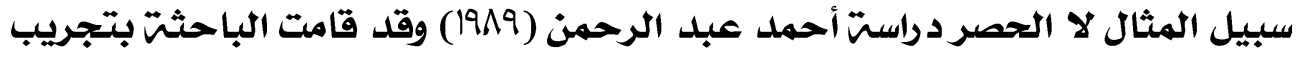

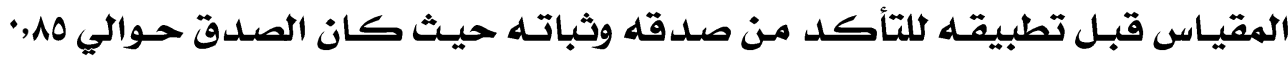

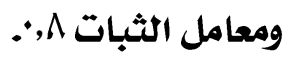

Г- مقياس صعوبات التعلم. إعداد السرطاوي، 1990.

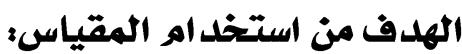
التعرف على طلاب الذين لديهي صعوبات الديات التعله للمراحل المبكرة. وصف المقياس،

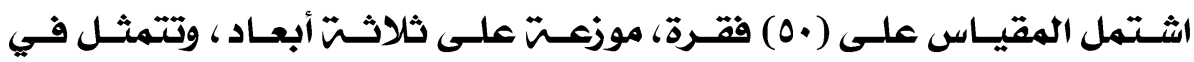

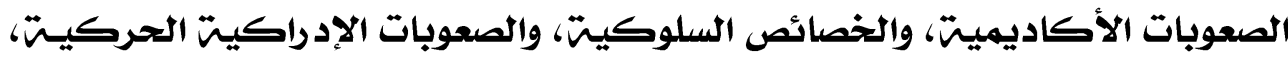

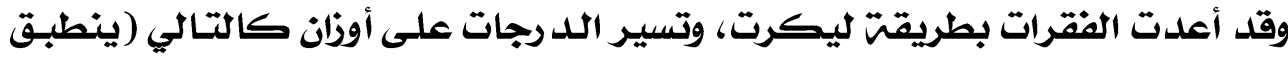

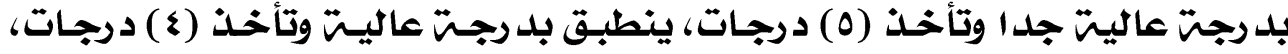




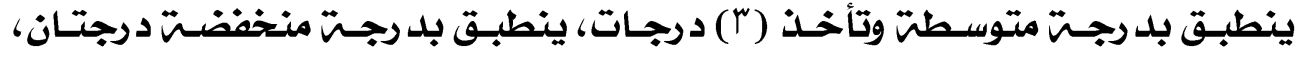

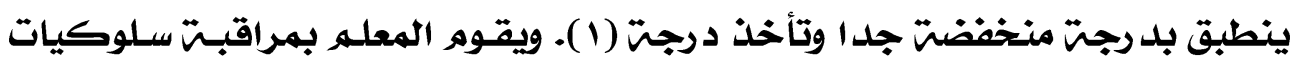

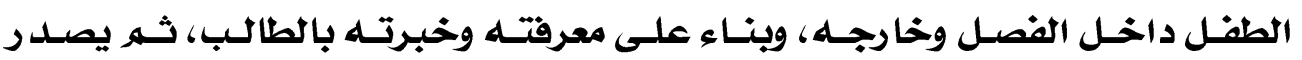

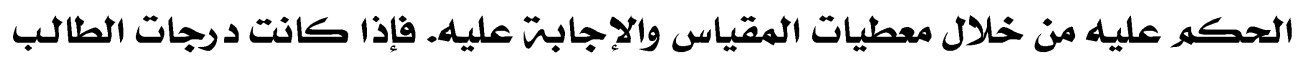

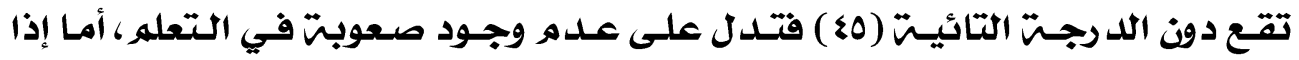

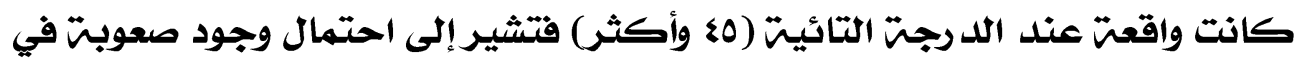

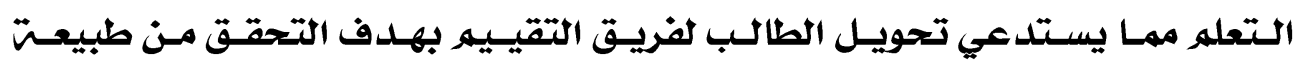

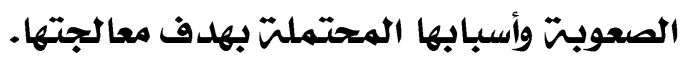

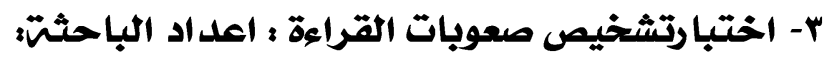

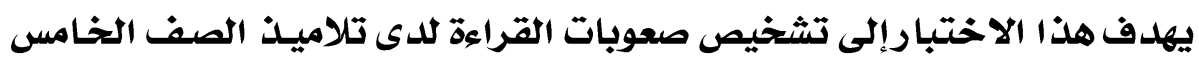

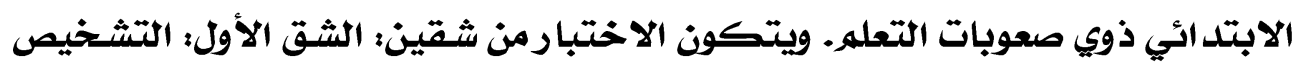

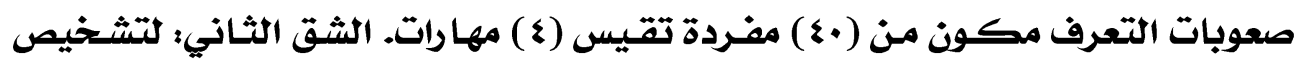

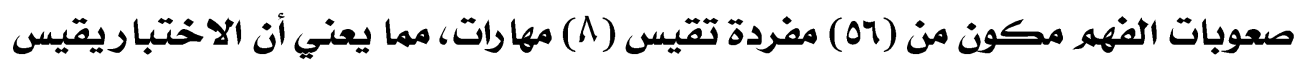

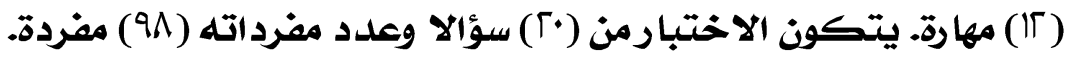
صدق الاختبارة

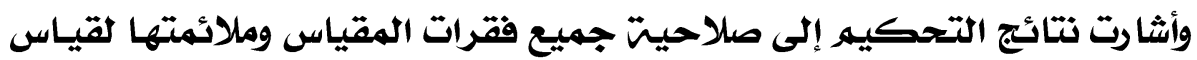

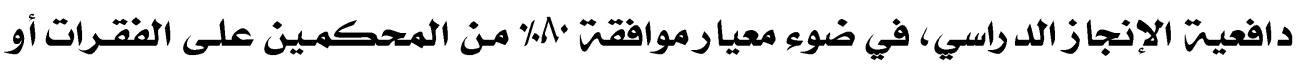

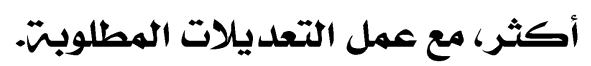
ثبات الاختبار، ته حساب ثبات الاختبار باستخد اهر طريقت التجزئت النصفيت

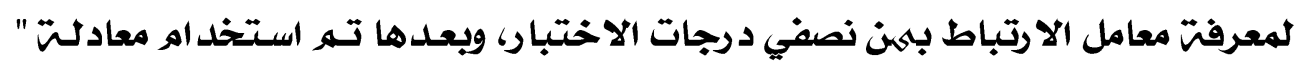

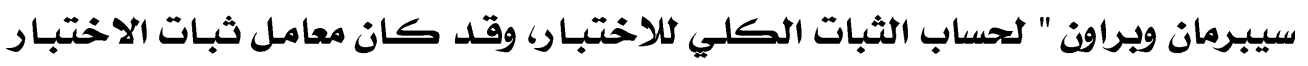

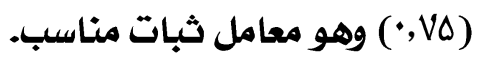

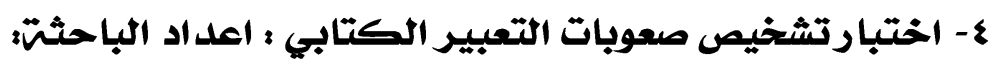

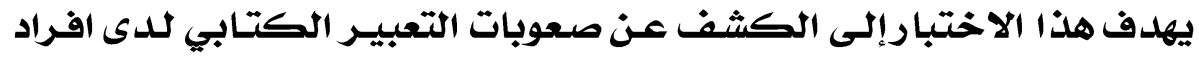

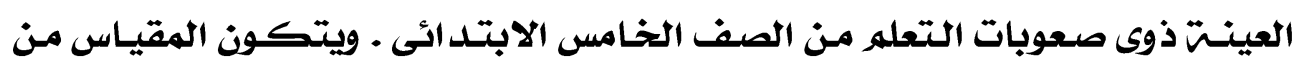

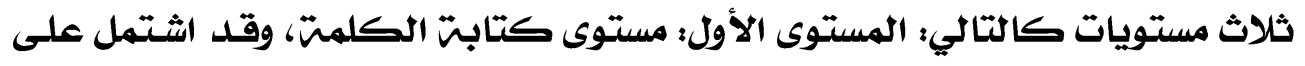

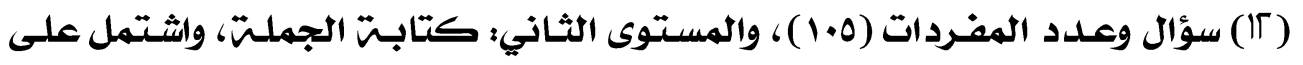

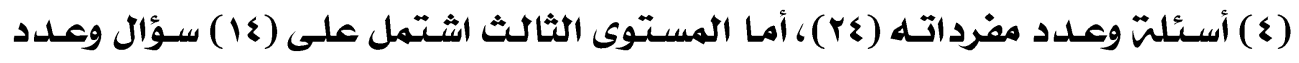

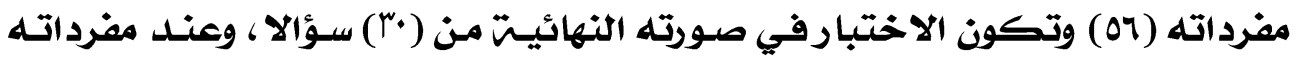
(1M9)

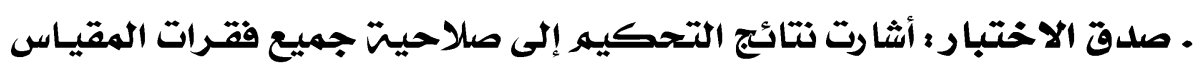

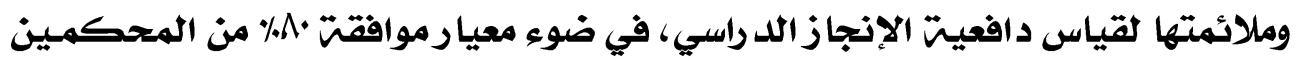

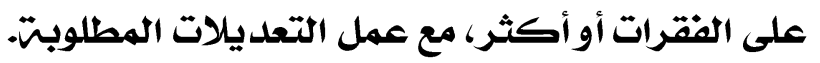




\section{ثبات الاختبارو}

ته حساب ثبات الاختبار باستخد اهو طريقت التجزئت النصفيت المعرفت معامل

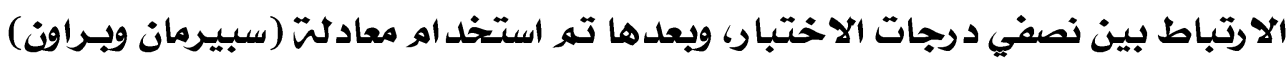

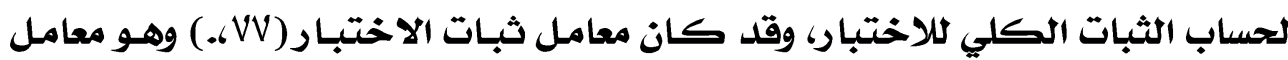
ثبات مناسب.

ه- البرنامج التد ريبي القائم على استخدام الفيديو التفاعلى لتتميت مهارات القراءة والكتابت للى التلاميذ ذوي صعوبات التعلم. إعلداد الباحثتئ.

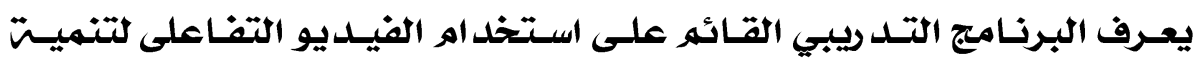

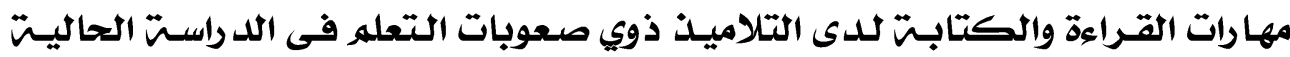

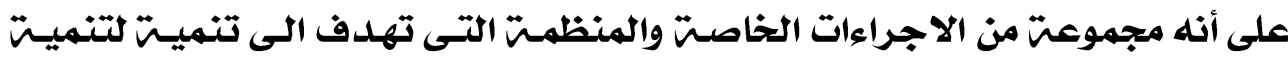

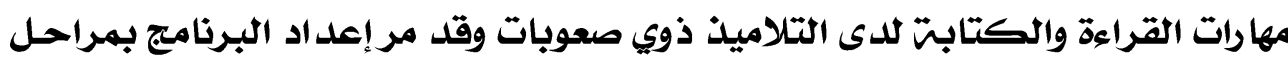
تفصيلها ما يلي:

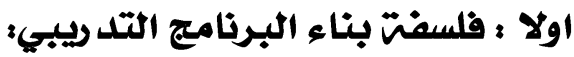

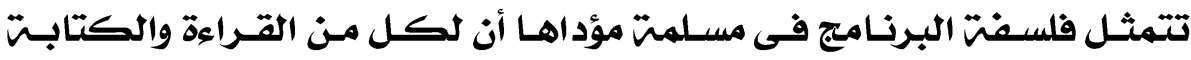

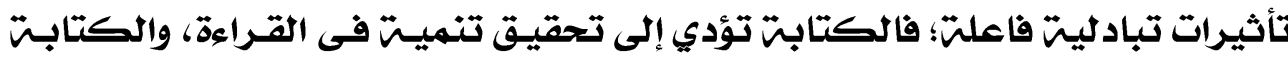

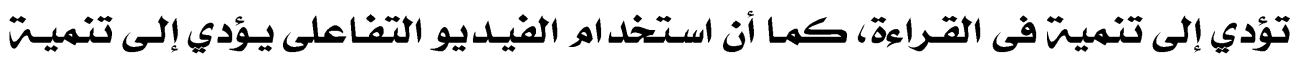

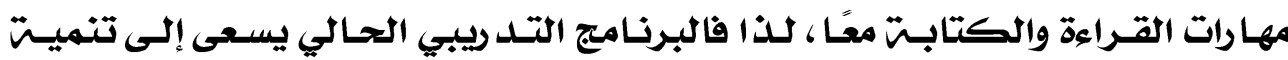
مهارات القراءة والكتابت لدى تلاميذ الصف الخامس الابتد ائى ذوي صعوبات التعله باستخد اهر الفيديو التفاعلى .

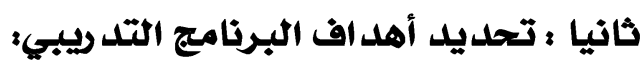

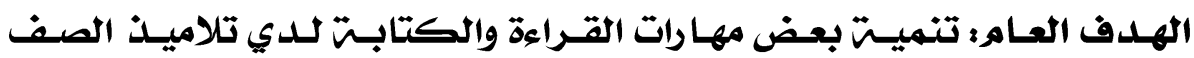

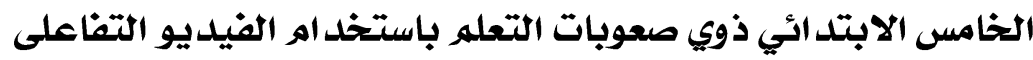

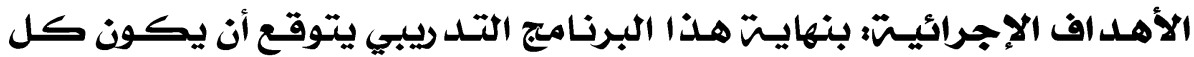
تلميذ/ تلميذة قادرًا على أن: - يكتب كلمات من حروف معطاة.

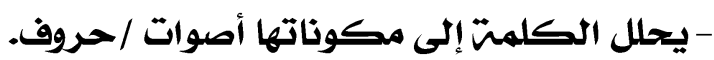
- يحدد مفهوهر كل فقرة موضع التد ريب. - يكتب ما يملى عليه من كلمات بسرعت مناسبت.

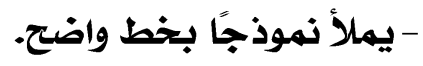

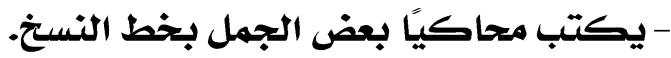
- ينطق الكلمات دون حذف أو إضافت أو إبلد الدمال. - يميز بين الحروف المتشابهت في رسمها.

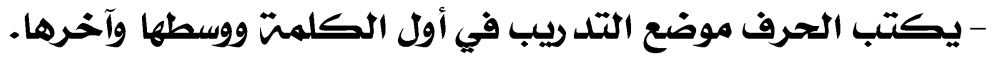


- يكتب مراعيًا المسافات المناسبت بين الحروف والكلمات والجمل.

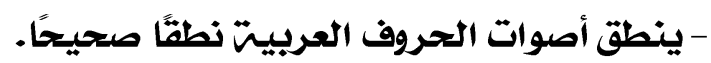

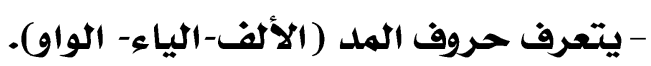
- يتعرف رسهر الحرف مع الحرفات الثماثلاث من خلال كلمات المات.

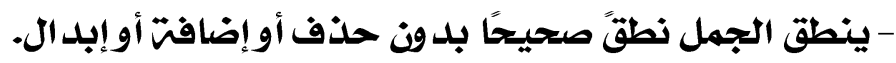
- يقسهر الكلمت إلى أصواتها.

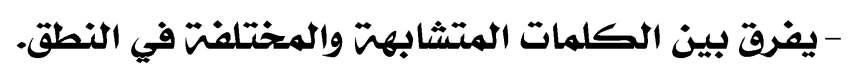
- ينطق الحرف موضع التد ريب نطقًا صحيحًا.

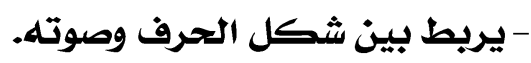

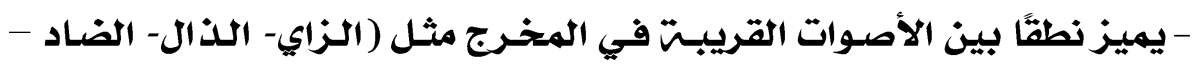
الد ال - الثاء - السين).

- يحلدد الكلمات المشتملت على الحرف موضع التد ريب في مواضع مختلفت من الكلمت.

$$
\text { - يتعرف الحرف موضع التد ريب في الكلمات المنطوف موضتم. }
$$

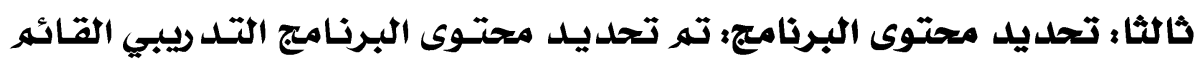

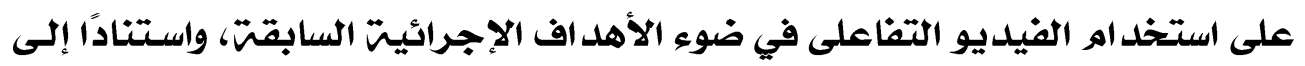

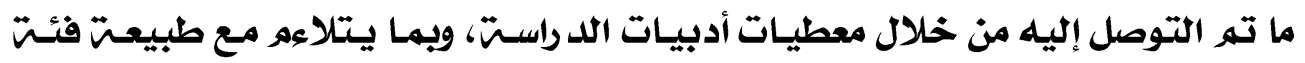

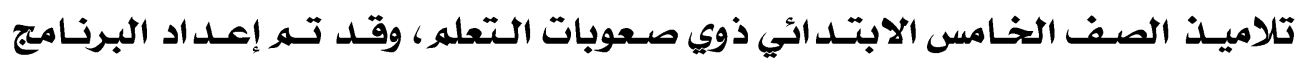

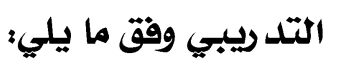

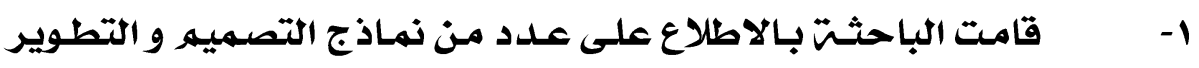

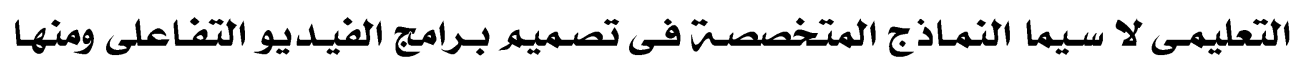

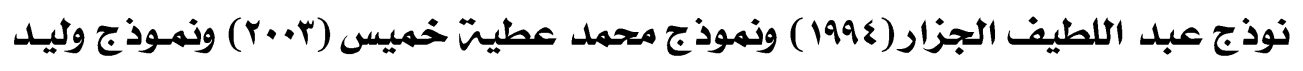

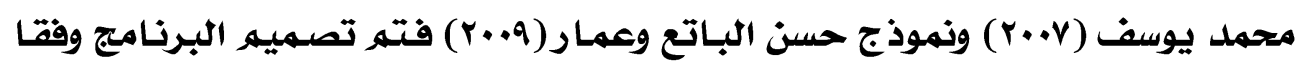
للخطوات التاليت

الخطـوة الأولىى: تصـميهر نظاهر الفيـليو التفـاعلي: وتتضـمن هـذه المرحلـت

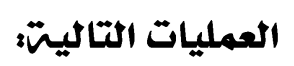

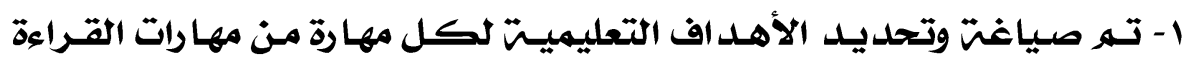

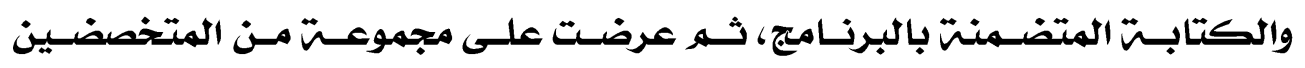

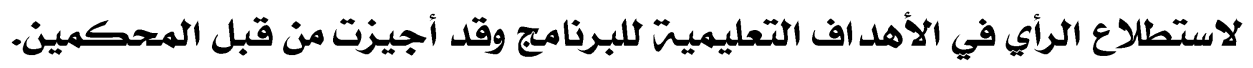

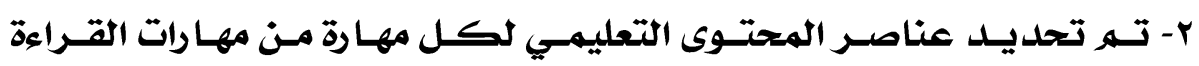

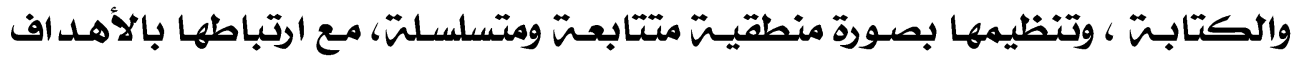

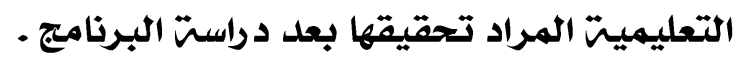


با تـه بنـاء مقياسـين لمهارات القـراءة ومهارات الكتابـت ثهـ اختيـار الفيـديو

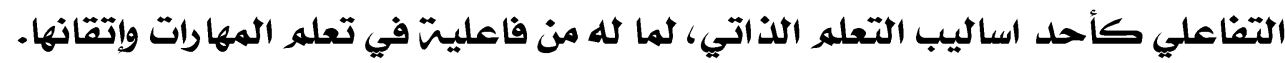

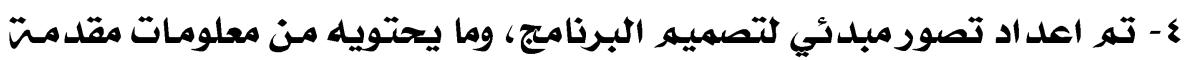

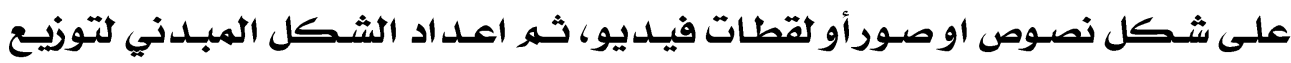

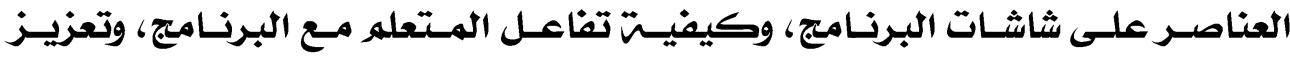

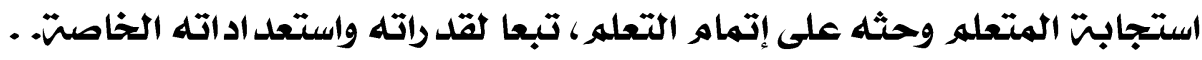

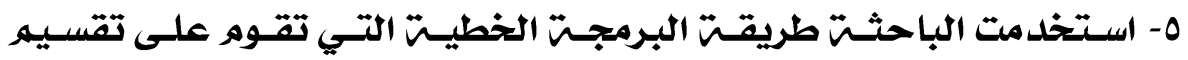

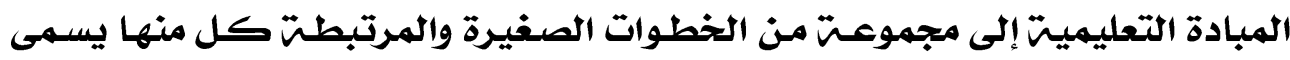

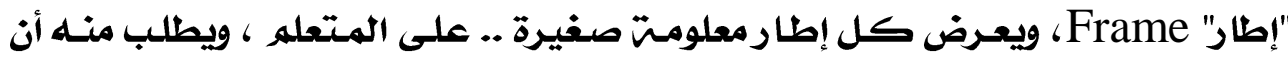

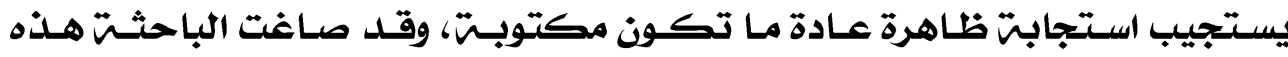

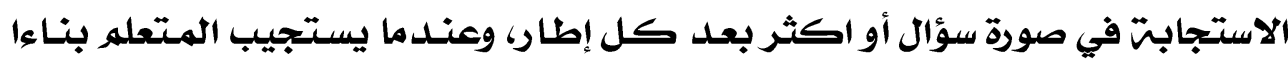

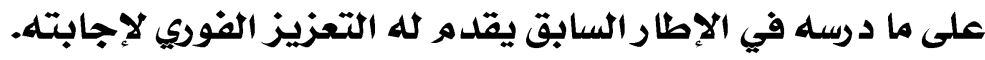

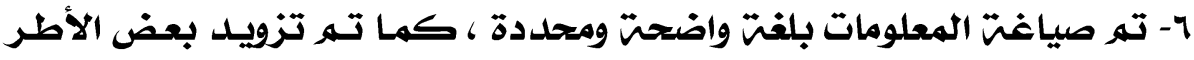

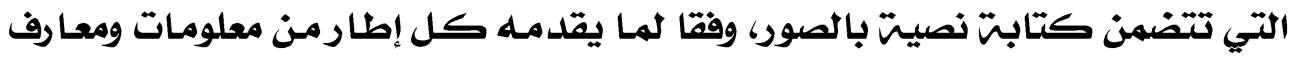

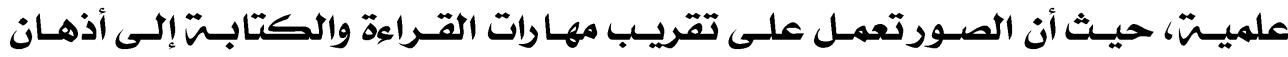

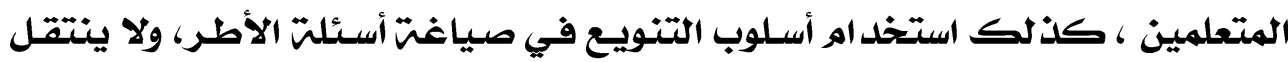

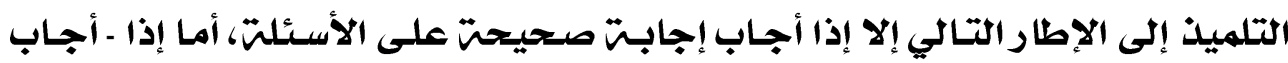

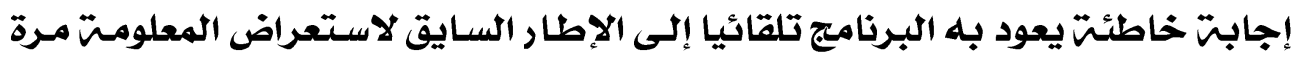

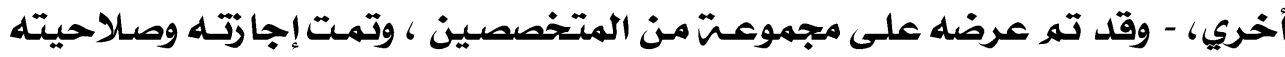
كلإنتا ج.

الخطوة الثانيتّ: إنتاج نظاهر الفيـليو التفـاعلي: وتشمل عمليـت إنتاج نظاهر

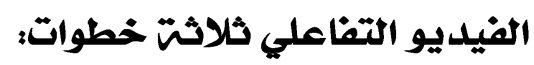

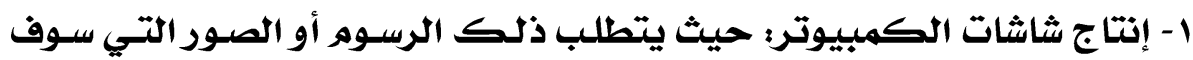

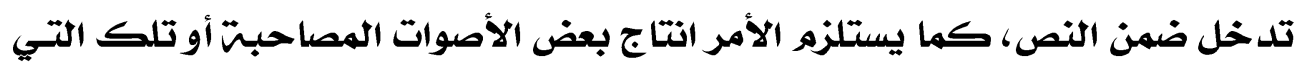

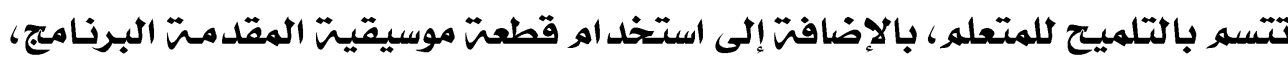

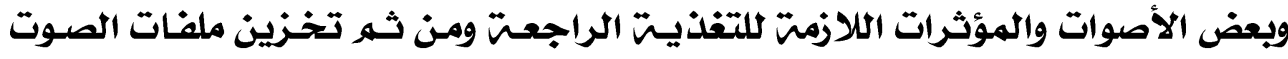

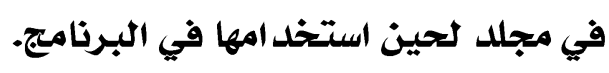

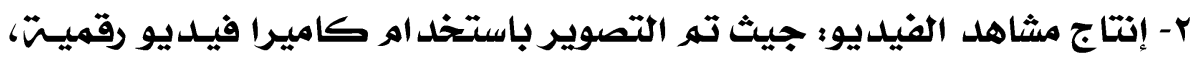

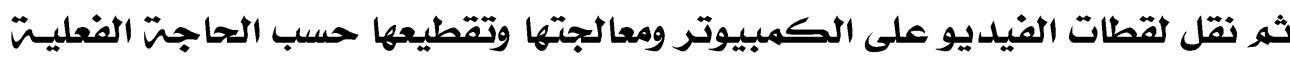
لها (عمل المونتاج).

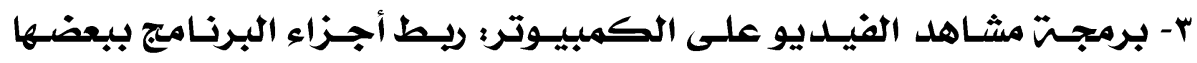

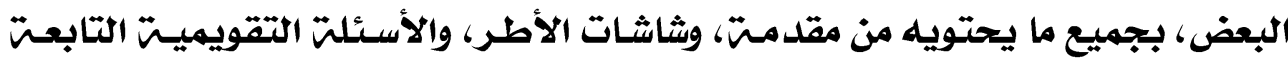


لها، وتعزيز الاستجابت، وخاتمت البرنامج، عن طريق تفعيل وتنشيط المفاتيع التي التي

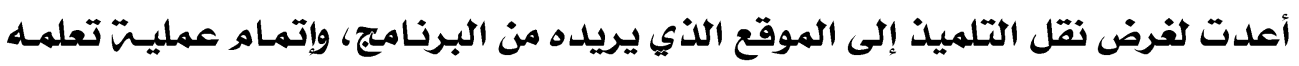

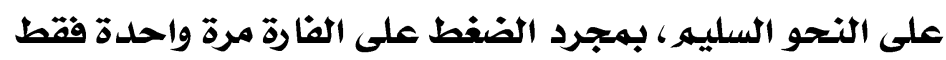

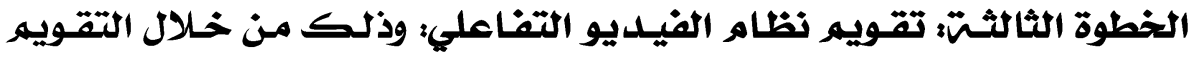

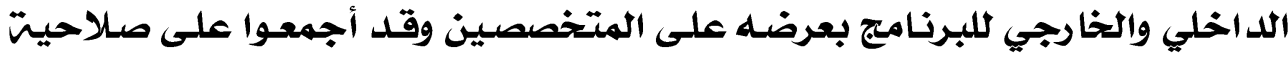

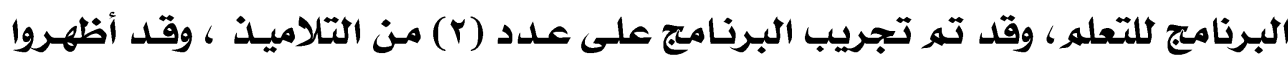

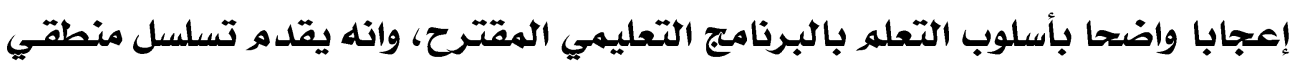

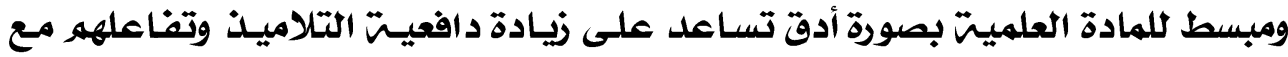
البرنامج

$$
\text { رابعا : ملدة البرنامج التلديبى البيرئ }
$$

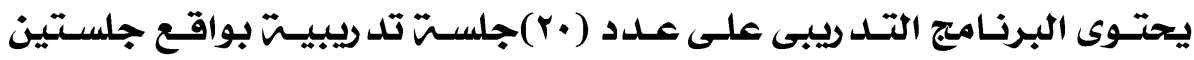

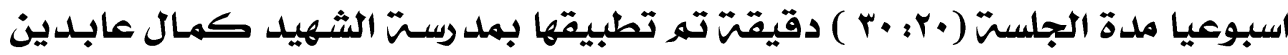
بأدارة المرج التعليميت بهحافظت القاهرة

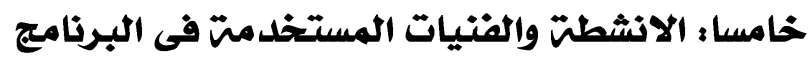

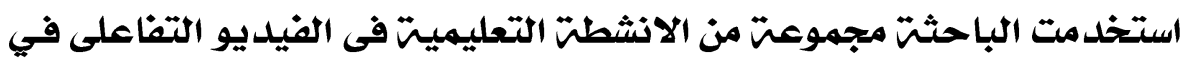

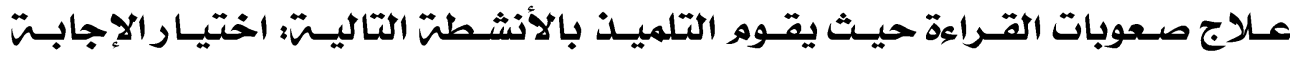

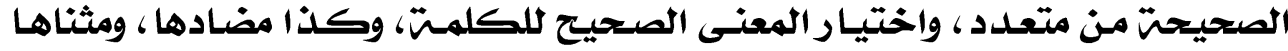

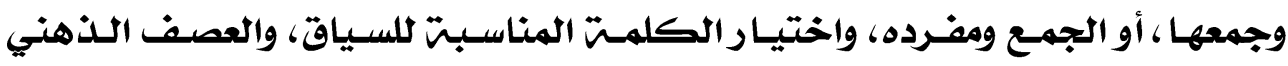

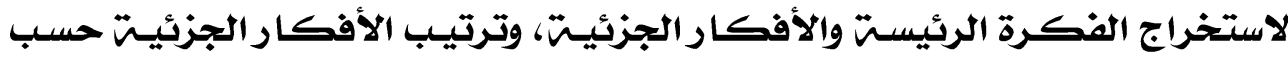

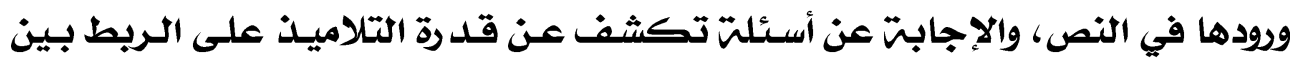
الأسباب والنتائج.

$$
\text { أما الأنثطت التعليميتّا في علاج صعوبات التعبير الكتابي: }
$$

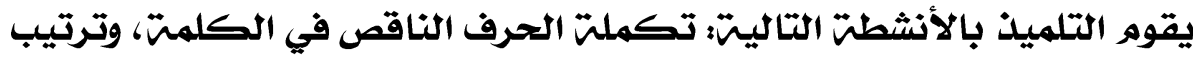

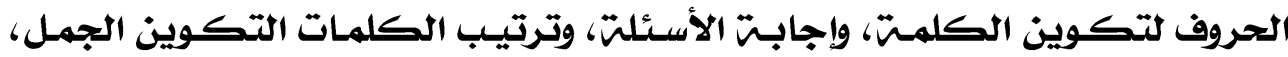

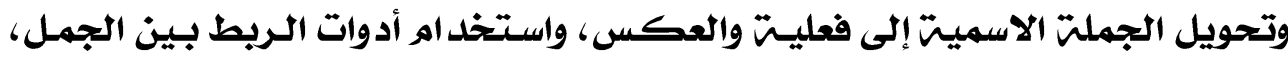
ووضع علامات الترقيه أثناء الكتابت بين الجمل والفقرات، وترتيب الجمل لتكـوين

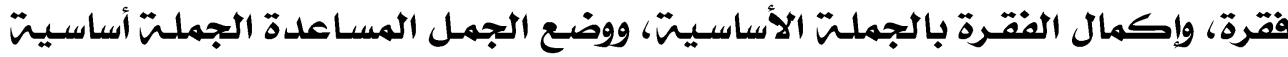

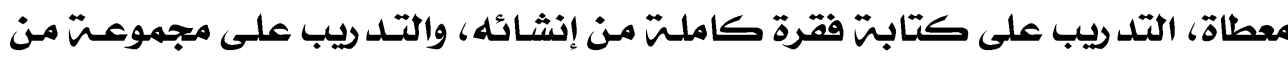
الأنشطت التي تنمي الفهه القرائي. سابعا :صلد المحتوى للبرنامج المرئي التعليمي 
تـو عرض البرنامج التعليمي بجميع مكوناتـه مـن مقاطع الفيـديو والسينا ريو

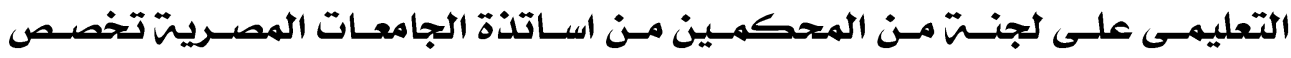

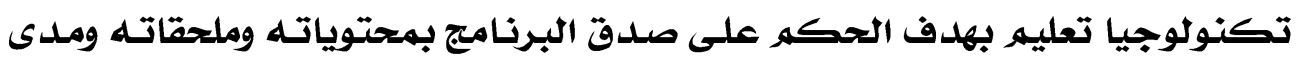

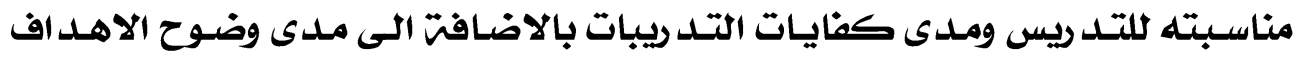

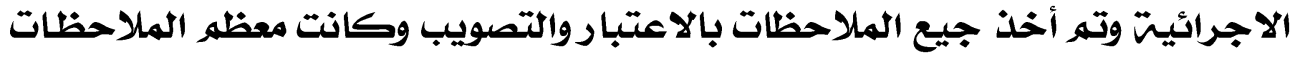

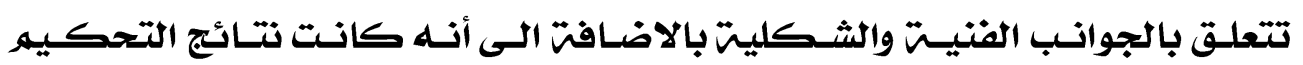

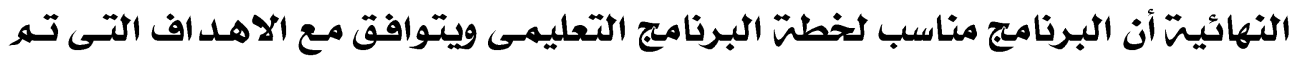

اعد ادها

عرض النتائج وتفسيرها:

تحقيقًا لأهد اف البحث فقلد جرت معالجت بيانات البحث إحصائيا وفيما يلى

عرضًا لما تم التوصل إليه من نتائج.

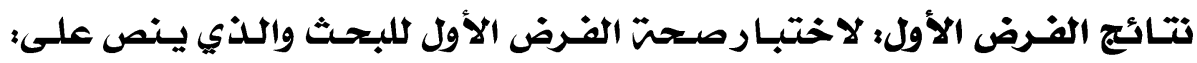

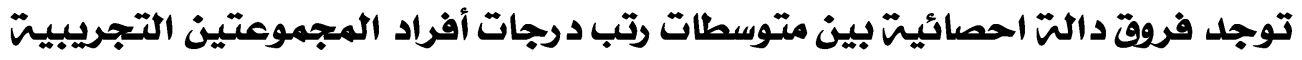

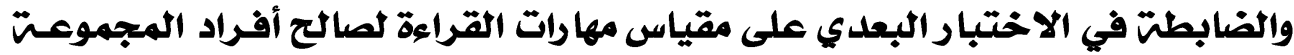

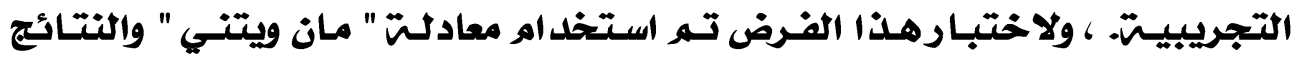
موضحت كما يلي

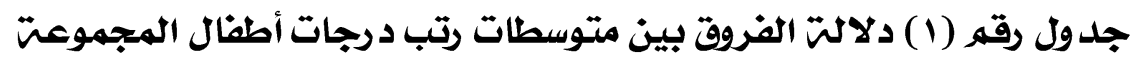
التجريبيتت ومتوسطات رتب درجات المجموعت الضابطت في القياس ألبعدي

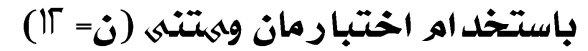

\begin{tabular}{|c|c|c|c|c|c|c|c|c|}
\hline الدجاه & مستوى & قيمت & مجموع الرتب & متوسط الرتب & دا & الهجموعن & قالابعاد / & هر \\
\hline \multirow[t]{2}{*}{ التجريبيت } & \multirow[t]{2}{*}{$\because 1$} & \multirow[t]{2}{*}{$\Gamma .99 \mathrm{~V}$} & $\Delta 0$ & $9.1 \mathrm{~V}$ & 9 & الضابطت & \multirow{2}{*}{ 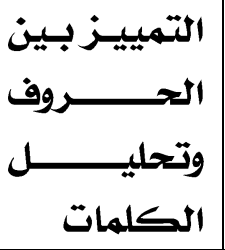 } & \multirow[t]{2}{*}{1} \\
\hline & & & $\mu \nu$ & ${ }^{\mu}{ }^{\prime} \Lambda \mu$ & 7 & التجريبيت & & \\
\hline \multirow[t]{2}{*}{ التجريبيتت } & \multirow[t]{2}{*}{0.01} & \multirow[t]{2}{*}{ r.quq } & 07.0 & 9.45 & 7 & الضابطت & \multirow{2}{*}{ 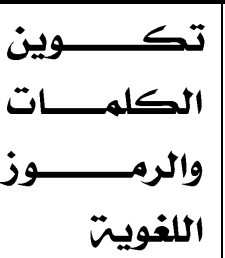 } & \multirow[t]{2}{*}{$\Gamma$} \\
\hline & & & $\Gamma 1.0$ & $r . \Delta \Lambda$ & 7 & التجريبيتة & & \\
\hline \multirow[t]{2}{*}{ التجريبيتت } & \multirow[t]{2}{*}{0.01} & \multirow[t]{2}{*}{ r.vHT } & 07 & $q_{6} r r$ & 7 & الضابطت & \multirow{2}{*}{ 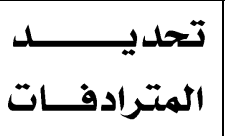 } & $r$ \\
\hline & & & $\Gamma \Gamma$ & r.ve & 7 & التجريبيت & & \\
\hline
\end{tabular}




\begin{tabular}{|c|c|c|c|c|c|c|c|c|}
\hline الدجاه & مستوى & قيمت & الرجب & متوسط & 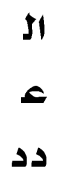 & الهجموعت & قالابعاد / & هر \\
\hline & & & & & & & والتضاد & \\
\hline \multirow[t]{2}{*}{ التجريبيتت } & \multirow[t]{2}{*}{0.01} & \multirow[t]{2}{*}{ r.in } & or & $9.0^{\circ}$ & 7 & الضابطت & \multirow{2}{*}{ 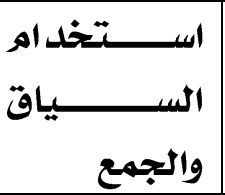 } & \multirow[t]{2}{*}{ p } \\
\hline & & & $\Gamma$ & $r . \Delta \Delta^{\circ}$ & 7 & التجريبيتت & & \\
\hline \multirow[t]{2}{*}{ التجريبيتت } & \multirow[t]{2}{*}{0.01} & \multirow[t]{2}{*}{$\Gamma .91$} & 57 & 9.50 & 7 & الضابطت & \multirow{2}{*}{ الافيكــــــــاصـار } & \multirow[t]{2}{*}{$\Delta$} \\
\hline & & & 21 & 3.50 & 7 & التجريبيتن & & \\
\hline \multirow[t]{2}{*}{ التجريبيتت } & \multirow[t]{2}{*}{0.01} & \multirow[t]{2}{*}{$\Gamma .90$} & 57 & 9.50 & 7 & الضابطن & \multirow{2}{*}{ 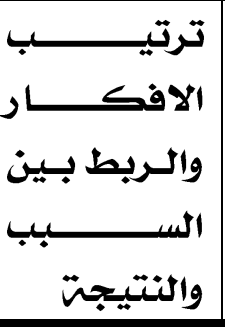 } & 9 \\
\hline & & & 21 & 3.50 & 7 & التجريبيتت & & \\
\hline \multirow[t]{2}{*}{ التجريبيتة } & \multirow[t]{2}{*}{0.01} & \multirow[t]{2}{*}{ Г.ANV } & 57 & 9.5 & 7 & الضابطت & \multirow{2}{*}{\multicolumn{2}{|c|}{ 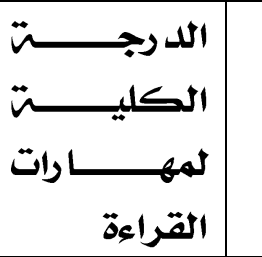 }} \\
\hline & & & 21 & 3.5 & 7 & التجريبيتت & & \\
\hline
\end{tabular}

يتضح من الجدول السابق أن هنـاك فروقا دالتت إحصائيا بين متوسطات رتب

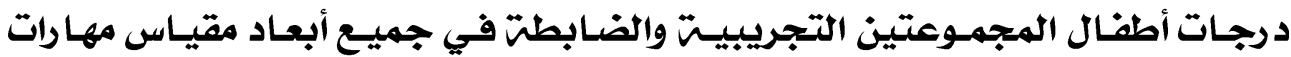

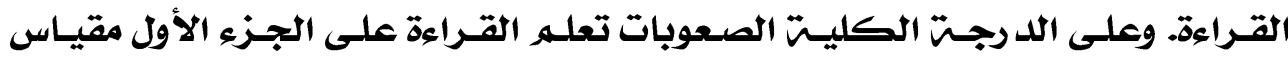

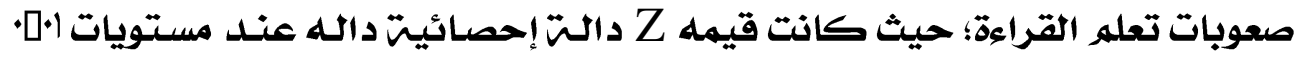

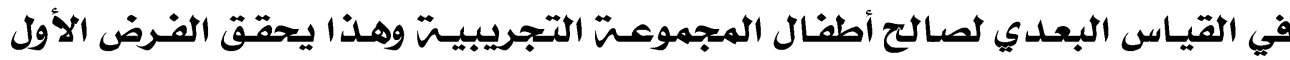
للد راست. نتائج الفرض الثاني: لاختبـارصتحت الفـرض الثاني للبحث واللذي يـص على:

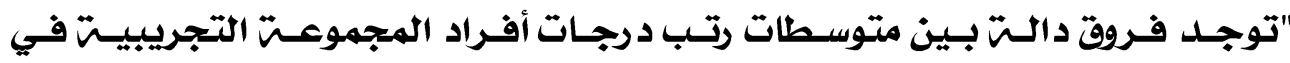

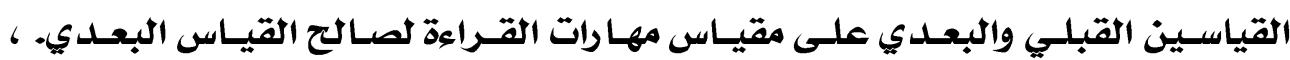

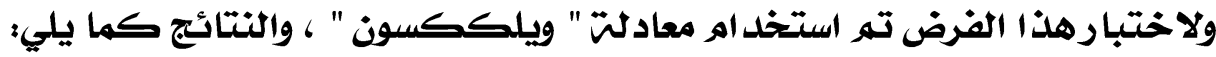

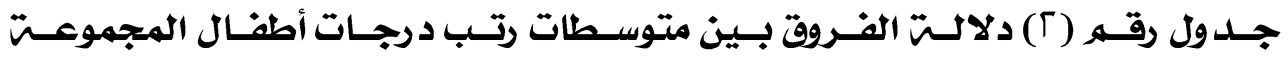

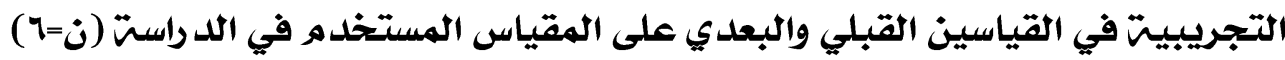




\begin{tabular}{|c|c|c|c|c|c|c|c|c|}
\hline اتلجاه & مستوى & قيمت & مجموع الرتب & متوسط الرتب & العدد | & قبلى/ بعدى القياس & | قرابعاد / & هر \\
\hline \multirow{3}{*}{ البعدى } & \multirow{3}{*}{$\because 0}$. & \multirow{3}{*}{$\Gamma, 50$} & 10 & $r . \Delta$ & $\Delta$ & السالبت & \multirow{3}{*}{ 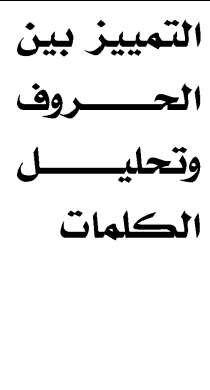 } & \multirow[t]{3}{*}{1} \\
\hline & & & • & • & • & الروتب & & \\
\hline & & & & & 1 & المتعادلت & & \\
\hline \multirow{3}{*}{ البعدى } & \multirow{3}{*}{.0 .05} & \multirow{3}{*}{$\Gamma, \mathrm{Fr}^{\mu}$} & $\Gamma$ & $r . \Delta$ & 7 & الرتبت & \multirow{3}{*}{ 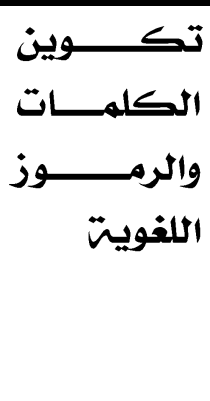 } & \multirow[t]{3}{*}{$\Gamma$} \\
\hline & & & • & . & - & الروتب & & \\
\hline & & & & & & المتعادلث & & \\
\hline \multirow{3}{*}{ البعدى } & \multirow{3}{*}{.0 .05} & \multirow{3}{*}{ Г. $\mathrm{TV}$} & 10 & 3.5 & 0 & الرتبت & \multirow{3}{*}{ 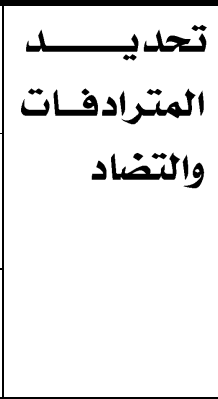 } & \multirow[t]{3}{*}{$\mu$} \\
\hline & & & • & , & - & الموجبت الرتب & & \\
\hline & & & & & 1 & المتعادلث & & \\
\hline \multirow{3}{*}{ البعدى } & \multirow{3}{*}{.0 .05} & \multirow{3}{*}{$\Gamma, \Gamma \cdot$} & $\Gamma$ & r.o & 7 & السالبت & \multirow{3}{*}{ الســــــــــــــــاق } & \multirow[t]{3}{*}{$\varphi$} \\
\hline & & & . & • & - & الموجبت & & \\
\hline & & & & & - & المتعادلت & & \\
\hline \multirow{2}{*}{ البعدى } & \multirow{2}{*}{.0 .05} & \multirow{2}{*}{$\Gamma . \Gamma 1$} & 21 & 3.5 & 6 & الرالبت & \multirow{2}{*}{ الافكــــــــاصـار } & 0 \\
\hline & & & 0 & 0 & 0 & الموجبت & & \\
\hline
\end{tabular}




\begin{tabular}{|c|c|c|c|c|c|c|c|c|}
\hline الدجاه & مستوى & قيمت & مجموع الرتب & متوسط الرتب & العلدد & قبلى/ بعدى & قابعادة الابع & هر \\
\hline & & & & & 0 & المتعادتب & & \\
\hline \multirow{3}{*}{ البعدى } & \multirow{3}{*}{.0 .05} & \multirow{3}{*}{$\Gamma, \Gamma \cdot$} & 21 & 3.5 & 0 & السالبت & \multirow{3}{*}{ 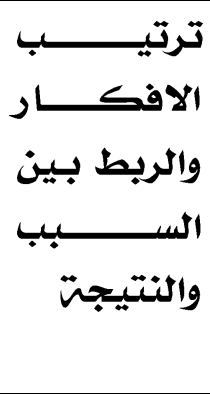 } & 9 \\
\hline & & & 0 & 0 & 0 & الموجبت & & \\
\hline & & & & & 1 & المتعادلت الرتب & & \\
\hline \multirow{3}{*}{ البعدى } & \multirow{3}{*}{.0 .05} & \multirow{3}{*}{$\Gamma, 5 \cdot$} & 21 & 3.5 & 6 & السالبت & \multirow{3}{*}{ 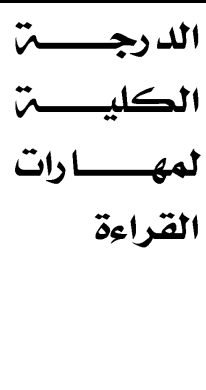 } & \\
\hline & & & 0 & 0 & 0 & الموجبتر & & \\
\hline & & & & & 0 & المتعادتب & & \\
\hline
\end{tabular}

يتضح من الجدول السابق وجود فروق دالتة إحصائيا بين متوسطات رتب درجـات افراد المجموعت التجريبيتت في كل من القياسين القبلي والبعلدي على مقياس مهارات

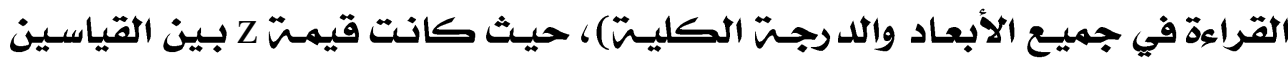

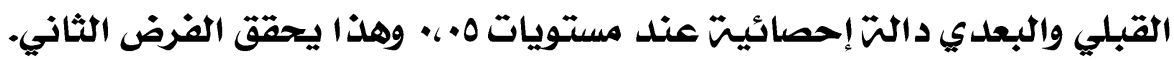

نتائج وتفسير الفرض الثالث: لاختبار صحتم الفرض الثالث للبحث والذي ينص على: "توجد فروق دالت بين متوسطات رتب درجـات أفراد المجمـوعتين التجريبيـت

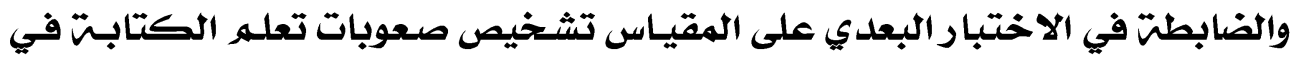
اتجاه المجموعت التجريبيت"ا.

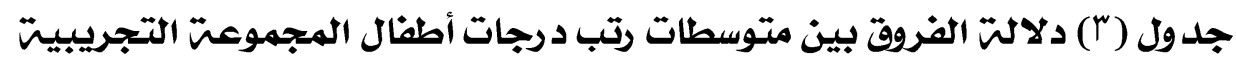
ومتوسطات درجات المجموعت الضابطت في القياس البعدي البوني

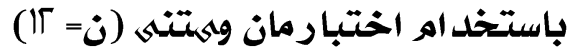

\begin{tabular}{|c|c|c|c|c|c|c|c|c|}
\hline $\begin{array}{l}\sum_{\alpha} \\
\underline{\underline{E}} \\
\underline{E}\end{array}$ & $\begin{array}{ll}\sum_{1} & G \\
\alpha & \sigma_{1} \\
\underline{E} & =\end{array}$ & $\underbrace{N}_{t:}$ & $\begin{array}{ll}E \\
E \\
\underline{E}\end{array}$ & $\underline{E}$ & $\underline{E}$ & $\because \underline{\underline{b}}$ & 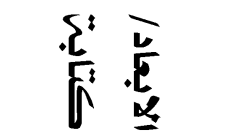 & \\
\hline التجريبيتت & $\because 0$ & $\Gamma . \Delta \mathrm{VI}$ & $\Gamma \Delta$ & 9.15 & 7 & الضابطت & التـرتيـــــــبـ & 1 \\
\hline
\end{tabular}




\begin{tabular}{|c|c|c|c|c|c|c|c|c|}
\hline $\begin{array}{l}\sum_{2} \cdot \vec{L} \\
\underline{E}\end{array}$ & $\begin{array}{ll}\sum_{0} & G \\
\vdots & E \\
E & E\end{array}$ & $\sum_{t:}^{N}$ & $\underline{E}: \xi$ & $\underline{E} \underline{E}$ & $\frac{2}{5}$ & $\circ:$ & 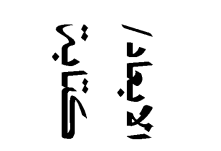 & \\
\hline & & & $\Gamma V$ & $\mu^{\mu} . \Delta{ }^{\mu}$ & 7 & التجريبيتن & والاكمال & \\
\hline \multirow{2}{*}{ التجريبيت } & \multirow{2}{*}{.6 .0} & \multirow{2}{*}{$\Gamma . \Delta \Gamma$} & 07.0 & 9.45 & 9 & الضابطت & \multirow[t]{2}{*}{ التنوين } & \multirow[t]{2}{*}{$\Gamma$} \\
\hline & & & $\Gamma 1.0$ & $r . \Delta A$ & 7 & التجريبيتت & & \\
\hline \multirow[t]{2}{*}{ التجريبيتت } & \multirow[b]{2}{*}{$\cdot 6 \cdot 1$} & \multirow[b]{2}{*}{ r.97 } & 07 & $9.5{ }^{\mu}$ & 7 & الضابطت & \multirow{2}{*}{ 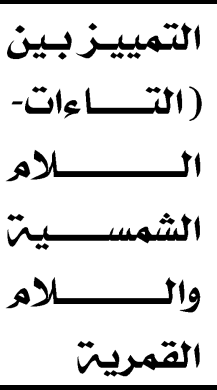 } & \multirow[t]{2}{*}{$r$} \\
\hline & & & एг & r.VT & 7 & التجريبيت & & \\
\hline \multirow[t]{2}{*}{ التجريبيت } & \multirow{2}{*}{0.01} & \multirow{2}{*}{ T.ANT } & $\Delta V$ & 9.0 & 7 & الضابطت & \multirow{2}{*}{ والمفرد } & \multirow[t]{2}{*}{$p$} \\
\hline & & & $\Gamma 1$ & $r_{6} \Delta^{\circ}$ & 9 & التجريبيت & & \\
\hline \multirow[t]{2}{*}{ التجريبيتت } & \multirow{2}{*}{0.01} & \multirow{2}{*}{$\Gamma .9 \cdot \Lambda$} & 57 & 9.50 & 7 & الضابطت & \multirow{2}{*}{ 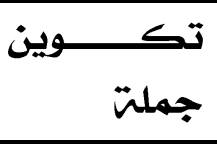 } & \multirow[t]{2}{*}{$\Delta$} \\
\hline & & & 21 & 3.50 & 7 & التجريبيتت & & \\
\hline \multirow[t]{2}{*}{ التجريبيتت } & \multirow{2}{*}{0.01} & \multirow{2}{*}{$\Gamma, \Delta \mathrm{VI}$} & 57 & 9.50 & 7 & الضابطت & \multirow{2}{*}{ فقرة } & \multirow[t]{2}{*}{4} \\
\hline & & & 21 & 3.50 & 7 & التجريبيت & & \\
\hline \multirow[t]{2}{*}{ التجريبيتت } & \multirow[b]{2}{*}{0.01} & \multirow[b]{2}{*}{ Г.वाг } & 57 & 9.50 & 7 & الضابطت & \multirow{2}{*}{ 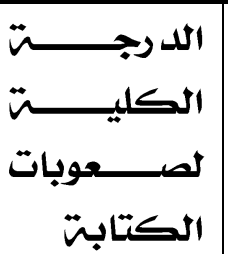 } & \\
\hline & & & 21 & 3.50 & 7 & التجريبيت & & \\
\hline
\end{tabular}

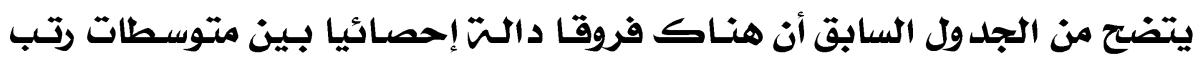

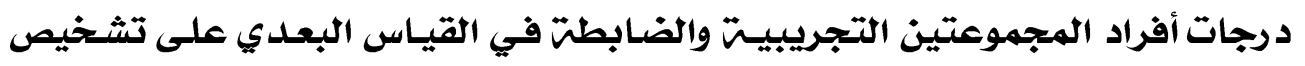

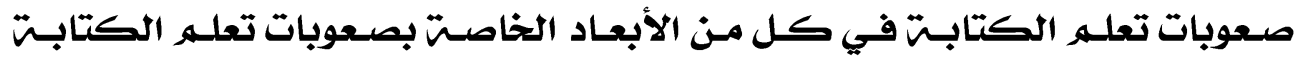

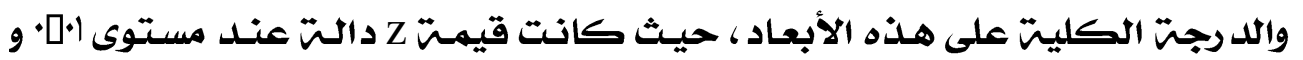

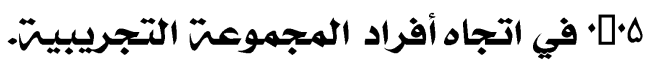

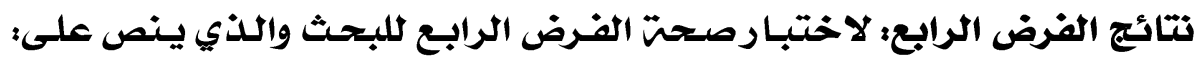

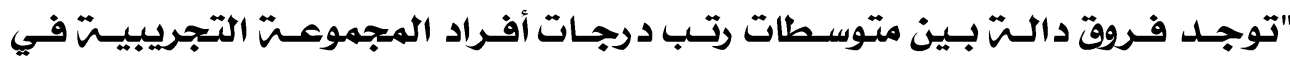

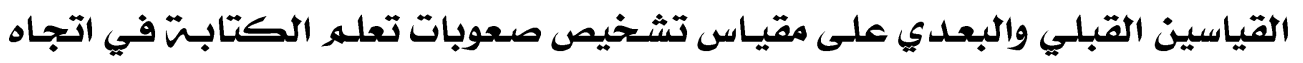

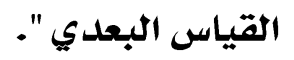




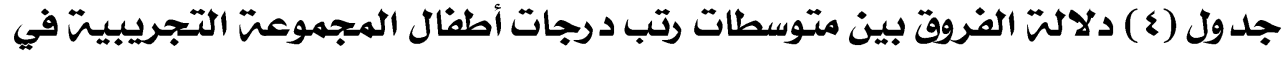

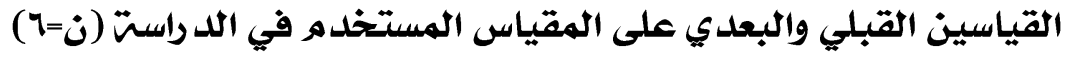

\begin{tabular}{|c|c|c|c|c|c|c|c|c|}
\hline $\begin{array}{l}L_{2} \\
\underline{E} \\
\underline{E}\end{array}$ & $\begin{array}{ll}\sum_{2} & E \\
E & E \\
E\end{array}$ & $\underbrace{N}_{b:}$ & $\begin{array}{ll}E & C \\
\underline{E} & 0 \\
\end{array}$ & $\underline{E}: \frac{E}{E}$ & $\underline{E}$ & $\frac{5}{E} \bar{E}$ & $\begin{array}{cc}c^{2} & \bar{k} \\
\mathfrak{k}^{2} & \underline{\underline{L}}\end{array}$ & ¿ \\
\hline \multirow{3}{*}{ البعدى } & \multirow{3}{*}{$\because \Delta$} & \multirow{3}{*}{$\Gamma . \Gamma^{\mu}$} & 21 & 3.5 & 6 & الرتب السالبت & \multirow{3}{*}{ 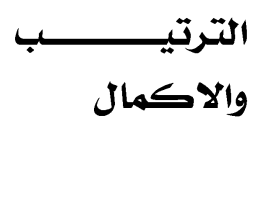 } & \multirow[t]{3}{*}{1} \\
\hline & & & . & . & • & الرتب الموجبت & & \\
\hline & & & & & $\cdot$ & الرتب المتعادلت & & \\
\hline \multirow{3}{*}{ البعدى } & \multirow{3}{*}{.. .0} & \multirow{3}{*}{ r. Fr } & M & r.O & 9 & الرتب السالبت & \multirow[t]{3}{*}{ التتوين } & \multirow[t]{3}{*}{$\Gamma$} \\
\hline & & & . & . & . & الرتب الموجبت & & \\
\hline & & & & & . & الرتب المتعادلت & & \\
\hline \multirow{3}{*}{ البعدى } & \multirow{3}{*}{$\cdot . \cdot 0$} & \multirow{3}{*}{$\Gamma . \Gamma \mathrm{V}$} & 10 & r.O & 0 & الرتب السالبت & \multirow{3}{*}{ 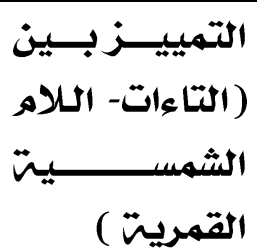 } & \multirow[t]{3}{*}{$\mu$} \\
\hline & & & - & • & - & الرتب الموجبت & & \\
\hline & & & & & . & الرتب المتعادلت & & \\
\hline \multirow{3}{*}{ البعدى } & \multirow{3}{*}{.6 .0} & \multirow{3}{*}{$\Gamma . \Gamma^{\mu}$} & 21 & 3.5 & 6 & الرتب السالبت & \multirow[t]{3}{*}{ الجمع والمفرد } & \multirow[t]{3}{*}{$\varphi$} \\
\hline & & & 0 & 0 & 0 & الرتب الموجبت & & \\
\hline & & & & & 0 & الرتب المتعادلت & & \\
\hline \multirow{3}{*}{ البعدى } & \multirow{3}{*}{.6 .0} & \multirow{3}{*}{$\Gamma . \Gamma \cdot$} & 21 & 3 & 5 & الرتب السالبت & \multirow[t]{3}{*}{ تكوين جملت } & \multirow[t]{3}{*}{$\Delta$} \\
\hline & & & - & - & - & الرتب الموجبت & & \\
\hline & & & & & 1 & الرتب المتعادلت & & \\
\hline \multirow{3}{*}{ البعدى } & \multirow{3}{*}{.6 .0} & \multirow{3}{*}{ Г. } & 15 & 3.5 & 6 & الرتب السالبت & \multirow[t]{3}{*}{ تكوين فقرة } & \multirow[t]{3}{*}{9} \\
\hline & & & & & & الرتب الموجبت & & \\
\hline & & & & & - & الرتب المتعادلت & & \\
\hline \multirow{3}{*}{ البعدى } & \multirow{3}{*}{$\cdot 6 \cdot 0$} & \multirow{3}{*}{$\Gamma . \Gamma^{\mu}$} & 15 & 3.5 & 6 & الرتب السالبت & الد رجت & \\
\hline & & & & & & الرتب الموجبت & الكليت & \\
\hline & & & & & • & الرتب المتعادلت & الصعوبات & \\
\hline
\end{tabular}


يتضح من الجدول السابق وجود فروق دالت إحصائيت عند مستويات (0•، ) بين

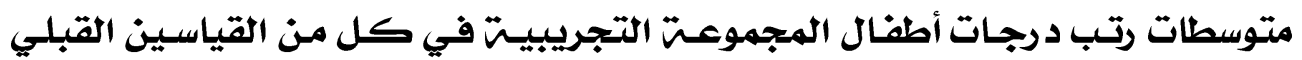

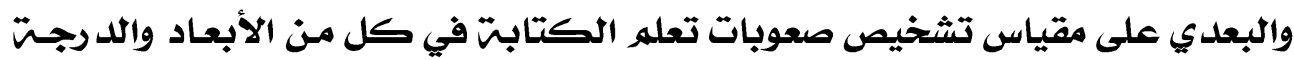
الكليت للمقياس، وهذا يحقق الفرض الرابع للدراست.

نتائج الفرض الخامس: لاختبارصحت الفرض الخامس للبحث والذي ينص على:

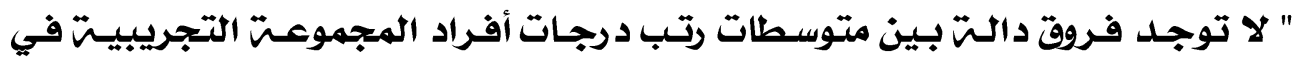

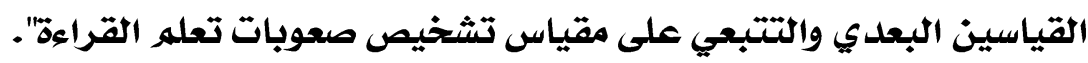

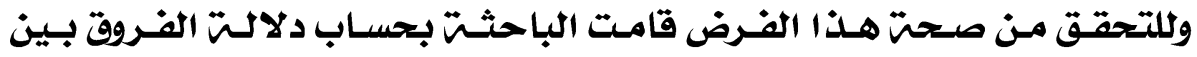

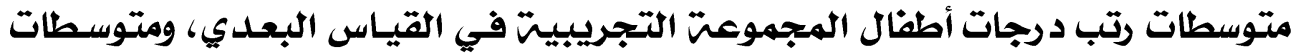

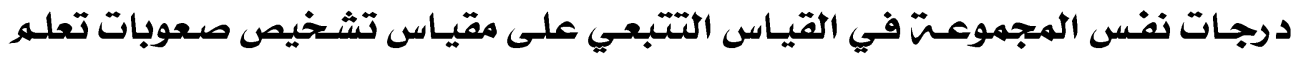

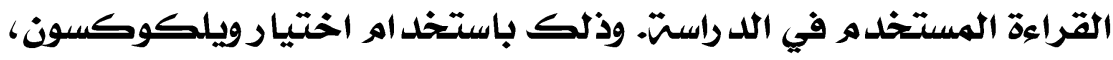

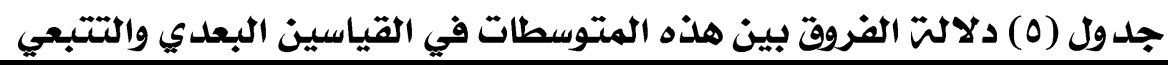

\begin{tabular}{|c|c|c|c|c|c|c|c|}
\hline الدال الداه & قيمت & مجموع الرتب & | الرتب & العدد & القياس بعدىى/ & |لابعاد/ & ه \\
\hline \multirow{3}{*}{ غير دال } & \multirow{3}{*}{1,4} & 1 & 1 & 1 & الرتب السالبت & \multirow{3}{*}{ التمييز بين } & \multirow{3}{*}{1} \\
\hline & & г & г & 1 & الرتب الموجبت & & \\
\hline & & & & q & الرتب المتعادلت & & \\
\hline \multirow{3}{*}{ غير دال } & \multirow{3}{*}{$1 . \varepsilon 1 \xi$} & r & 1.0 & r & الرتب السالبت & \multirow{3}{*}{ الكالموين } & \multirow{3}{*}{$\Gamma$} \\
\hline & & - & - & - & الرتب الموجبت & & \\
\hline & & & & $\varepsilon$ & الرتب المتعادلتة & & \\
\hline \multirow{3}{*}{ غير دال } & \multirow{3}{*}{$1.7 \cdot \varepsilon$} & 3 & 1.5 & 2 & الرتب السالبت & \multirow{3}{*}{ تحتديد } & \multirow{3}{*}{ r } \\
\hline & & 0 & 0 & 0 & الرتب الموجبت & & \\
\hline & & & & 4 & الرتب المتعادلت & & \\
\hline \multirow{3}{*}{ غير دال } & \multirow{3}{*}{ •، $\leqslant \leqslant V$} & 1 & 1 & 1 & الرتب السالبت & \multirow{3}{*}{ الستخداه } & \multirow{3}{*}{ r } \\
\hline & & $\Gamma$ & $\Gamma$ & 1 & الرتب الموجبت & & \\
\hline & & & & $\varepsilon$ & الرتب المتعادلت & & \\
\hline غير دال & $1.5 \varepsilon$ & r & 1.0 & $r$ & الرتب السالبت & استخخلاص & $\Delta$ \\
\hline
\end{tabular}




\begin{tabular}{|c|c|c|c|c|c|c|c|}
\hline الدلاهله & قيهت & مجموع الرتب & متوسط & العلدد & القياس بعدى/ & الابعاد / قراءة & 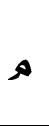 \\
\hline & & - & - & - & الرتب الهوجبت & الاكيكار الريستر & \\
\hline & & & & $\varepsilon$ & الرتب المتعادلت & والجزئيتيت & \\
\hline \multirow{3}{*}{ غير دال } & \multirow{3}{*}{1.81} & 3 & 1.5 & 2 & الرتب السالبت & \multirow{3}{*}{ والرافكار } & \multirow{3}{*}{9} \\
\hline & & 0 & 0 & 0 & الرتب الموجبت & & \\
\hline & & & & 4 & الرتب المتعادلث & & \\
\hline \multirow{3}{*}{ غير دال } & \multirow{3}{*}{$1.7 \cdot 8$} & 7 & $r$ & $r$ & الرتب السالبت & \multirow{3}{*}{ 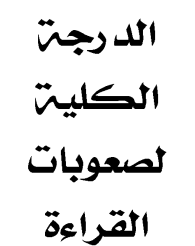 } & \\
\hline & & - & - & - & الرتب الموجبت & & \\
\hline & & & & $r$ & الرتب المتعادلت & & \\
\hline
\end{tabular}

يتضح من الجدول السابق عده وجود فروق بين متوسطات رتب درجـات أطفال

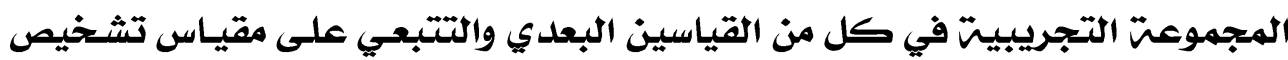

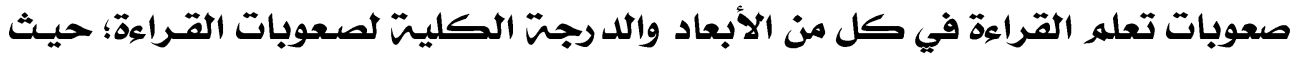

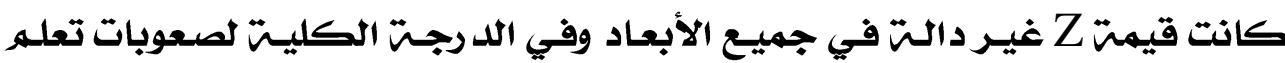
القراءة، وهذا يحقق الفرض الخامس.

تتائج الفرض السادس: لاختبارصحت الفرض السادس للبحث والذي ينص على:

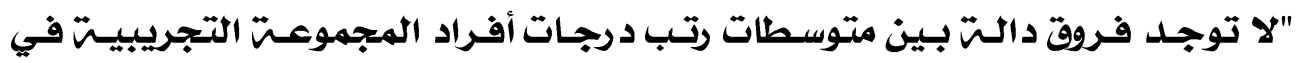

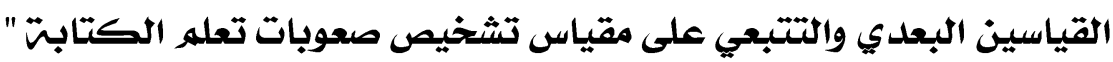

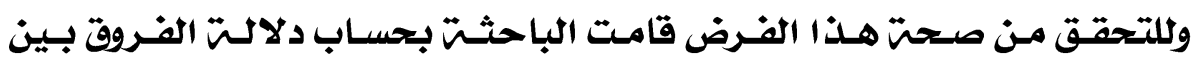

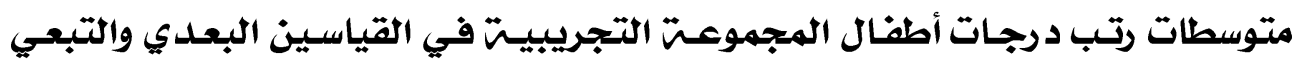

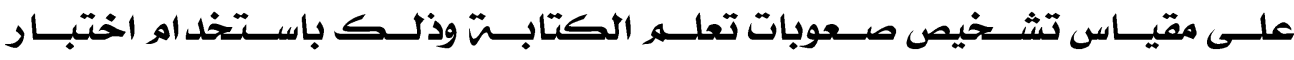

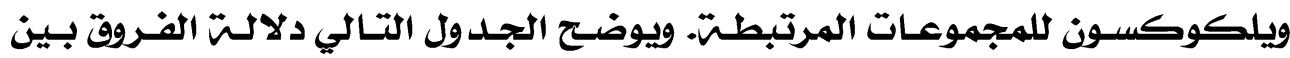
متوسطات رتب درجات تلاميذ المجموعت التجريبييت في القياسين البعدي والتبعي. 


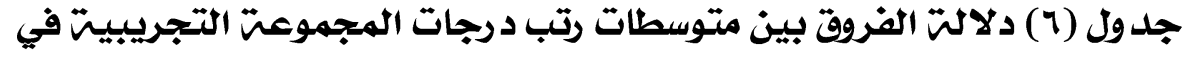
القياس البعلدي ومتوسطات رتب درجات نفس المجموعت في القولئ القياس التبعي على

\begin{tabular}{|c|c|c|c|c|c|c|c|}
\hline الدجاهل اتله & قيمت & مجموع الرتب & متوسط & العدد & القياس قبلى/ بعدى & |لابعاد/ & 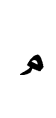 \\
\hline \multirow{3}{*}{ غير } & \multirow{3}{*}{$1.9 \%$} & 9 & $\Gamma$ & $r$ & الرتب السالبتت & \multirow{3}{*}{ والاكمال } & \multirow{3}{*}{1} \\
\hline & & . & • & • & الموجبت & & \\
\hline & & & & $r$ & المتعادثب & & \\
\hline \multirow{3}{*}{ غير } & \multirow{3}{*}{ :. } & 3.50 & r.o. & 1 & الرتب السالبت & \multirow{3}{*}{ التنوين } & \multirow{3}{*}{$\Gamma$} \\
\hline & & 2.50 & $1 . \mathrm{VO}$ & r & الموجبت & & \\
\hline & & & & $r$ & المتعادتب & & \\
\hline \multirow{3}{*}{ غير } & \multirow{3}{*}{. TVY } & 3.50 & r.o. & 1 & الرتب السالبت & \multirow{3}{*}{ التمييز بين } & \multirow{3}{*}{$\mu$} \\
\hline & & 2.50 & $1 . V 0$ & $r$ & الموجبت الرتبت & & \\
\hline & & & & $r$ & المتعادلث & & \\
\hline \multirow{3}{*}{ غير } & \multirow{3}{*}{ •GTrY } & 3.50 & 2.50 & 1 & الرتب السالبت & \multirow{3}{*}{ والمفرد } & \multirow{3}{*}{$\varphi$} \\
\hline & & 2.50 & 1.75 & r & الموجبت & & \\
\hline & & & & $r$ & المتعادلث & & \\
\hline \multirow{3}{*}{ غير } & \multirow{3}{*}{$1.9 \%$} & 7 & $r$ & $r$ & الرتب السالبت & \multirow{3}{*}{ تكوين } & \\
\hline & & - & - & - & الرجب & & $\Delta$ \\
\hline & & & & $r$ & الرتب & & \\
\hline
\end{tabular}




\begin{tabular}{|c|c|c|c|c|c|c|c|}
\hline الدلادله & قيمت & مجموع الرتب & متوسط الرتب & العلدد & القياس قبلى/ بعلى & الابعاد/ كتابت & 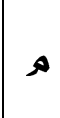 \\
\hline & & & & & المتعادلت & & \\
\hline \multirow{3}{*}{ غير } & \multirow{3}{*}{. ГVГ } & r.O. & 2.50 & 1 & الرتب السالبت & \multirow{3}{*}{ تكوين فقرة } & \\
\hline & & r.o. & 1.75 & $r$ & الهوجبت الرتب & & 9 \\
\hline & & & & $r$ & المتعادلث & & \\
\hline \multirow{3}{*}{ غير } & \multirow{3}{*}{ •NIS } & $\varepsilon .0$. & r.ro & $r$ & الرتب السالبت & \multirow{3}{*}{ الصعوبات الصليتت الصتابت } & \\
\hline & & 1.0. & 1.0. & 1 & الروجبت & & \\
\hline & & & & $r$ & المتعادثب & & \\
\hline
\end{tabular}

يتضح من الجدول السابق علده وجود فروق بين متوسطات رتب درجـات أطفال

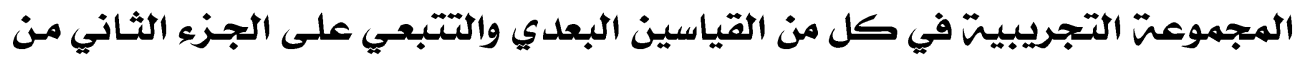

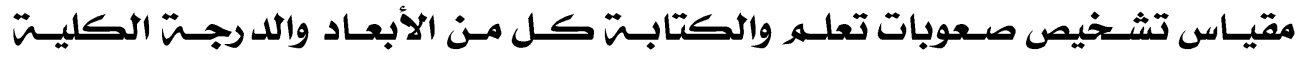

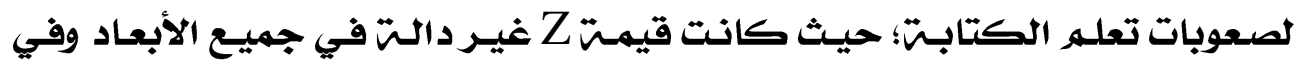

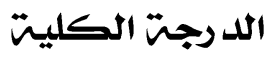

مناقشت وتفسير نتائج البحث:

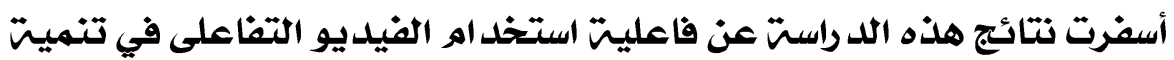

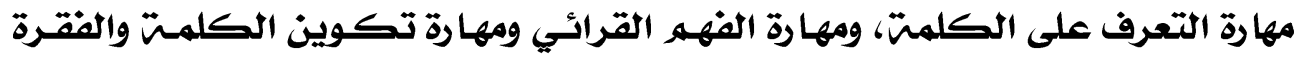

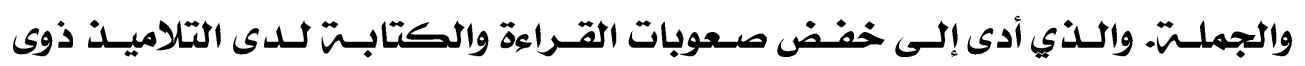

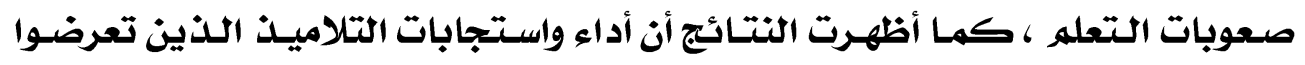

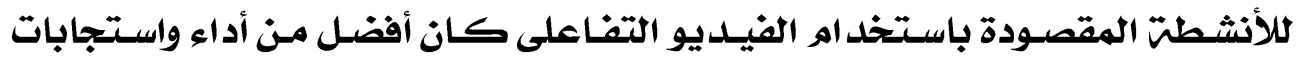

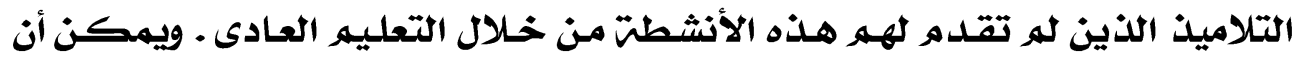

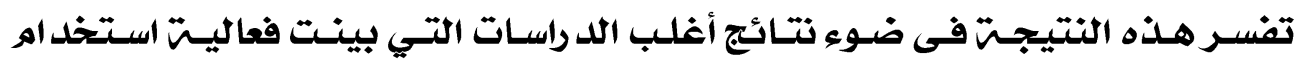

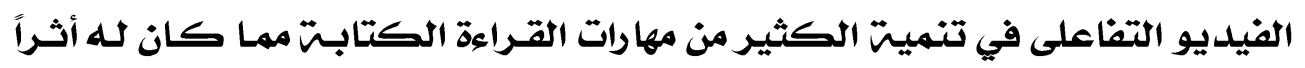

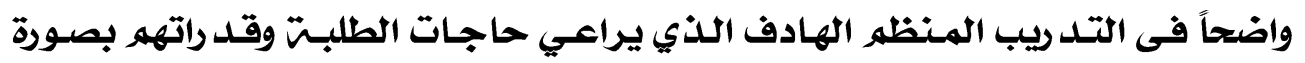

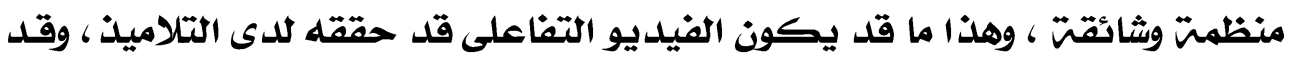

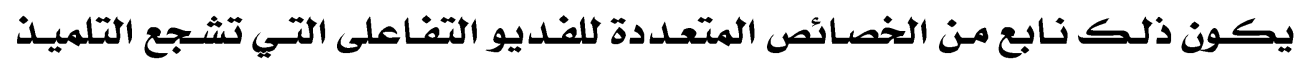




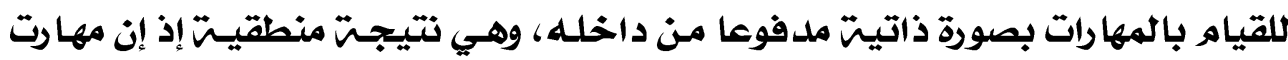

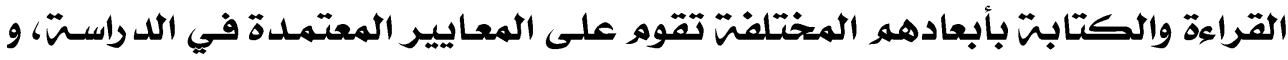

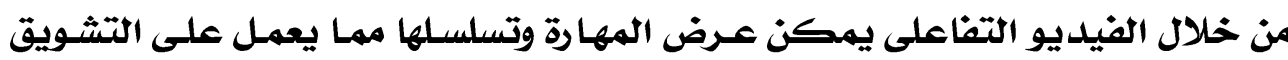
والانجذاب نحو التعله مع دور معله المادة في التوجيه والإنثراف.

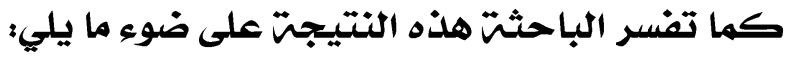

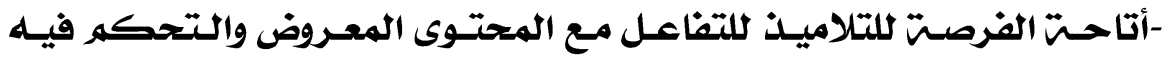

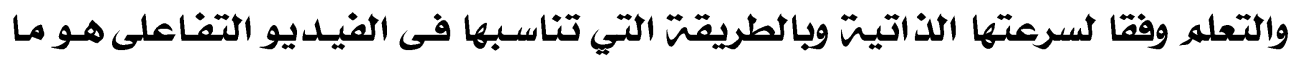
ساعدهم على اكتساب مهارات القراءة والكتابت المستهدفيته.

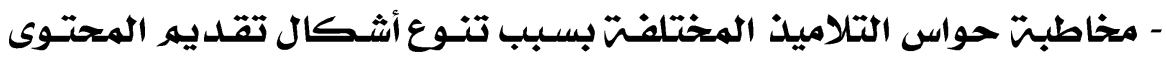

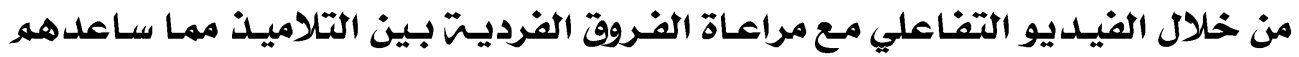

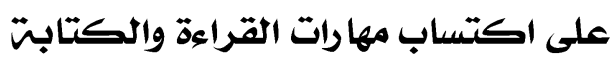

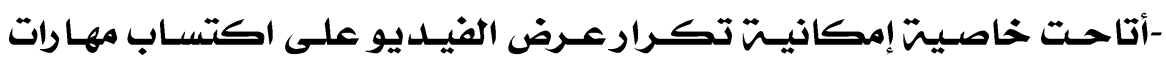

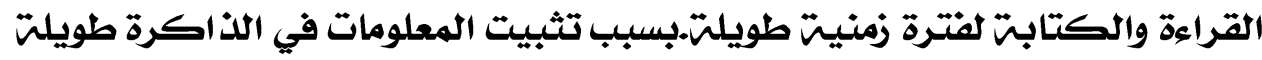

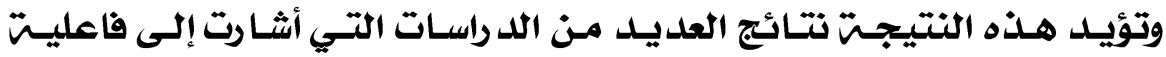

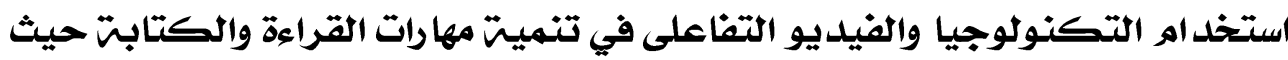

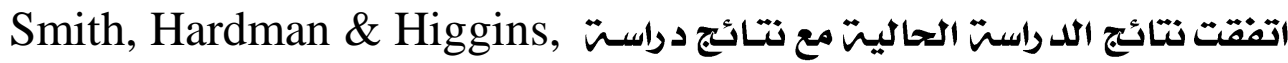

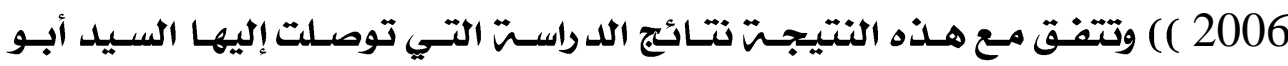

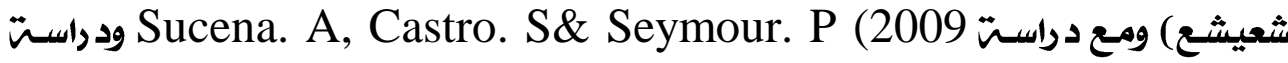

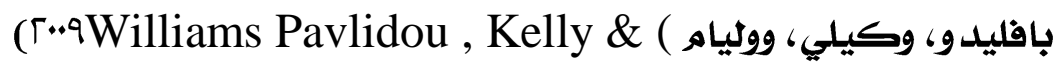

$$
\text { توصيات البحث: }
$$

في ضوء نتائج البحث الحالى يمكن تقديهر مجموعت من التوصيات تتمثل فيما يلي:

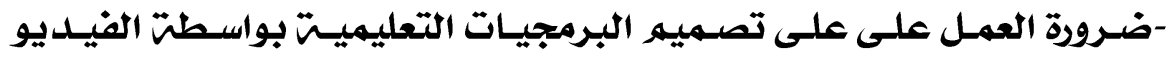

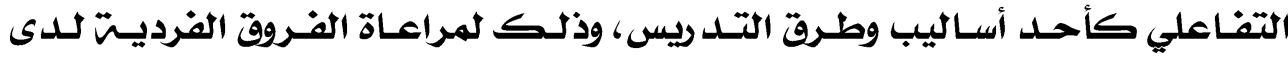

التلاميذ عند تنميت مهارات القراءة والكتابت لدى تلاميذ المرحلت التهل الابتد ائيت .

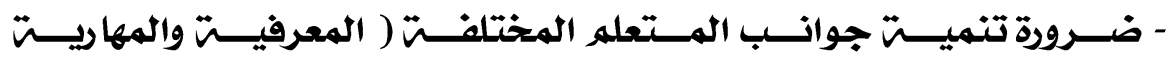

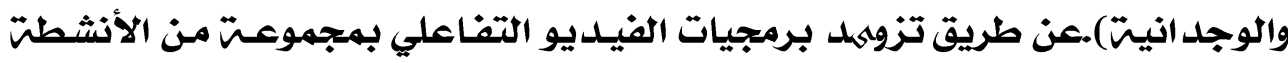
الهادفت

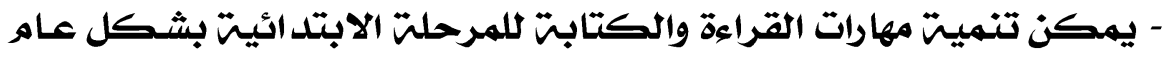

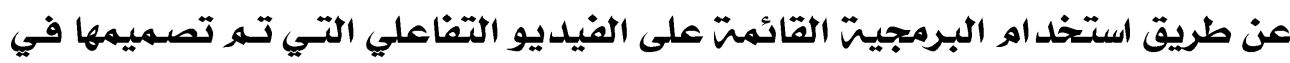
هذه الد راست هنيق 


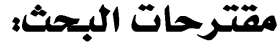

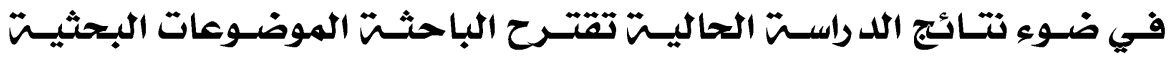

$$
\begin{aligned}
& \text { التاليت: }
\end{aligned}
$$

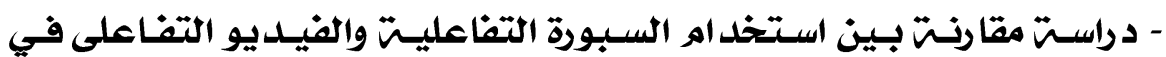

$$
\begin{aligned}
& \text { علاج صعوبات القراءة والكتابت لدى تلاميذ المرحلت الابتد ائيت. }
\end{aligned}
$$

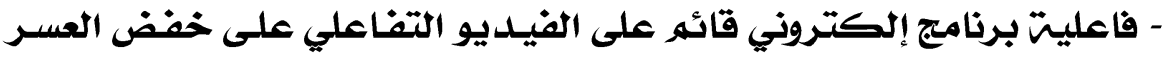

$$
\begin{aligned}
& \text { القرائى لدى تلاميذ ذوى صعوبات التعله • }
\end{aligned}
$$




\section{المراجع}

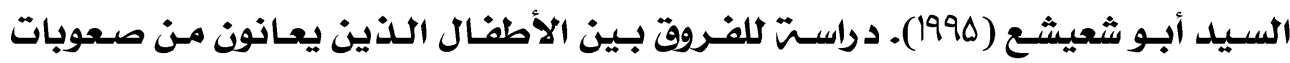

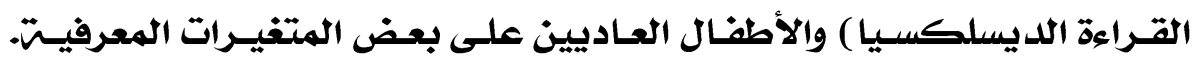

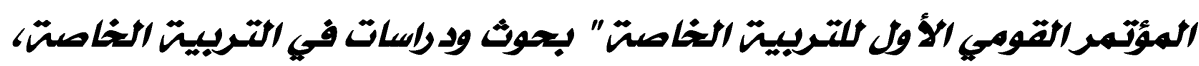

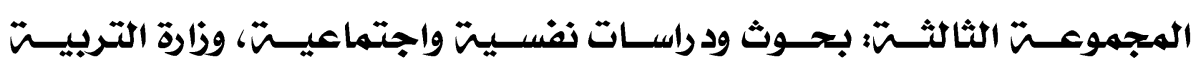

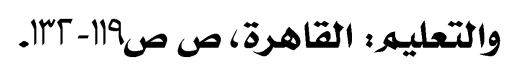

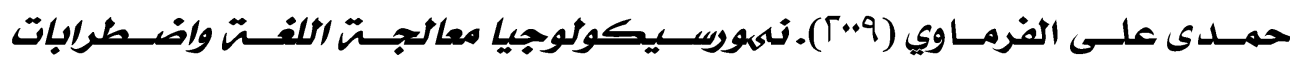

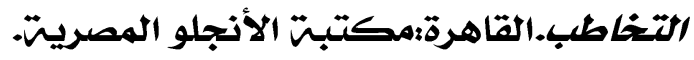

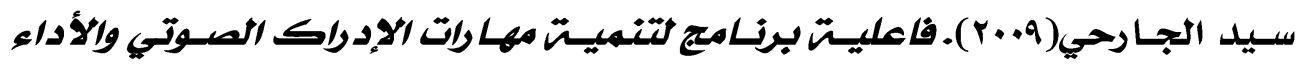

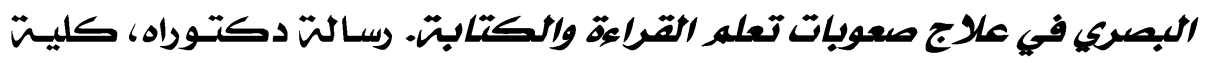
التربيتت، جامعت عين شمس.

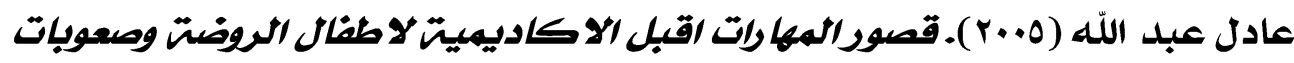

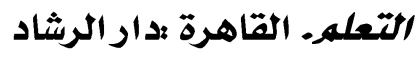

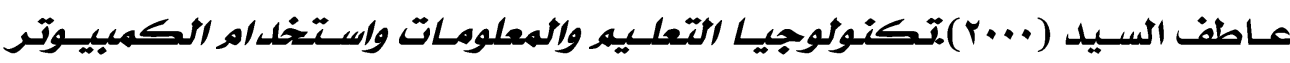

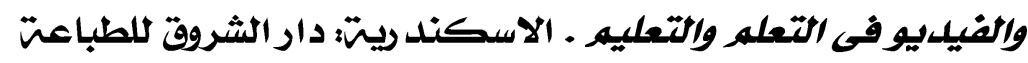

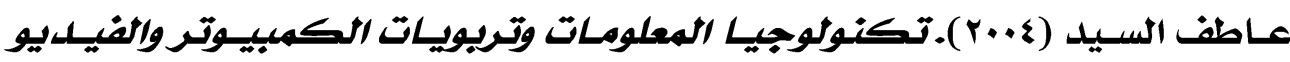

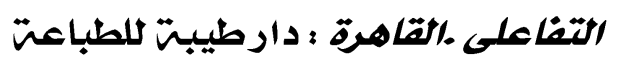

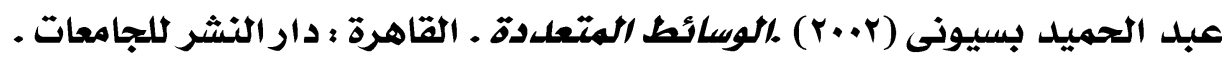

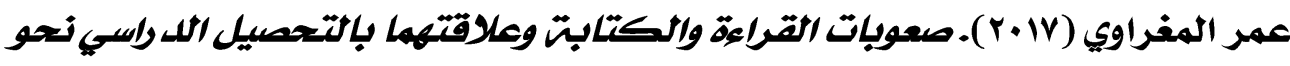

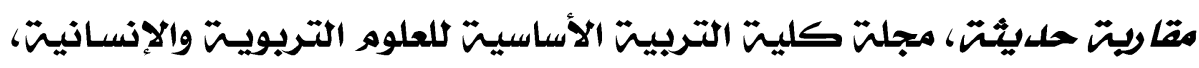

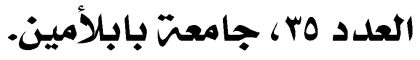

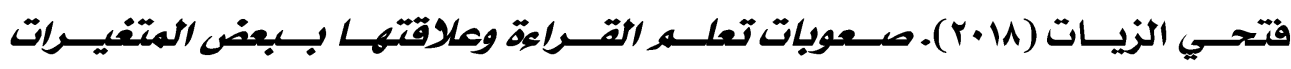

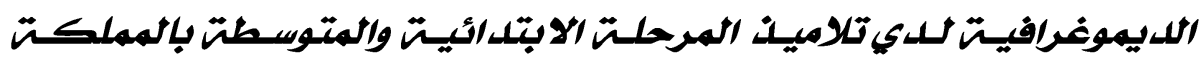

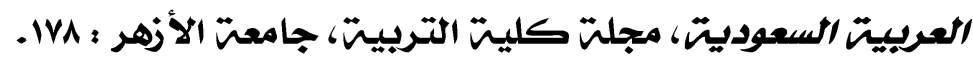

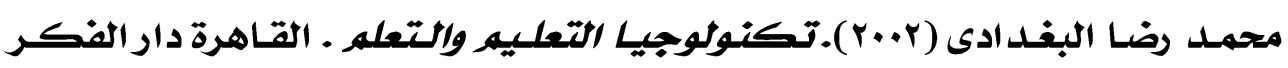

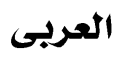

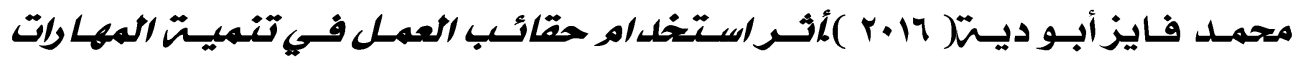

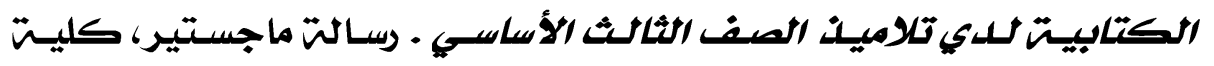

$$
\text { التربيتة، الجامعت الاسلاميتته }
$$

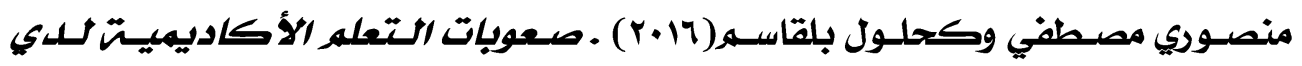

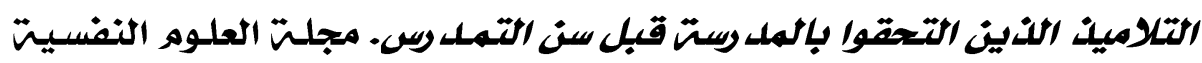

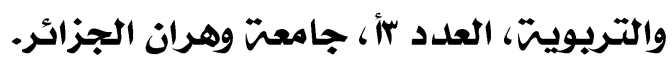




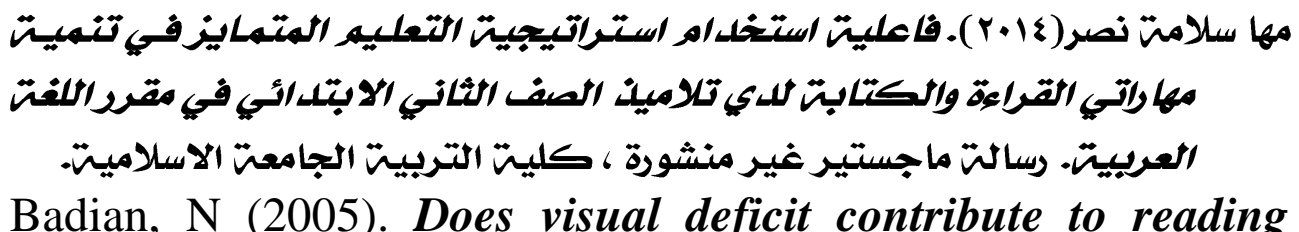
disability?,Journal of Dyslexia. 1(55),pp 28-52.

Chard. D \& Dickson. (1999). Phonological awareness: Instructional and assessment guide lines. Intervention in school and Clinic. 34 (5), p261.

Elizabeth, C. Nelson,E.(2009). Creative use of podcasting in higher education and its effect on competitive agency. Computers\& Education. 1(52), pp27-34.

Horan ،G. ( 2005). The effectiveness of interactive video using educational games in the acquisition of scientific concepts related to the composition of the human brain ،Educational Technology ،12 (25).pp $59-74$.

Jordan Education Initiative (2010).Promethean interactive videos in the discovery school retrieved, February 2, 2016om:http://jei.org.jo/Portals/0/Reports/2010/Promethean \%20-20Final\%20Report.pdf.

Lin, Y.(2010). The study of learning effects and attitude of using interactive video into unit of writeing for fourth graders with different academic achievements .(master's thesis),chaina, retrieved, February 2, 2016 from: ttp://onlinelibrary.wiley.com/doi/10.1111/j.1365-

2729.2005.00118.x/full

Martin. S (2007). Interactive video and talking books: A new approach to teaching children to write. Journal of Literacy, 41(1), $53-65$

Michal,T.(1995). Evaluating teaching programs for children with Specific learning . Remedial Education. (.2).1, PP.2027.

Mohammadian, A, Saed, A\& Shahi, Y(2018) .The Effect of Using Video Technology on Improving Reading Comprehension of Iranian .Intermediate EFL Learners Advances in Language and Literary Studies, (9) ,2.P P17-23 
Pavildou. E, Killy. L \& Williams (2009). Artificial grammar learning in primary school children with and without developmental dyslexia. Annual of Dyslexia, Springer; Published on line March.

Smith, F .Hardman, F.\& Higgins, s.(2006). The impact of interactive videos on teacher - pupil interaction in national literacy and numeracy strategies, British Education Research Journal, 32(3),PP433-457.

Sucena. A, Castro. S\& Seymour. P (2009). Developmental dyslexia in orthography of intermediate depth: The case study of European Portuguese. Read Write, Springer: Published on line January.

Turel,Y. k.,\&Johnson,T.E.(2012).Teacher belief and use of interactive whiteboards for. teaching and learning .Educational Technology \&Society, 15(1),381-394

William. T \& James. C (2003). The Reading Recovery Approach to preventive early intervention: As good as it gets?. New York: Taylor \& Francis Inc

Zittle .F.J.(2004). Enhancing Native American Mathematics Learning: The Use of Smartboard-generated Virtual Manipulatives for Conceptual Understanding, retrieved, February 2, 2016 from: 